\title{
Survey of Waste Package \\ Designs for Disposal of High-Level Waste/Spent Fuel in Selected Foreign Countries
}
K. J. Schneider
D. J. Silviera
L. T. Lakey

September 1989

Prepared for the U.S. Department of Energy under Contract DE-AC06-76RLO 1830

Pacific Northwest Laboratory Operated for the U.S. Department of Energy by Battelle Memorial Institute 


\title{
DISCLAIMER
}

This program was prepared as an account of work sponsored by an agency of the United States Government. Neither the United States Government nor any agency thereof, nor Battelle Memorial Institute, nor any or their employees, makes any warranty, expressed or implied, or assumes any legal liability or responsibility for the accuracy, completeness, or usefulness of any information, apparatus, product, or process disclosed, or represents that its use would not infringe privately owned rights. Reference herein to any specific commercial product, process, or service by trade name, trademark, manufacturer, or otherwise, does not necessarily constitute or imply its endorsement, recommendation, or favoring by the United States Government of any agency thereof, or Battelle Memorial Institute. The views and opinions of authors expressed herein do not necessarily state or reflect those of the United States Government or any agency thereof.

\author{
PACIFIC NORTHWEST LABORATORY \\ operated by \\ BATTELLE MEMORIAL INSTITUTE \\ for the \\ UNITED STATES DEPARTMENT OF ENERGY \\ under Contract DE-AC06-76RLO 1830
}

Printed in the United States of America

Available to DOE and DOE contractors from the

Office of Scientific and Technical information, P.O. Box 62, Oak Ridge, TN 37837;

prices available from (615) 576-8401. FTS 626-8401.

Available to the pubtic from the National Technical Information Service, U.S. Department of Commerce, 5285 Port Royal Rd., Springfield, VA 22161.

NTIS Price Cudes, Microtiche A01

\begin{tabular}{cc}
\multicolumn{2}{c}{ Printed Copy } \\
& $\begin{array}{c}\text { Price } \\
\text { Codes }\end{array}$ \\
$\frac{\text { Pages }}{001-025}$ & A02 \\
$026-050$ & A03 \\
$051-075$ & A04 \\
$076-100$ & A05 \\
$101-125$ & A06 \\
$126-150$ & A07 \\
$151-175$ & A08 \\
$176-200$ & A09 \\
$201-225$ & A10 \\
$226-250$ & A11 \\
$251-275$ & A12 \\
$276-300$ & A13
\end{tabular}


SURVEY OF WASTE PACKAGE DESIGNS FOR DISPOSAL OF HIGH-LEVEL WASTE/SPENT FUEL IN SELECTED FOREIGN COUNTRIES
K. J. Schneider
L. T. Lakey
D. J. Silviera

September 1989

Prepared for the U.S. Department of Energy under Contract DE-AC06-76RLO 1830

Pacific Northwest Laboratory Richland, Washington 99352 



\section{ABSTRACT}

This report presents the results of a survey of the waste package strategies for seven western countries with active nuclear power programs that are pursuing disposal of spent nuclear fuel or high-level wastes in deep geologic rock formations. Information, current as of January 1989, is given on the leading waste package concepts for Belgium, Canada, France, Federal Republic of Germany, Sweden, Switzerland, and the United Kingdom.

All but two of the countries surveyed (France and the U.K.) have developed design concepts for their repositories, but none of the countries has developed its final waste repository or package concept. Two countries have determined the host rock for their repositories (Belgium with clay, and Germany with salt); the others have yet to narrow their choice from several candidates. Candidate rocks in other countries are crystalline rocks (granite, gabbro, schist), salt, gneiss, clay, or anhydrite. Most of the countries plan to open their geologic repositories between the years 2010 and 2050 following aging times of 30 or more years. None of the countries surveyed is currently planning to include provisions for retrievability of the waste package before or after closure of the repository.

Waste package concepts are under study in ail the countries surveyed, except the U.K. Most of the countries have not yet developed a reference concept and are considering several concepts. Most of the information presented in this report is for the current reference or leading concepts. All countries that are reprocessing spent fuel are planning to vitrify their high-level waste as monolithic borosilicate glass. Canada and Sweden are the only countries surveyed that are not planning to reprocess their spent fuel. Germany plans to consolidate the rods of spent fuel that are considered to be non-reprocessable. Canada and Sweden are planning to incorporate their spent fuel within a matrix material of sand, and copper or lead, respectively.

All canisters for the wastes are cylindrical, and are made of metal (stainless steel, mild steel, titanium, or copper). The canister concepts have relatively thin walls, except those for spent fuel in Sweden and Germany. Diagrams are presented for the reference or leading concepts for 
canisters for the countries surveyed. The expected lifetimes of the conceptual canisters in their respective disposal environment are typically 500 to 1,000 years, with Sweden's copper canister expected to last as long as one million years. Overpack containers that would contain the canisters are being considered in some of the countries. All of the countries surveyed, except one (Germany) are currently planning to utilize a buffer material (typically bentonite) surrounding the disposal package in the repository. Most of the countries surveyed plan to limit the maximum temperature in the buffer material to about $100^{\circ} \mathrm{C}$. 


\section{BACKGROUND AND INTRODUCTION}

All countries with nuclear-powered generation of electricity must eventually dispose of their spent fuel or the high-level wastes (HLW) that are derived from reprocessing of their spent fuel. All countries surveyed are planning to dispose of their spent fuel/HLW in a deep geologic formation, from about 300 to 1200 meters below the earth's surface. Geologic disposal, along with the engineered barriers in the geologic disposal facility, is expected to provide isolation of the radionuclides in the wastes from man's environment for thousands of years.

In geologic disposal, the isolation of waste materials from man's environment relies on several barriers to prevent or retard the transport of radionuclides into man's environment. These barriers include: the durability of the waste form itself (e.g., spent fuel and its cladding, vitrified $H(W)$; the durability of the canister immediately surrounding the waste form, the durability of the disposal container (if any) surrounding the canister; the retardation of radionuclide transport due to any packing or buffer material between the waste canister or disposal container and the disposal hole or its liner; the retardation of radionuclide migration due to the geologic formation and its setting, and the retardation within the biosphere. For this report, all but the last two of these barriers are considered to be part of the waste package (as defined in the U.S.).

The host rock formation and the overall geologic setting are generally expected to provide the bulk of the long-term waste isolation (i.e., for the post disposal time periods after about 1,000 years and longer). However, the waste package is expected to provide the buik of the short-term isolation (i.e., up to about 1,000 years), when the radioactivity levels in the waste are the highest. As such, the waste package will play a significant role in the isolation of the wastes from man.

The waste package (or parts of it) will also provide short-term functions such as containment during interim storage of the wastes, handling and containment during transportation between and within waste management facilities. 
Because the waste package will be an important part of the waste disposal repository system for spent fuel and $H L W$, most countries with active repository development programs are carrying out programs on development and evaluation of waste packages. Reference waste package concepts have been defined by some countries, but final concepts have not yet been selected by any country. Reference concepts are those that are developed to serve as a guide for subsequent development, but significant changes in the concepts can occur before final implementation.

The objective of this survey is to provide an overview of waste package descriptions, designs and strategies being considered in the geologic disposal programs of selected foreign countries. This survey is to provide information for the U.S. Department of Energy's (DOE) Office of Civilian Radioactive Waste Management (OCRWM) for planning on technical exchange activities with foreign entities. Where avajlable, information is included on the rationale for designs and strategies, regulatory requirements, and waste package environment. Details of designs and supporting technical studies are not covered within the scope of this report. Countries covered are Belgium, Canada, France, Federal Republic of Germany (referred to as "Germany"), Sweden, Switzerland, and the United Kingdom (U.K.). These are the countries reviewed because they have currently, or have had in the recent past, the most active repository development programs.

This survey summarizes information available as of January 1989 (a) in the public literature and that obtained in discussions to date between foreign representatives and staff of DOE and/or the Pacific Northwest Laboratory's (PNL) International Program Support Office (IPSO) staff and foreign representatives. Changes in the available information can be expected to occur with time and the level of detail differs among the countries covered because of differences in the state of development of the

(a) This report takes into account the Federal Republic of Germany's decision made in May 1989 to abandon spent fuel reprocessing in their country and to contract their reprocessing to France and the United Kingdom. However, the decision does not affect their overall plans to reprocess the spent fuel, to dispose of high-level waste in a vitrified form, and the final waste form. 
programs, the number of major alternatives being pursued in some cases, and differences in the amounts of information available. Where information is not shown, it is generally because, to DOE's and IPSO's knowledge, the country has not carried out or published any major work on that subject area. A summary of the information for all of the countries covered is given in the Summary, along with overview figures of selected waste package concepts. This is followed by individual sections containing information for each country in alphabetical order. The information is given in brief, bulleted format for each country, using a common questionnaire-type outline (the questionnaire items are shown in bold). Where information is not applicable or available for certain major heading categories in the questionnaire (e.g., disposal container) for a given country, those headings are not repeated. The references for all sections follow the detailed information for the United Kingdom. Finally, a glossary is given for the terms as used in this report, based on U.S. usage and based primarily on definitions used for the U.S. Yucca Mountain Project. 



\section{SUMMARY}

This survey provides an overview of waste package development programs in seven foreign, western countries that are pursuing deep geologic disposal of spent nuclear fuel or high-level wastes. Information is given as of January 1989, but strategies and concepts will change with time. Some information desired in the survey was not available in most cases because the individual country has not yet carried out major activities in that area. Rationale for the decisions that have been made is given in the detailed sections for individual countries where it was available. Highlights of the major findings are presented in the text, figures and tables included in this summary.

\section{OVERALL STATUS OF WASTE REPOSITORY CONCEPTS}

A tabular summary of the status of the repository concepts in the countries surveyed is given in Table 1 . All of the seven countries are planning to build a deep geologic repository within their country boundaries. All but two of the countries (France and the U.K.) have developed design concepts for their repositories, but none of the countries has developed its final waste repository or package concept. France is in the early stages of repository concept development, and the U.K. is deferring that activity for a few more decades. The reference concepts for all countries involve emplacement of canisters in boreholes in the floors of mined tunnels (drifts) or emplacement directly in the mined tunnels. Only two of the countries (Belgium and Germany) have determined the host rock for their repositories, and the others have yet to narrow this choice from several possible rock types. Only one country (Germany) has selected a specific site to be characterized. All seven countries are locating their repositories below a water table.

Most of the countries surveyed plan to have their repository in operation between 2010 and about 2050. The date of the startup of the first repository (Germany) is planned to be about the year 2005. Canada and the U.K. do not plan to have their repositories until the year 2050 or beyond. 


\section{IABLE 1. Overall Status of Repository Concepts}

\begin{tabular}{|c|c|c|c|c|c|c|}
\hline Country & $\begin{array}{c}\text { Repository } \\
\text { Stutus }\end{array}$ & $\begin{array}{l}\text { Repository } \\
\text { Concept }\end{array}$ & Host Rock & $\begin{array}{l}\text { Repository } \\
\text { Startup, } \\
\text { Approx, year }\end{array}$ & $\begin{array}{c}\text { Package } \\
\text { Retrierability } \\
\text { Planned/Required } \\
\end{array}$ & $\begin{array}{l}\text { Underground } \\
\text { Research } \\
\text { Laboratory (UAL) }\end{array}$ \\
\hline Belgiun & $\begin{array}{l}\text { Conceptual foasi- } \\
\text { bility shom, site } \\
\text { selected }\end{array}$ & $\begin{array}{l}\text { Canisters in bore- } \\
\text { holes in tunnel } \\
\text { floors or in drifts }\end{array}$ & clay & 2025 & None planned & Ine in operation \\
\hline Canada & $\begin{array}{l}\text { Concepts being } \\
\text { ussessed }\end{array}$ & $\begin{array}{l}\text { Ref: Conisters in } \\
\text { boroholes in tunnel } \\
\text { floors; Alt: can- } \\
\text { isters in tunnels }\end{array}$ & $\begin{array}{l}\text { granite or } \\
\text { gabbro }\end{array}$ & $>206$ & $\begin{array}{l}\text { Mone noeded } \\
\text { af tor elosure }\end{array}$ & $\begin{array}{l}\text { UAt under } \\
\text { construction }\end{array}$ \\
\hline France & $\begin{array}{l}\text { Concepts not } \\
\text { ident if ied }\end{array}$ & $\begin{array}{l}\text { Concepts aro un- } \\
\text { der study }\end{array}$ & $\begin{array}{l}\text { clay, oranito, } \\
\text { achist or salt }\end{array}$ & 2010 & $\begin{array}{l}\text { Not yot } \\
\text { dec ided }\end{array}$ & Ure planned \\
\hline Goruany & $\begin{array}{l}\text { Concept } \\
\text { dereloped, aite } \\
\text { selected }\end{array}$ & $\begin{array}{l}\text { Ho in boreholes } \\
\text { in tunnel floors } \\
\text { and spent fuel in } \\
\text { tunnels }\end{array}$ & solt done & 2005 & no & (We in operation \\
\hline Sweden & $\begin{array}{l}\text { Reforence concept } \\
\text { develeped, seeking } \\
\text { sites }\end{array}$ & $\begin{array}{l}\text { Canisters in bora- } \\
\text { holes in tunnol } \\
\text { floors }\end{array}$ & $\begin{array}{l}\text { granite or } \\
\text { gnoiss }\end{array}$ & 2120 & Not noeded & Une planned \\
\hline $\begin{array}{l}\text { Switzor- } \\
\text { innd }\end{array}$ & $\begin{array}{l}\text { Roference concept } \\
\text { developed to con- } \\
\text { firn feacibility; } \\
\text { seaking aites }\end{array}$ & $\begin{array}{l}\text { Conistors in } \\
\text { tunnels }\end{array}$ & $\begin{array}{l}\text { cryetslline } \\
\text { rock, cloy or } \\
\text { onhydrite }\end{array}$ & 2016 & Hot needed & URe in operation \\
\hline U.K. & $\begin{array}{l}\text { Concepts consid- } \\
\text { ored early } 80 \text { 'a; } \\
\text { no ner activities } \\
\text { for }>50 \text { years }\end{array}$ & None yot & $\begin{array}{l}\text { granite, clay, } \\
\text { alit or } \\
\text { antrydrite }\end{array}$ & $\begin{array}{l}\text { probably } \\
\text { 22160 }\end{array}$ & $\begin{array}{l}\text { Mot yot } \\
\text { docided }\end{array}$ & $\begin{array}{l}\text { URe not planned } \\
\text { to bo built soon }\end{array}$ \\
\hline
\end{tabular}

Alt: - Alternative

Rof : - Reference 
The earlier startup dates are generally based on estimates of the time required to implement a repository program; the later dates are based on estimated times when a repository would be needed or when it is believed to be appropriate to have a repository. None of the seven countries is currently planning to include special provisions for retrievability of the waste package before or after closure of the repository. However, some of the repository concepts would facilitate retrieval. Because all of the countries are in the early stages of their repository development, no repository designs have been finalized, and likewise, their plans for waste packages have not been finalized.

\section{OVERALL STATUS OF WASTE PACKAGE CONCEPTS}

The overall status of the waste package concepts and the waste package components under development is sumarized in Table 2. Waste package concepts are under study in all the countries except the U.K. (which is carrying out generic waste package studies). Most of the countries have not yet developed a reference concept and are considering several concepts. Most of those countries with reference concepts are also considering alternative concepts. The most effort to date on development of the waste packages has been carried out in Sweden and in Germany for their direct disposal of spent fuel.

All the countries in this survey that are reprocessing spent fuel are planning to vitrify their waste as monolithic borosilicate glass. The only countries surveyed that are not currently planning to reprocess spent fuel are Sweden and Canada (but Canada is deferring the final decision). The Germans consider some of their spent fuel to be "unreprocessable" (e.g., from pebble bed reactors, once-through MOX fuel, perhaps some high burn-up fuel), and plan to dispose of these types of "non-standard" fuels directly as consolidated rods in packages, except for some of the fuels which would be impracticable to consolidate. Canada and Sweden do not plan to consolidate their spent fuel rods for direct disposal, but Germany does plan on consolidation. In Canada's reference disposal concept for spent fuel, the 
TABLE 2. Status of Waste Package Concepts and Components

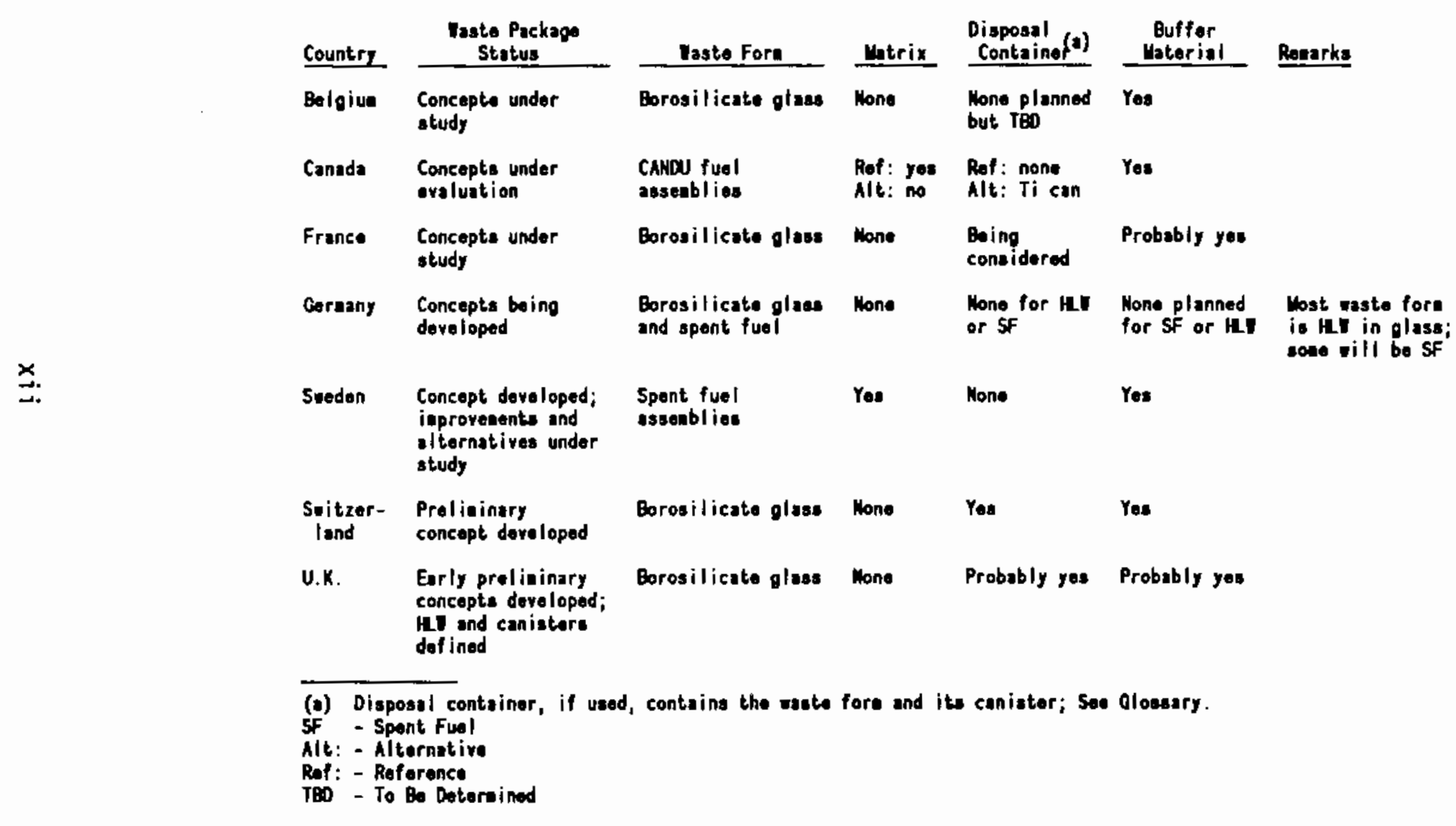


spent fuel is encapsulated in a sand matrix. Sweden's concept includes a metal matrix, while Germany's concept for spent fuel does not include encapsulation in a matrix.

Several of the countries have not yet decided if they will have a separate disposal container (a sealed overpack outside of the canister, see the Glossary). Sweden, Canada (in their reference concept), and Germany (for direct disposal of spent fuel) do not plan to use a disposal container but will use a long-lived canister. Also, Belgium is not planning to have a disposal container for its vitrified HLW canister. Switzerland is planning on having a disposal container. France, Canada (in an alternative concept), Germany (for vitrified $H L W$ ), and the U.K. are planning for or will consider the use of disposal containers. All the countries that have developed disposal concepts are planning to surround the canister, and where applicable, the disposal container with a buffer/packing material.

\section{OVERALL WASTE FORM AND CANISTER CHARACTERISTICS}

An overview of the conceptual waste form and canister characteristics for the seven countries is given in Table 3 . The out-of-reactor age of the waste at the time of encapsulation varies from possibly as short as one year (for France and the U.K. for reprocessing wastes) to a more typical range of 10 to about 40 years. The expected out-of-reactor age of the waste at the time of emplacement in a repository is generally 30 to 100 years. Monolithic borosilicate glass with a waste oxide content of 10 to 25 weight percent is the waste form for vitrified HLW because the processing step is well developed and the waste form is believed to be acceptable. Where the use of a matrix for encapsulation of spent fuel is planned, the matrix materials considered are lead, compacted copper powder or sand. Matrix materials, where used, are generally to provide structural support and/or shielding.

All canisters under consideration in current concepts are cylindrical, and consist of thin-walled stainless steel (Belgium, France, Germany, Switzerland and the U.K. for HLW), thin-walled titanium (Canada), thickwalled steel (Canada as an alternative, Germany for spent fuel [with 
IABLE 3. Characteristics of Reference Waste Forms and Canisters

\begin{tabular}{|c|c|c|c|c|c|c|}
\hline & Country & Daste Fore & $\begin{array}{l}\text { Apo of Taste } \\
\text { Thon Ercapsulated/ } \\
\text { Disposed, Years }\end{array}$ & $\begin{array}{l}\text { Yatrix } \\
\text { Hatorial }\end{array}$ & $\begin{array}{c}\text { Canister Material } \\
\text { Haterial Thickness }\end{array}$ & $\begin{array}{l}\text { Expected Life } \\
\text { of Canister } \\
\end{array}$ \\
\hline & Bolgiun & Borosilicato glass & $10-20 />50$ & None & SSt/6en froe France & $\begin{array}{l}\text { Through aplaco- } \\
\text { nent or ca. BI yrs }\end{array}$ \\
\hline & Canada & $\begin{array}{l}\text { CANDU SF } \\
\text { asseablios }\end{array}$ & $50-100 / 50-100$ & $\begin{array}{l}\text { Coapacted } \\
\text { aand; } \\
\text { Att: lead }\end{array}$ & 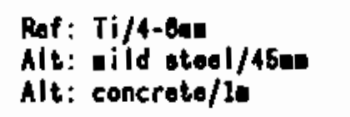 & $\begin{array}{l}\text { sol yrs aftor } \\
\text { onplacoment }\end{array}$ \\
\hline & France & Borosilicste glass & $1-5 / 34$ & Hone & SSt/5 at & $\begin{array}{l}\text { N/I; 1061 yra } \\
\text { for total pkg }\end{array}$ \\
\hline & Gorany & $\begin{array}{l}\text { Borosilicate glass, } \\
\text { and consolidated } \\
\text { SF rods }\end{array}$ & $\begin{array}{l}\text { hav: } 5-10 />10, \\
\text { SF: } 5-10 / 710\end{array}$ & Hone & $\begin{array}{l}\text { LL: SSt/5en } \\
\text { SF: steel/15eu, } \\
\text { coated } \mathbf{T} / \text { Hastol loy/8ne }\end{array}$ & 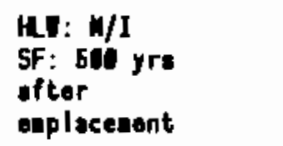 \\
\hline 套. & Sweden & SF assenblies & 41/40 & $\begin{array}{l}\text { Lead or } \\
\text { campacted } \\
\text { copper pooder }\end{array}$ & Copper/10cs & $1,00 t, 090$ yrs \\
\hline & $\begin{array}{l}\text { Seitzer- } \\
\text { land }\end{array}$ & Borosilicate glass & $11 / 40$ & Mono & SSt/6ue fron Frunce & $\begin{array}{l}\text { N/I but probably } \\
\text { through oncapsu- } \\
\text { lation in dis- } \\
\text { posal container }\end{array}$ \\
\hline & U. $\boldsymbol{k}$. & Borosilicate gloss & $1-20 / 60-160$ & Mone & SSt/5-6an & $\begin{array}{l}\text { W/I but probsbly } \\
\text { through oncapas- } \\
\text { lation in dis- } \\
\text { possl contsiner }\end{array}$ \\
\hline & $\begin{array}{l}\text { N/I }-N_{0} \\
\text { SF }=S_{p} \\
\text { Rof: }-R_{e} \\
\text { Alt: }-A I \\
\text { SSt }=S t\end{array}$ & $\begin{array}{l}\text { Inforastion ovailable } \\
\text { nt Fuol } \\
\text { erence } \\
\text { ernative } \\
\text { inless Steel }\end{array}$ & & & & \\
\hline
\end{tabular}


additional shielding from a disposable transportation packaging]), thickwalied copper (Sweden), and thick-walled concrete containers (Canada as an al ternative).

Expected lifetimes of the canisters, based on research and development to date, for Canada and Germany (for spent fuel), are 500 and 1,000 years, respectively; for Sweden's thick-walled copper canister it is 1,000,000 years. Sweden's disposal concept relies on the canister for a major part of isolation of the waste from the environment under expected conditions for the long term. Belgium currently plans on canisters to last only through emplacement in the repository. The inference for Switzerland and the U.K., and possibly for France, is that the canister needs to last only until encapsulation in a disposal container.

OVERVIEW OF DISPOSAL CONTAINER AND BUFFERS

The general plans to use buffer (or packing) materials and disposal containers in addition to the canister, are summarized in Table 4. In about half of the cases, the countries are currently planning to use the canisters as the disposal containers. Special features are incorporated into the canister design for this function, such as using thick-walled and/or corrosion-resistant canisters for structural strength (i.e., to withstand hydrostatic and lithostatic pressures) and/or corrosion resistance, or coating the canister with corrosion-resistant materials. In three countries (Belgium, France, and the U.K.), the use of discrete disposal containers is still to be determined. Although there is considerable uncertainty at this time on whether to use disposal containers, where disposal containers are being considered, a life expectancy in the range of 500 to 1000 years is anticipated.

Most of the countries are planning to use a buffer material around the canisters, or where applicable, around the disposal containers. The buffer materials are expected to retard water from reaching the emplaced containers, and to provide retardation of transport of radionuclides from breached 
TABLE 4. Characteristics of Reference Waste Disposal (overpacks) Containers and Buffer Materials

\begin{tabular}{|c|c|c|c|}
\hline Country & $\begin{array}{c}\text { Disposal } \\
\text { Contsiner(s) } \\
\text { Materisl/Thickness }\end{array}$ & $\begin{array}{c}\text { Expected } \\
\text { Lifo of Disposal } \\
\text { Container(a) yesrs } \\
\end{array}$ & $\begin{array}{l}\text { Buffor Material } \\
\text { Churacteristics }\end{array}$ \\
\hline Bolgiue & $\begin{array}{l}\text { Hone planned } \\
\text { but } T \notin 0\end{array}$ & $\begin{array}{l}\text { Not deterained until } \\
\text { decision on need for } \\
\text { disposal container } \\
\text { is esde }\end{array}$ & $\begin{array}{l}\text { Buffer vill bo host clay } \\
\text { backfill; for disposal } \\
\text { borehole concept, sand } \\
\text { vill surround the } \\
\text { canister }\end{array}$ \\
\hline Canads & $\begin{array}{l}\text { Ref: no contsiner } \\
\text { Alt: Ti/4-Ben }\end{array}$ & $\begin{array}{l}\text { Rof: not applicablo } \\
\text { Alt: 5ot yrs }\end{array}$ & Compacted clay-ond \\
\hline Frence & Boing considered & If used, ca. 19at & $\begin{array}{l}\text { Clays are being ectively } \\
\text { invest ipated }\end{array}$ \\
\hline Cornany & $\begin{array}{l}\text { Mo disposal contuiner } \\
\text { for hill or spent fuel }\end{array}$ & Not applicablo & $\begin{array}{l}\text { None (use excevated } \\
\text { crushed selt) }\end{array}$ \\
\hline Sweden & Wo disposa / container & Not applicable & $\begin{array}{l}\text { Conpacted bentonite } \\
\text { blocks }\end{array}$ \\
\hline $\begin{array}{l}\text { Sritzer- } \\
\text { land }\end{array}$ & Cast steol/25en & Ca. $149 t$ & $\begin{array}{l}\text { Compacted bantonite } \\
\text { block }\end{array}$ \\
\hline U. $\mathbf{k}$. & $\begin{array}{l}\text { Dill dopend on diaposal } \\
\text { onvironment; considering } \\
\text { thin } \mathrm{Ti} \text {, Hastelloy or } \\
\text { thick cast steol }\end{array}$ & 6as-1es: & $\begin{array}{l}\text { Considering bentonite } \\
\text { or caeont }\end{array}$ \\
\hline
\end{tabular}

(a) Dispos*l container, if used, contains the wate for and its conister; sea Glosury. TBD - To to Daterained 
containers into the groundwater. In all cases, the buffer material selected is clay or clay-rock mixtures. The U.K. is also considering the use of cement.

\section{DIAGRAMS OF WASTE PACKAGE CONCEPTS}

Diagrams that show the overall features of the reference waste packages and their respective emplacement configurations are presented in the nine figures that follow. Diagrams for the canisters used in all the seven countries are shown. Diagrams for the emplacement configurations for France and the U.K. are not included, because no reference configurations are yet available.

Figure 1 shows the canister for vitrified HLW that is currently used in France, and is planned for use in the U.K. when their vitrification facilities are operating. These canisters will also be used for vitrified HLW that has been returned to Germany, Belgium and Switzerland from one of the reprocessing plants in France and the U.K.

Figure 2 shows two potential Belgian configurations for emplacement of vitrified HLW canisters in drifts in clay, and Figure 3 shows an alternative Belgian configuration for emplacement in boreholes projecting outward at 45 degree angles from an emplacement drift in clay.

Figure 4 shows the reference Canadian canister for intact CANDU spent fuel assemblies, and the reference emplacement configuration in granite.

Figure 5 shows the reference German Pollux canister/cask for direct disposal of consolidated LWR spent fuel. Figure 6 presents the German disposal configuration for vitrified HLW in deep boreholes from the bottom of emplacement drifts, and for spent fuel in Pollux canisters/casks in emplacement drifts, both in salt.

Figure 7 shows the reference and alternative Swedish canister for intact spent fuel, and Figure 8 presents the reference Swedish emplacement configuration for those canisters in granite.

Figure 9 shows the reference Swiss disposal container for vitrified HLW, and the reference emplacement configuration in drifts in granite. 


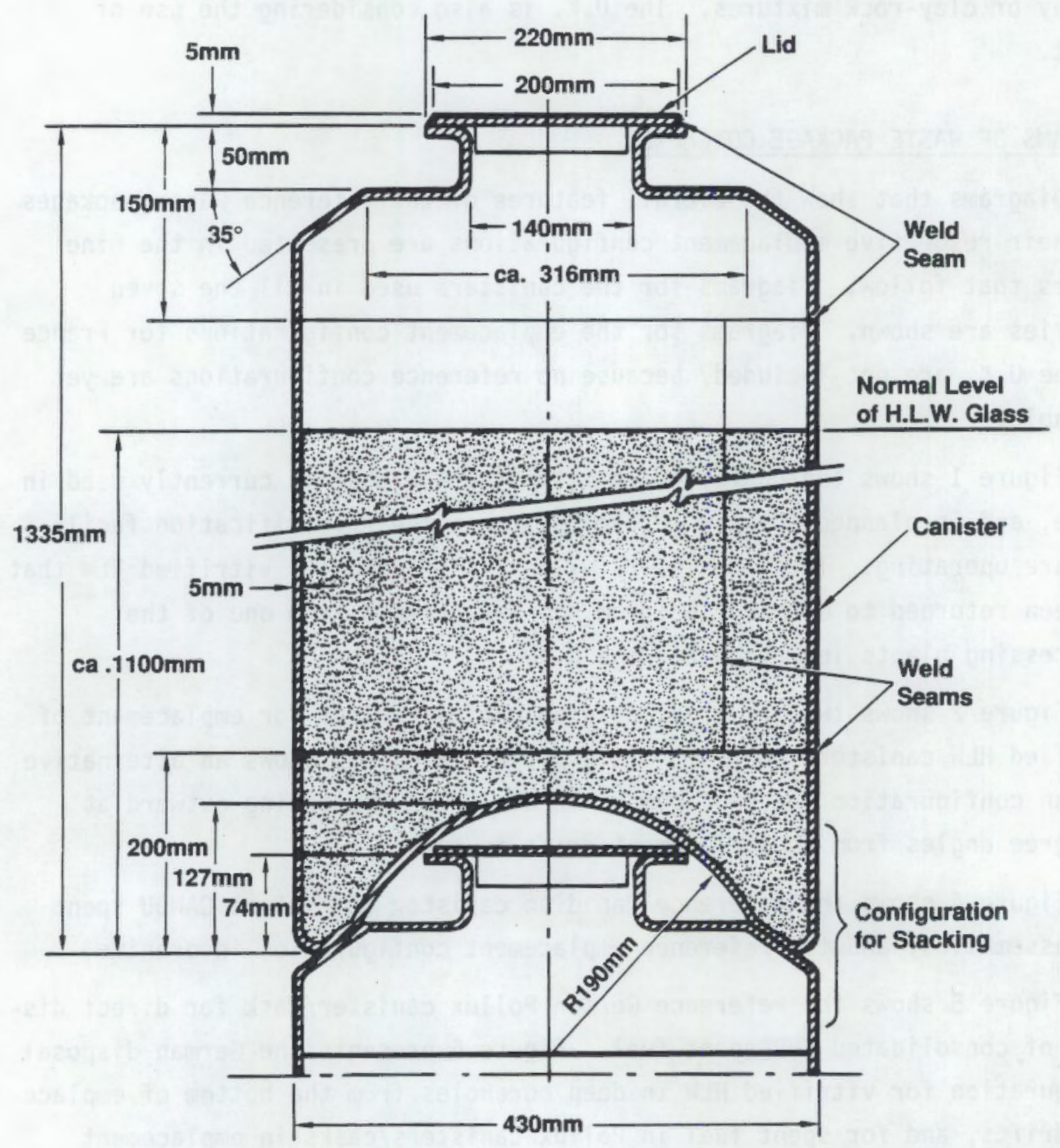

Empty Weight: ca. 75 kg

Material: Stainless Steel

Max. Head Rate: ca. 2.4 kW

Taken from German KfK Drawing

Filled Weight: ca. $473 \mathrm{~kg}$

Gross Volume: 180 liters

Max. Activity: $499,000 \mathrm{Cl}$

Glass Volume: 150 liters

H.L.W. from 1.15-1.31 MTU

FIGURE 1. French, German and U.K. Canister for Vitrified HLW (also used for Belgian and Swiss HLW) 


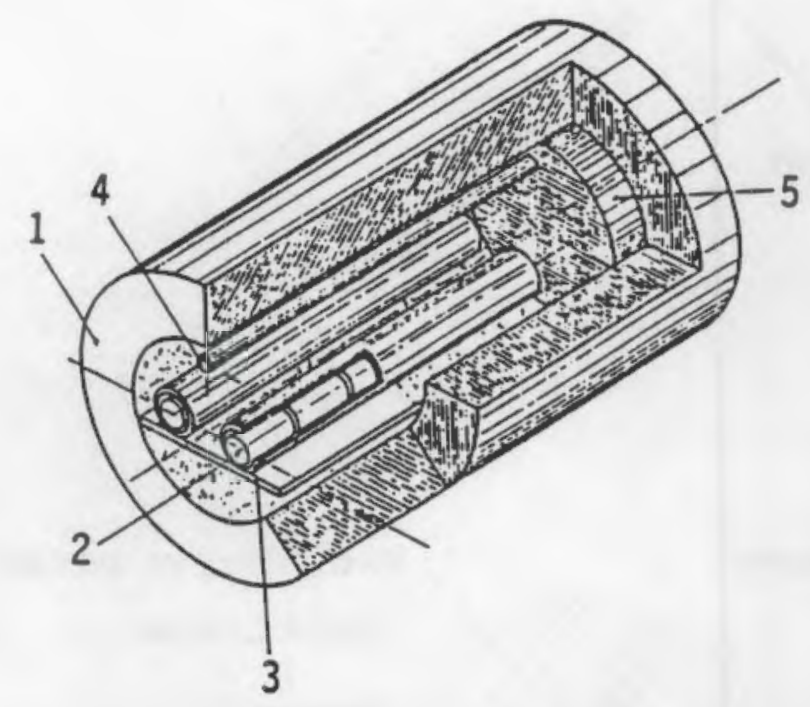

1 TUNNEL LINING

2 HLW CANISTER

3 GUIDE FRAME

4 BACKFILL INJECTION TUBE

5 BACKFILL (CONCRETE)

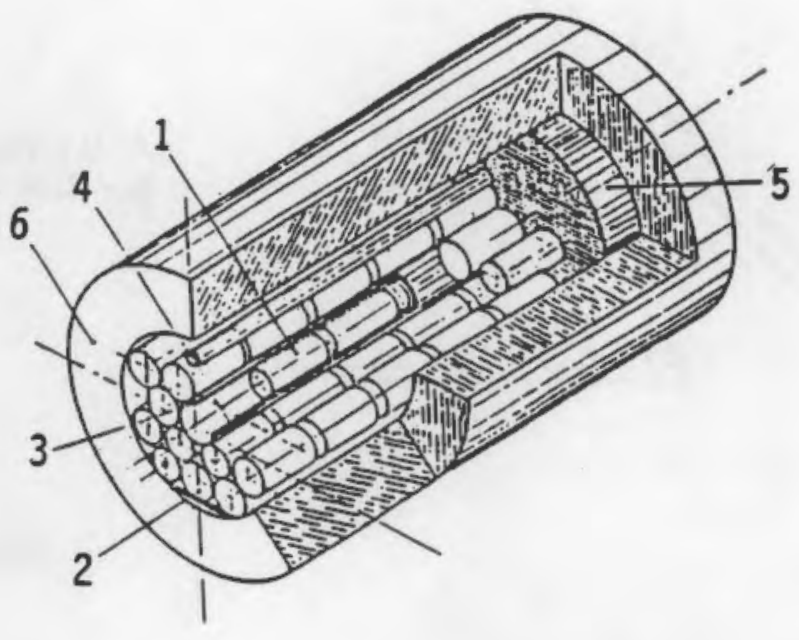

1 HLW CANISTER

2 ILW DRUMS

3 GUIDE FRAME

4 BACKFILL INJECTION TUBE

5 BACKFILL (CONCRETE)

6 TUNNEL LINING

FIGURE 2. The Two Belgian Concepts for Disposal of Canisters of Vitrified HLW in Drifts in Clay. 

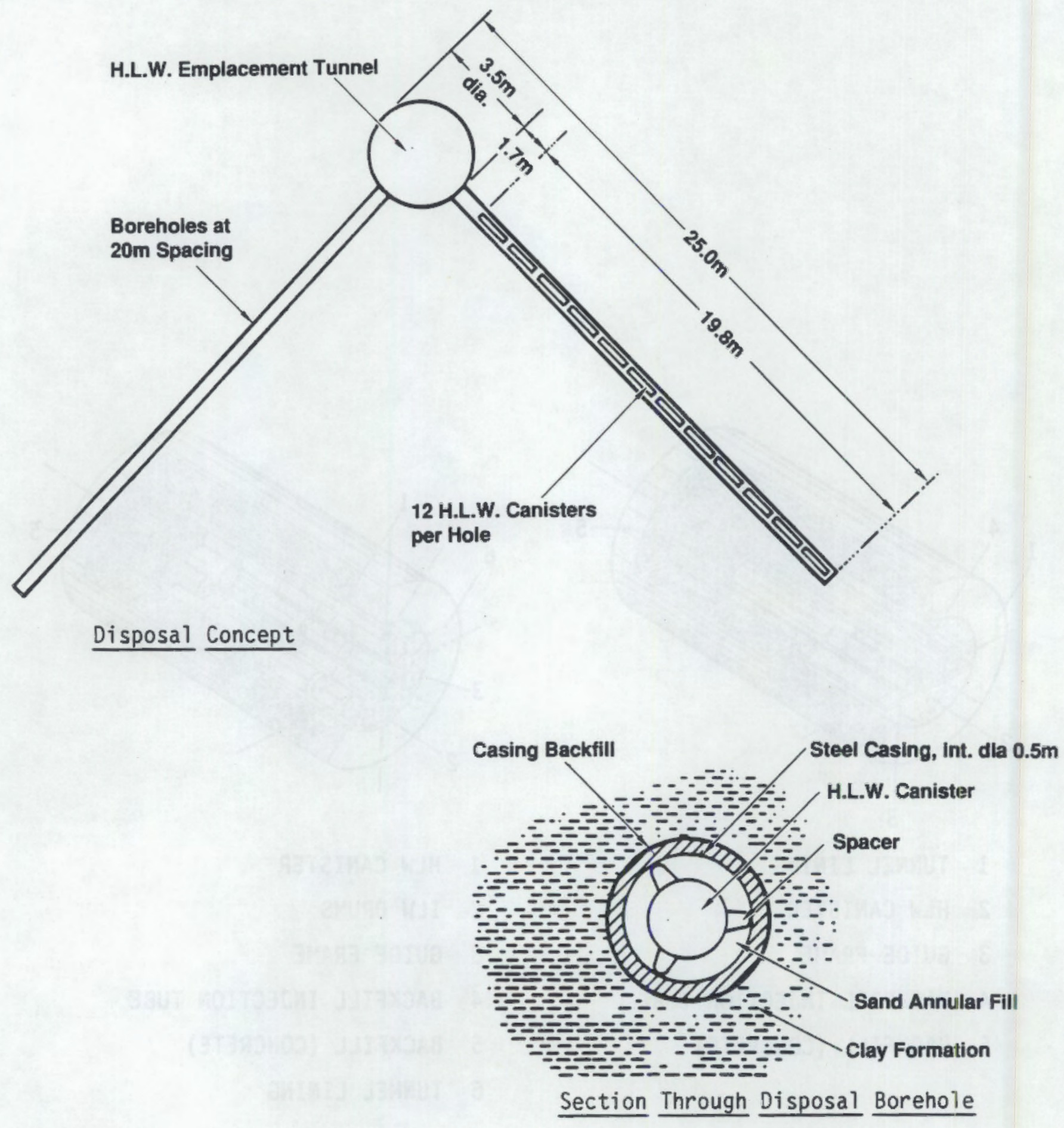

FIGURE 3. Be1gian Concept for Disposal of Canisters of Vitrified HLW in Boreholes from Drifts in Clay 
Top Lid, $4.76 \mathrm{~mm}$ Thickness

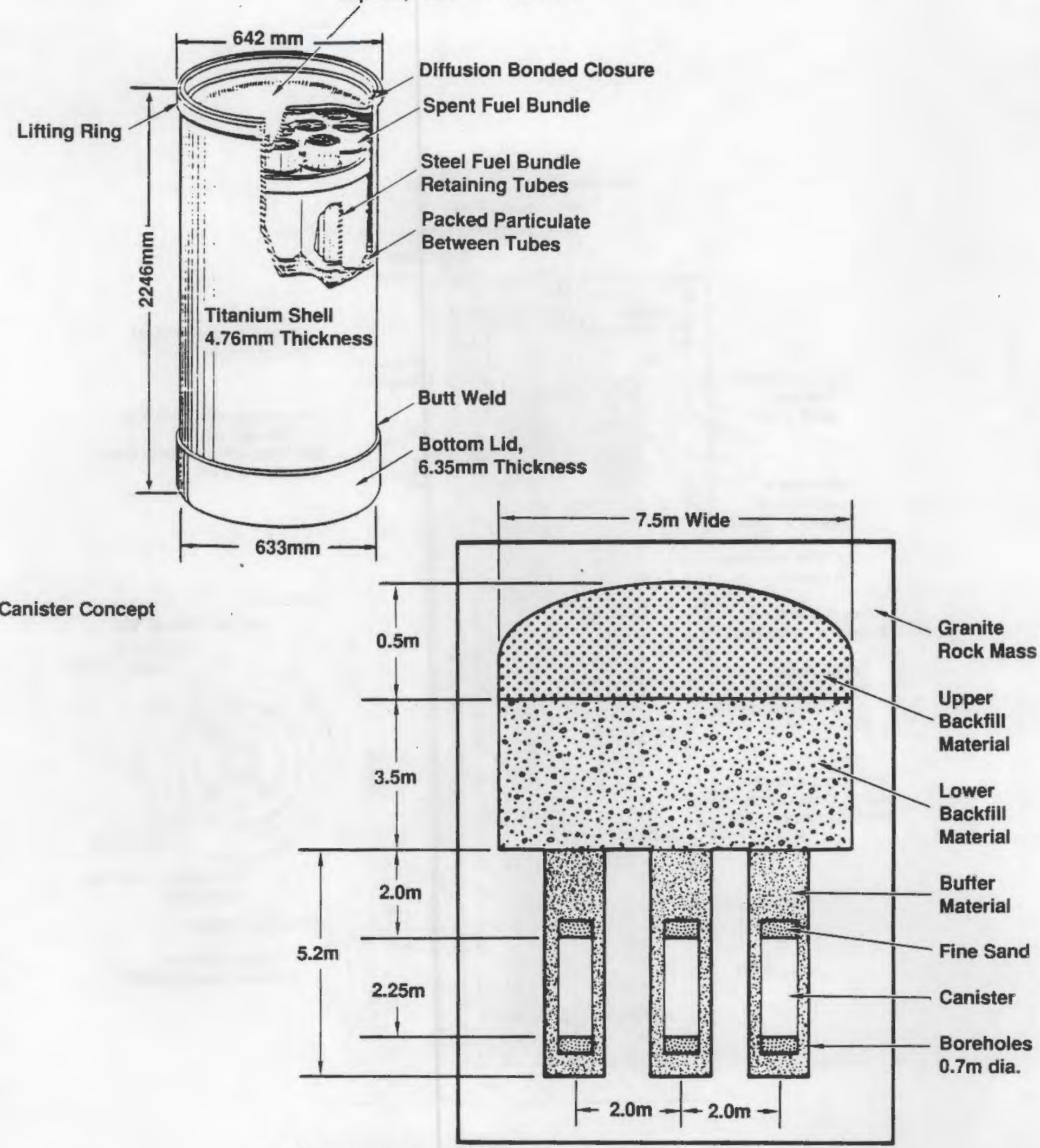

(Transverse Cross Section Through Emplacement Drift About $250 \mathrm{~m}$ Long)

\section{Disposal Concept}

FIGURE 4. Canadian Concept for Canisters and for Disposal of Spent Fuel Assemblies in Granite 


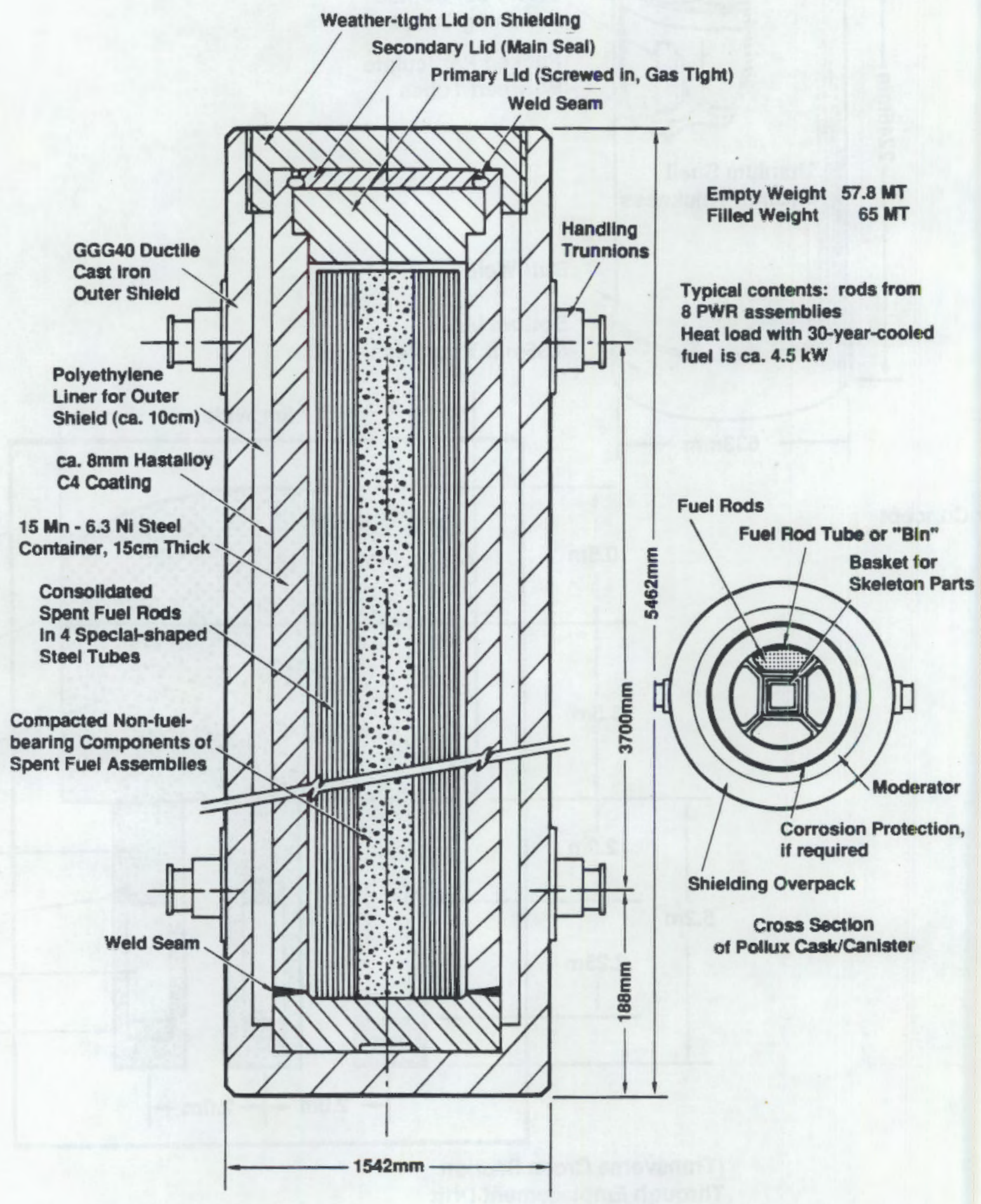

FIGURE 5. German Pollux Cask/Canisters for Consolidated Spent Fuel 


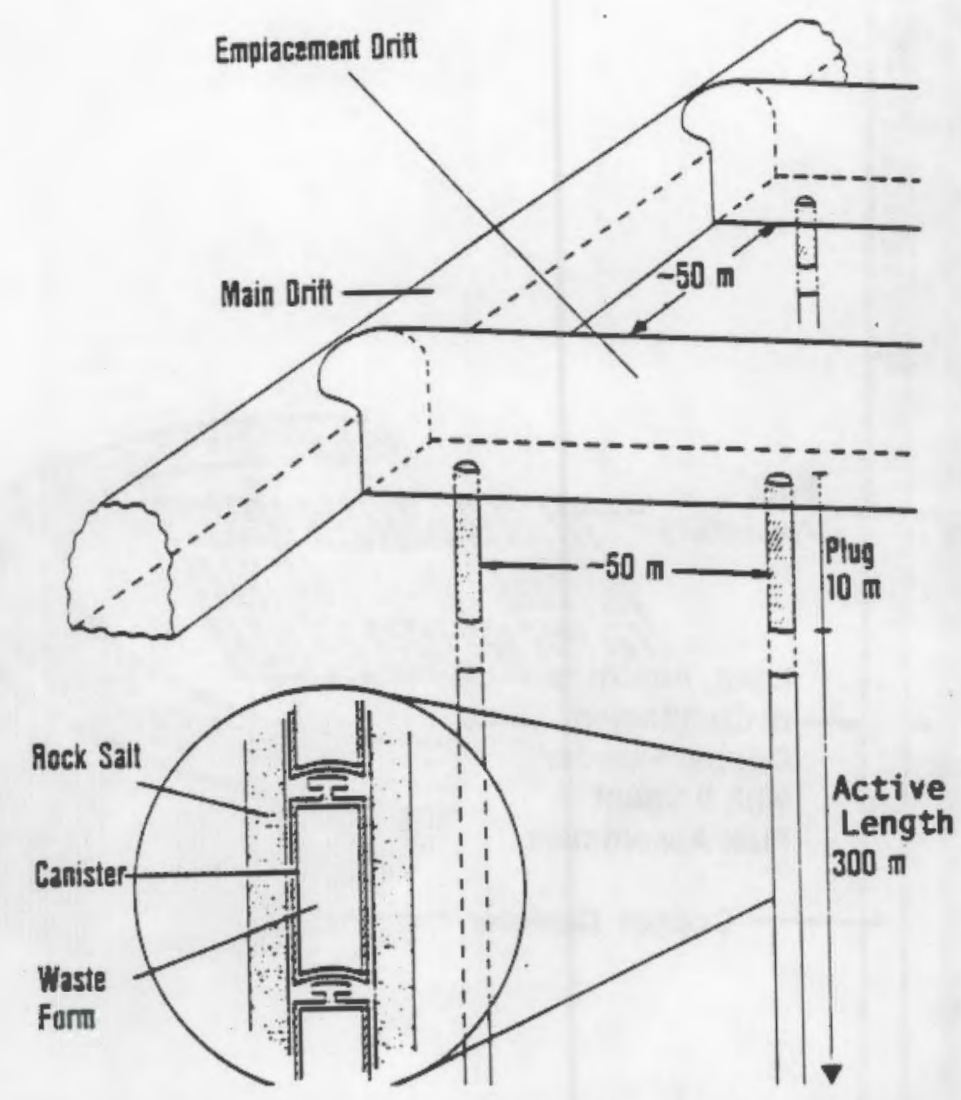

Canisters of Vitrified HLH in Drift Boreholes

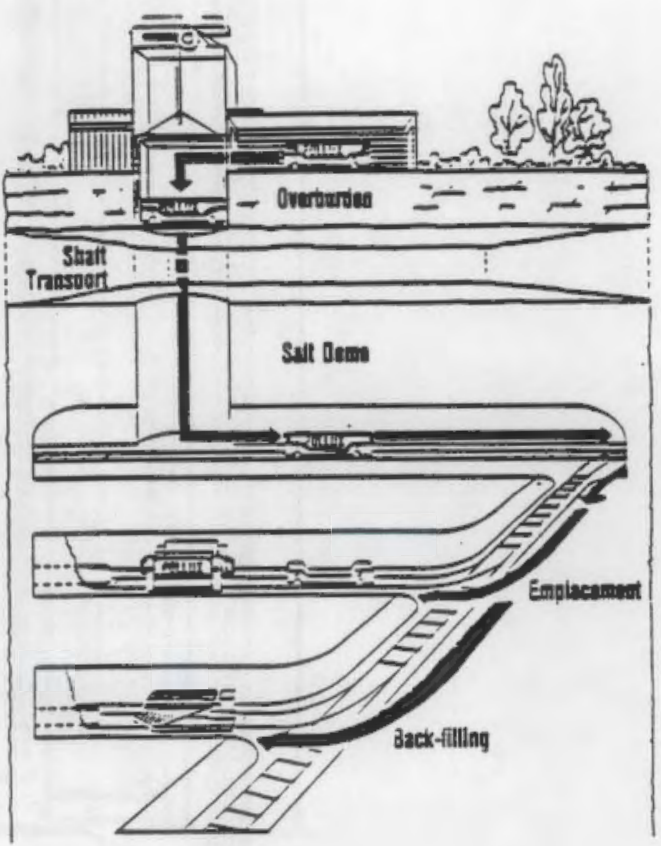

Spent Fuel in Pollux Casks in Drifts

FIGURE 6. German Concepts for Disposal of Vitrified HLW in Boreholes in the Floors of Drifts and Consolidated Spent Fuel in Drifts in Salt 


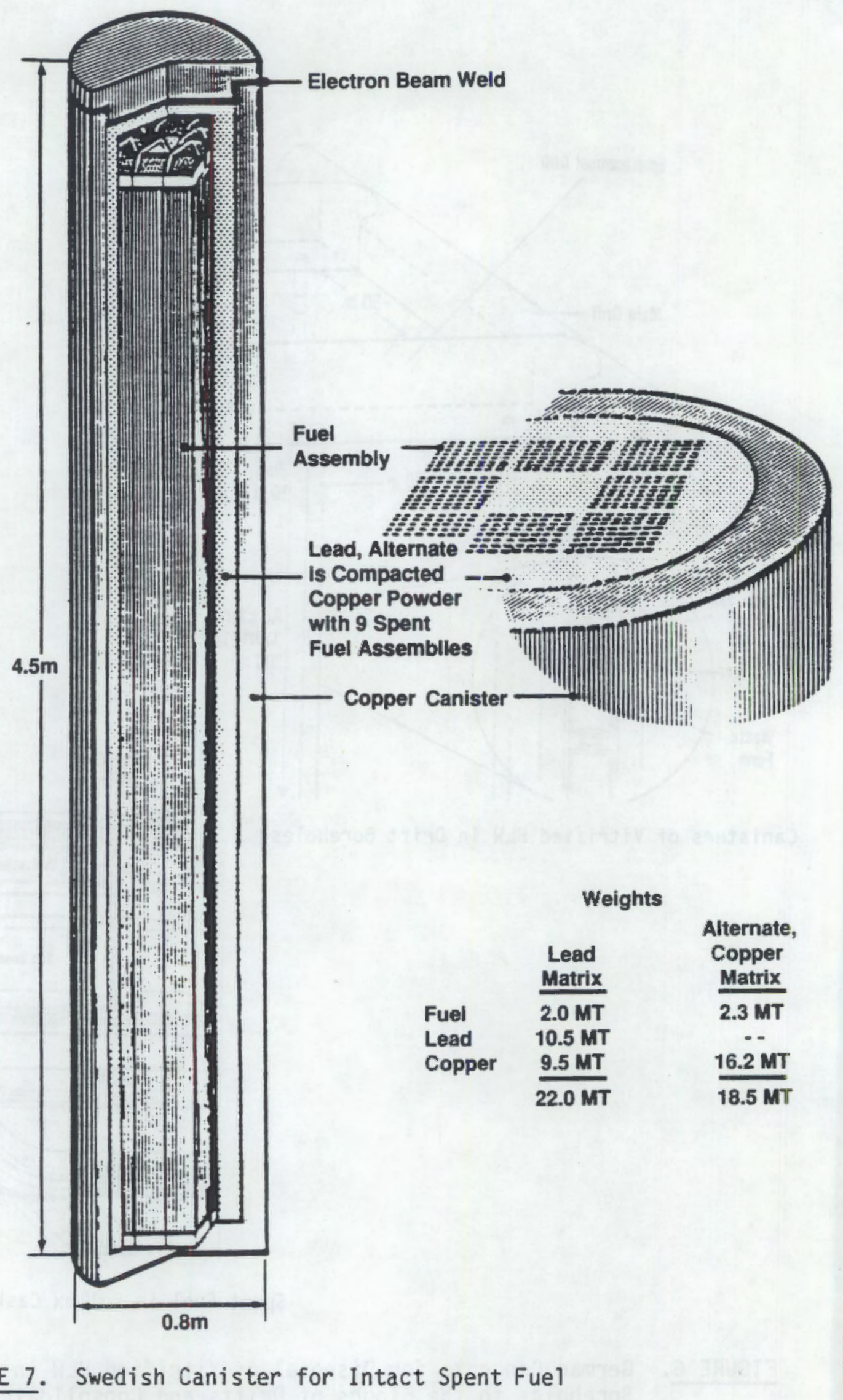




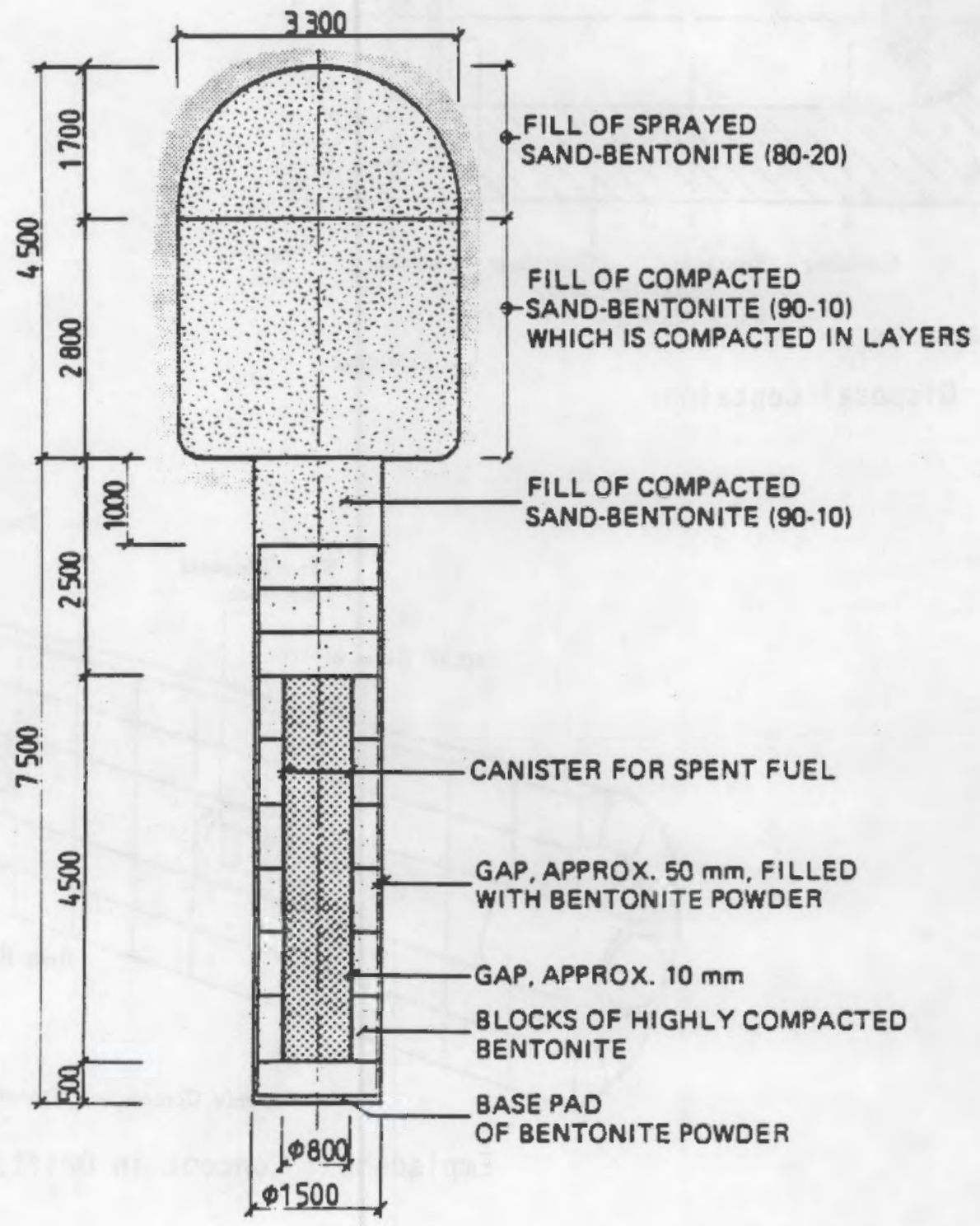

FIGURE 8. Swedish Concept for Disposal of Intact Spent Fuel Assemblies in 8oreholes from Drifts in Granite 

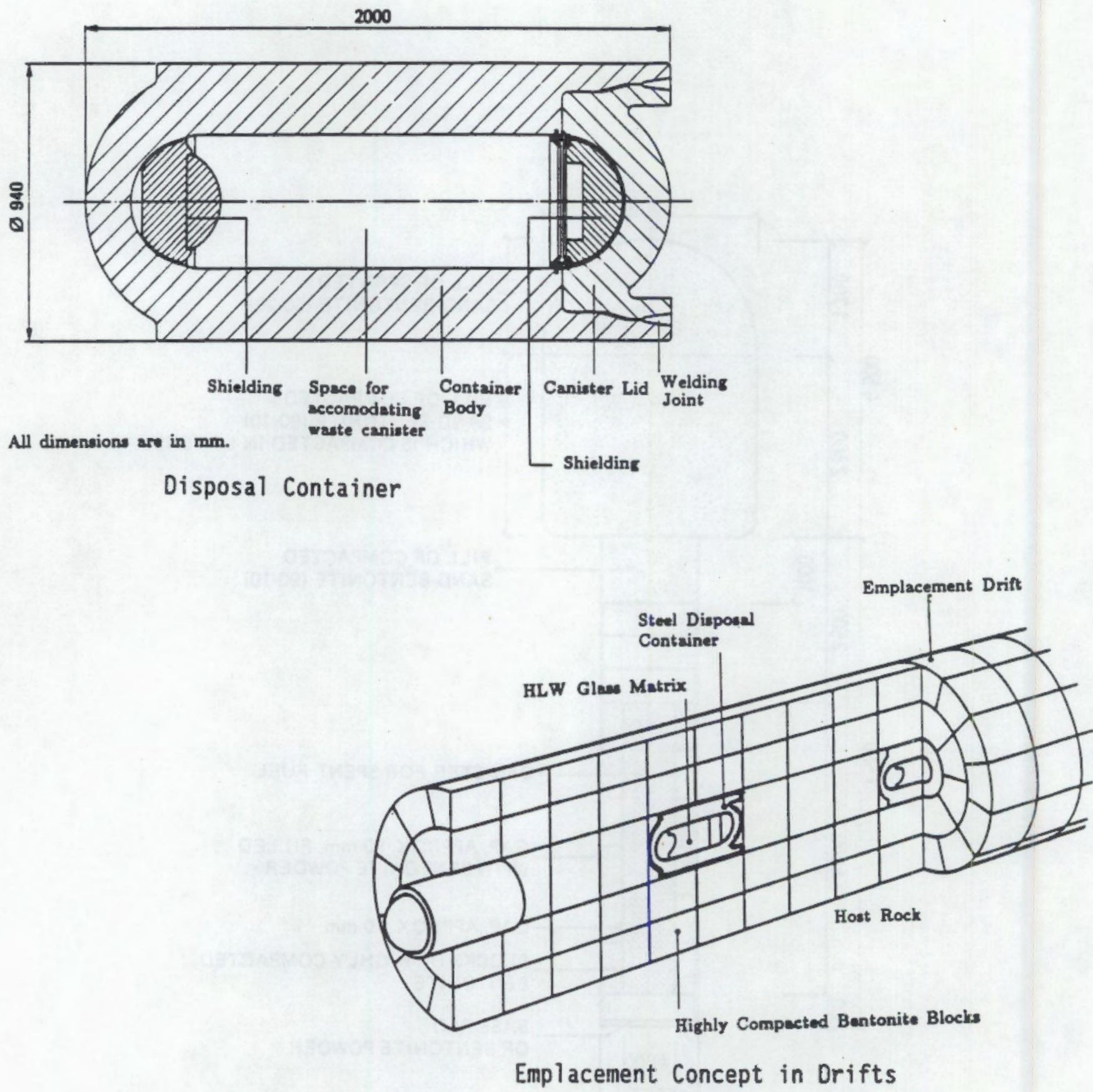

FIGURE 9. Swiss Concept for Disposal Containers and for Disposal of Vitrified HLW in Drifts in Granite 


\title{
CONTENTS
}

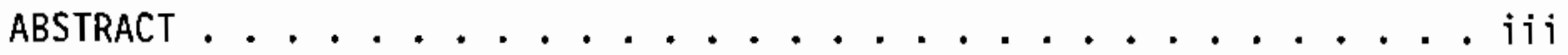

BACKGROUND AND INTRODUCTION ................... v

SUMMARY. ............................. ix

WASTE PACKAGE PlanS IN BELGIUM . . . . . . . . . . . . . . BE.1

WASTE PACKAGE PlanS IN CANADA ................... CA.1

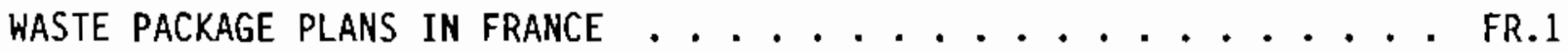

WASTE PACKAGE PLANS IN THE FEdERAL REPUBLIC OF GERMANY . . . . . . . GE.1

WASTE PACKAGE PlanS IN SHEDEN . . . . . . . . . . . . . . . . SW.1

WASTE PACKAGE PLANS IN SWITZERLAND . . . . . . . . . . . . . . . \$Z.1

WASTE PACKAGE PlanS IN THE UNITED KINGDOM ................ UK.1

APPENDIX - GLOSSARY ......................... A.1

REFERENCES .......................... REF 1
\end{abstract}




\section{FIGURES}

1. Canister for HLW Vitrified in France, Germany and the U.K. . . .xvii

2. The Two Belgian Concepts for Disposal of Canisters of Vitrified $\mathrm{HLW}$ in Drifts in Clay ................. . xix

3. Belgian Concept for Disposal of Canisters of Vitrified HLW in Boreholes from Drifts in Clay . . . . . . . . . . . . . . $x x$

4. Canadian Concept for Canisters and for Disposal of Spent CANDU Fuel Assemblies in Granite. . . . . . . . . . . . . . . xxi

5. German Pollux Cask/Canisters for Consolidated Spent Fuel . . . xxi

6. German Concepts for Disposal of Canisters of Vitrified HLW in Boreholes in the Floors of Drifts and Consolidated Spent Fuel in Drifts in Salt ............................... ...

7. Swedish Canister for Intact PWR Spent Fuel . . . . . . . . xxiv

8. Swedish Concept for Disposal of Intact Spent Fuel Assemblies in Boreholes from Drifts in Granite . . . . . . . . . . . . . xxv

9. Swiss Concept for Disposal Containers and for Disposal of Vitrified HLW in Drifts in Granite . . . . . . . . . . . . . xxyi

\section{TABLES}

1. Repository Concepts and Status . . . . . . . . . . . . x

2. Waste Package Status and Components . . . . . . . . . . . xii

3. Waste Form and Canister Characteristics . . . . . . . . . xiv

4. Waste Disposal Container (overpack) and Buffer Characteristics . xvi 
WASTE PACKAGE PLANS IN BELGIUM

\section{Overall Scope/Strategy of Haste Package Concept}

- Plans are to dispose of waste as vitrified HLW, with wastes 50-75 years out-of-reactor (IEAL 1987; Bonne and Manfroy 1986; CEC 1985).

- Overall Status of Repository and Waste Package Concept

- The repository and waste package are conceptual only.

- The repository concept is a single integrated facility for disposal of HLW, TRU wastes, ILW and LLW.

- A test shaft has been sunk in boom clay at Mol where in situ studies are in progress; reconnaissance drilling and studies of geology, hydrology and core sample properties have been carried out there since 1975 (NEI 1988; Schneider et al. 1988).

- Host Rock Material and Mominal Depth

- The reference repository is to be clay (called "boom clay") at approximately $225 \mathrm{~m}$ depth; clay has been selected for study because Belgium has only clay formations that are considered suitable for use as a disposal medium (Schneider et al. 1988).

- Overall Haste Package Components (Schneider et al. 1988)

- Vitrified $H L W$ is to be in a French-type stainless steel canister.

- Bentonite, cement or clay-resin mix are used for buffers and seals.

- Compacted cladding hulls (alpha wastes) will be placed in a lead or lead alloy-lined canister made of stainless steel.

- Regulatory Performance or Barrier Requirements (Waste Form, Canister and/or Container, Packing Around Container)

- Performance requirements are defined only in general terms of radiation protection criteria based on ICRP recommendations and ALARA principles (Van 1seghem 1987).

- No performance requirements are specified at this time; they will be determined later by national authorities from ONDRAF proposals for disposal (IEAL 1987; Clark 1988a).

- Leaching properties of the HLW glass are not expected to play an important role in repository performance; the clay host 
rock is expected to provide the primary retention of radionuclides in the near-field region (Clark 1988a).

- Requirements for Retrievability

- No retrievability requirements are expected by the national authorities (Clark 1988a).

- Regulatory Requirements for Quality Assurance (QA), Nuclear Criticality

- QA requirements are to be determined but QA requirements are an integral part of the Belgian waste management program (Clark 1988a).

- No limitations to control nuclear criticality exist, because the waste form will be borosilicate glass (Clark 1988a).

2. Waste Fonm [e.g.. Borosilicate Glass (Monolithic or Other Form), Intact Spent Fuel Assemblies, Consolidated Spent Fuel Assemblies, etc.]

- Amount and Configuration of Waste Form in a Package

- Monolithic vitrified HLW will be in Cogema-type metal canister (150-1 iters, 43-cm diameter $\times 1.335-\mathrm{m}$ length) (Schneider et al. 1988; Clark 1988a).

- HLW from 1.25 MTU will be in one canister (Sombret 1985).

- A small amount of $H L W$ is vitrified in the Eurochemic PAMELA facility (Schneider et al. 1988)

- Type of Spent Fuel Source

- PWR spent fuel, with burnup, will be up to 33,000 MWD/MT in 1989; will be up to 45,000 MWD/MT later (Clark 1988a).

- Out-of-Reactor Age of the Spent Fuel or Haste

- Vitrified HLW will be cooled for 50-75 years before disposal (Bonne and Manfroy 1986; CEC 1985).

- For HLH:

- Fraction of Filling of Canister

- 150 liters of glass will be in 170-liter canister $(88 \%$ full) (Sombret 1985). 
- Age Before Reprocessing and at Disposal Time

- The age is planned to be 1-5 years before reprocessing (Schneider et al. 1988; Clark 1988a).

- The age is planned to be 50-75 years before disposal (Clark 1988a).

- Matrix Material, if any [Composition, Original form (e.g., Powdered Copper), and Identification of Matrixing Process]

- No matrix is planned (Clark 1988a).

- Support Testing to Qualify the Haste Form

- An active R\&D program has been in progress since 1981 to study HLW glasses and their interactions with clay, including insitu testing in their underground research laboratory in boom clay and surface quarry (Van Iseghem et al. 1987).

- Some support testing is planned to be done as part of the development of the waste acceptance criteria (Clark 1988a).

- The quality of the French HLW form is based on control of vitrification process parameters (Schneider 1988).

3. Waste Canister (see Figure 1)

- Function(s) Provided by the Canister

- The functions are for containment only (i.e., storage, transport, handling) (Clark 1988a).

- Design Requirements [e.g.. Life Expectancy, Temperatures, Pressures (Including Hydrostatic or Lithostatic Pressures), Weights (Including Waste Form), Criticality, Shielding] (Clark 1988a).

- Life expectancy is approximately 50 years (for storage).

- The tenperature 7 imit is $320^{\circ} \mathrm{C}$ maximum.

- The weight of canister is $70 \mathrm{~kg}$; weight of glass in a canister is $360-400 \mathrm{~kg}$ (Sombret 1985).

- There are no requirements for pressure, shielding or criticality.

- Shape and Dimensions

- The cylindrical canister will measure $0.43 \mathrm{~m}$ diameter by $1.335 \mathrm{~m}$ overall height, including filling neck and nozzle. The canister will have a reverse head on the bottom, which 
allows for a stacking height of $1.285 \mathrm{~m}$. The gross canister internal volume will be 170 liters. The net canister internal volume filled will be 150 liters. The total filled weight of a canister will be $480 \mathrm{~kg}$ (Sombret 1985; CEC 1985).

- Wall Thickness and Corrosion Allowance

- The wall thickness will be 5 mm with no corrosion allowance (i.e. the standard French canister) (Sombret 1985).

- Material of Construction

- The material will be Z 15 CN 24-13 stainless steel (French canister) (Sombret 1985)

- Closure Description and Process

- The canister lid will fit into the flanged filling nozzle. Flanges on the lid and filling nozzles will be welded together by automatic plasma arc welding (Alexandre et al. 1987).

- Backfilled Gases, if any

- No backfilled gases are planned (air, Cogema canister) (Clark 1988a).

\section{- Handling Features}

- A handling pintle will be provided on the top of the canister (i.e., the standard French canister) (Clark 1988a).

- Final Testing and/or Support Testing to Qualify the Haste Canister

- Smear testing is the only testing planned, and that is for external contamination after cleaning externally with highpressure water (Alexandre et al. 1987; Clark 1988a).

4. Waste Disposal Container(s), if any

- No disposal containers are identified to date. No container besides the canister is envisaged, but that remains to be determined (Clark 1988a; NEA 1988).

5. Packing (or Buffer) Materials (Clark 1988a)

- Sealing/plugging/backfilling R\&D will be carried out over the next five years.

- Backfill will generally serve as buffer material.

- Host clay rock will act as buffer material. 
- For the concept with holes at 45 degrees from the bottom of the disposal drift, 1-2 cm sand between the canister and the hole is envisioned.

\section{- Design Requirements and Function}

- The primary function of the backfill/buffer is to contribute to structural support for the disposal drifts and heat transfer from the canisters to the walls of the host rock (Clark 1988a).

- Materials of Construction

- Several options are under consideration: bentonite or cement are being considered for buffers/backfill and seals (Schneider et al. 1988; Clark 1988a).

- Shape and Dinensions

- This is not applicable with current concepts (Clark 1988a).

- Testing Requirements

- Testing requirements are not yet defined (Clark 1988a).

\section{- Fabrication Technique}

- Fabrication techniques are not yet defined (Clark 1988a).

\section{Repository Interface (see Figures 2 and 3)}

- Haste Package Handling, Storage, and Emplacement at Repository

- Vitrified HLW is to be stored temporarily in natural air convection cooled concrete caissons in the French storage facility at La Hague for up to five years. A small amount of waste vitrified as borosilicate glass at the Eurochemic PAMELA facility is stored there in an air-cooled vault until a disposal facility is available (Alexandre et al. 1987).

- Vitrified HLW will be transported to a Belgian waste receiving building (to be defined) (Clark 1988a).

- Vitrified HLW will be stored in a storage facility (to be defined) until the repository is ready to accept the waste (Clark 1988a).

- Waste will be moved down into the repository through an access shaft that is near the storage facility (Clark 1988a).

- The repository will have two shafts: one for personnel and waste and the other for ventilation. 
- Each shaft will be about $6 \mathrm{~m}$ in diameter, and lined with monolithic concrete about $1.2 \mathrm{~m}$ thick.

- The emplacement concept is not yet defined. The maximum package weight is expected to be about 11 MT (Clark 1988a).

- For the concept with disposal in the drifts, it is envisaged that ILW will be emplaced radially around the HLW (Clark 1988a).

- Packing Handling and Emplacement

- Essentially no work has been performed on handling and emplacement (Clark 1988a)

- Packing/backfilling will be emplaced around the previously deposited waste canisters by a means to be determined (Clark 1988a).

- Design Limits/Constraints by Repository (e.g., Dimensions, Weights, Temperatures, Areal Heat Loads, etc.) (Clark 1988a; NEA 1988).

- Weight constraints are not yet determined, but maximum lithostatic pressure is 50 atmospheres.

- The maximum temperature of the host rock and host rock/canister interface is $100^{\circ} \mathrm{C}$.

- The maximum heat load is approximately 1.5-2.2 $\mathrm{w} / \mathrm{square} \mathrm{m}$ of horizontal cross section of repository.

- Dimensions and Spacing of Holes in Host Rock

- No holes are planned to be in the emplacement drifts for the concept that involves placing canisters horizontally in the drifts (CEC 1985; Clark 1988a).

- For the concept for emplacement in holes (about $0.45 \mathrm{~m}$ in diameter and about 21 m deep) at 45 degrees down from near the bottom of the drifts, the holes would be about $20 \mathrm{~m}$ apart and each hole would receive about 12 canisters (CEC 1985).

- HLW is to be co-emplaced with ILW (Schneider et al. 1988; Clark 1988a).

- Description of Liner of Holes in Host Rock, if any

- Repository disposal drifts may be lined with concrete blocks $0.60-0.80 \mathrm{~m}$ thickness; the net lined size of the disposal drifts will be about $3.5 \mathrm{~m}$ in diameter (Bonne and Manfroy 1986; CEC 1987; Clark 1988a). 
- Repository disposal drifts may also may be lined with converging steel ribs. Testing is in progress on the convergence-confinement principle for the clay environment (CEC 1987)

- No liner is planned for the concept with diagonal holes from the bottoms of the disposal drifts. Plans are to add about 1$2 \mathrm{~cm}$ of sand between the canister and the wall of the hole (CEC 1985; Clark 1988a).

- Sealing Materials for the Emplacement Holes and How Emplaced

- Sealing materials in galleries may be bentonite, cement, or clay-resin mix, but remain to be determined (Schneider 1988; Clark 1988a).

- Retrievability Provisions, if any

- No specific provisions are planned (Clark 1988a).

- Monitoring Provisions in Emplacement Holes, if any

- No monitoring provisions are planned (Clark 1988a). 


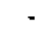


WASTE PACKAGE PLANS IN CANADA

\section{Overall Scope/Strategy of Haste Package Concept}

- Overall Status of Repository and Waste Package Concept

- Efforts are focused on assessing the concept of disposal at a depth of 500 to $1000 \mathrm{~m}$ in plutonic rock (i.e., granite). The concept assessment will be submitted in 1988/1989 for regulatory review (Hancox et al. 1987).

- After the concept is accepted by provincial and federat governments, (expected in early 1990s), site selection, design, and construction of demonstration facilities witl be considered.

- Most of the container design and development has been directed at the disposal of spent fuel; however, some container testing and research data are also relevant to the containment of inmobilized reprocessing waste (Johnson et al. 1987).

\section{- Host Rock Material and Mominal Depth}

- Plutonic rock is the reference host rock, particularly granite or gabbro rock at 500-1000 $\mathrm{m}$, and probably in the Canadian Shield area (Johnson et al. 1987; Frost 1988; NEA 1988).

- The criteria defining an appropriate geologic formation include: a) many potential sites in the geographical region of interest, b) long-term geologic stability, c) absence of economic amounts of minerals, d) groundwater transport times of hundreds of thousands of years from the rock mass to the surface, and e) geological and hydrological characteristics that can be readily determined (Hancox et al. 1987).

\section{- Overall Waste Package Components}

- The components are spent fuel, metal canister, possible inner structural canister; possible matrix material, buffer material (Johnson et al. 1987).

- Regulatory Performance or Barrier Requirenents (Waste Form, Canister and/or Container, Packing Around Container)

- No regulatory requirements that are specific to spent fuel/HLW disposal have been issued (IEAL 1987).

- Proposed regulatory guides are being used for the concept assessment phase, and will be finalized after completing the concept assessment phase; other regulatory requirements may also be developed at that time. 
- The guidelines state that the predicted radiological risk to individuals from a disposal facility shall not exceed $1 E-6$ fatal cancers and serious genetic effects in one year. The time period for performance is 10,000 years.

- The guidelines require multiple barriers, but impose no specific requirements.

- A waste package design lifetime of at least 500 years is being used as a guide for the concept assessment phase; 500 years was selected to provide essentially complete containment during the high-activity period (Bechthold et al. 1987).

- A waste package must withstand $150^{\circ} \mathrm{C}$, a basis developed in the concept assessment study (Bechthold et al. 1987).

- A waste package must withstand pressures of $10 \mathrm{MPa}(100$ atmospheres), a bas is developed in the concept assessment study (Bechthold et al. 1987).

- Requirements for Retrievability

- No regulatory requirements currently exist on retrievability, but Atomic Energy of Canada Limited (AECL) policy is that retrievability should be maintained during repository operation. $A E C L$ policy does not require retrievability following repository closure (IEAL 1987).

- Regulatory Requirements for Quality Assurance (QA), Nuclear Criticality

- The Canadians are committed to total quality assurance for activities relating to the siting, design and construction of a nuclear fuel waste disposal vault. Quality assurance procedures for several key areas have been formalized and the process is continuing (NEA 1988).

- General requirements for QA are given in the guidance for the concept assessment phase only; final requirements are to be determined (IEAL 1987).

\section{Waste Form}

- The reference waste form is intact CANDU spent fuel assemblies. Conditioning and consolidation techniques are believed to create complications (Nuttal 1987; Johnson et al. 1987).

- In the event that fuel reprocessing would be used, some work on HLW forms has been done, with borosilicate glass as the primary form and aluminosilicate 91 ass and titanosilicate 
glass-ceramics as alternative HLW forms. Other alternative HLW forms are sphene-based glass ceramics (Johnson et al. 1987).

- Anount and Configuration of Waste Form in a Package (Baumgartner and Simmons 1987)

- The reference package contains 72 fuel bundles (about 1.4 MTU with about $300 \mathrm{~W}$ heat).

- Type of Spent Fuel Source and Overview Description of Spent Fuel (or Reference to Description Information)

- The spent fuel is CANDU fuel bundles (50 cm long, $10 \mathrm{~cm}$ diameter). The original fuel is natural uranium dioxide pellets in Zircalloy-4 tubes, with 19 to 37 tubes/assembly and $19 \mathrm{~kg} \mathrm{U} /$ assembly. The average burnup is 7,500 MWD/MTU, resulting in about $0.22 \% \mathrm{U}-235,0.38 \%$ plutonium, and $0.76 \%$ fission products. The reference heat content at 10 years is about 218 W/MTU (Baumgartner and Simmons 1987; Nutta) 1987; Frost 1988).

- Out-of-Reactor Age of the Spent Fuel or Waste (Schneider et al. 1988; Baumgartner and Simmons 1987)

- The reference spent fuel is nominally 10 years out-of-reactor at the time of canisterization.

- The spent fuel age will be least 10 years, and typically 50 to 75 years at time of disposal.

- Spent fuel is stored in pools at reactor sites. The fuel is stored horizontally, in stacked racks. Except for sma11 amounts of fuel currently stored dry in concrete casks, inpool storage capacity is generally adequate until about the mid-1990s.

- Extended storage is likely to be dry. Four storage concepts are under study: convection vaults, concrete casks, concrete integrated casks (for storage, transportation, and disposal), and metal casks.

- For HLW:

- The reference form is intact spent fuel, but the alternative "reference" HLW form is borosilicate glass (Johnson et al. 1987). 
- Matrix Material, if any (Composition, Original Form, and Identification of Matrixing Process)

- In the thin wall container concept, (the reference concept), the empty spaces inside the container would be filled with a granular material (such as glass beads or graded silica sand), compacted by vibrational means to form a matrix that would provide support for the external pressures following disposal. Filling of the empty spaces with an alloy with low melting point (such as lead) is one of several aiternative concepts (Johnson et al. 1987; Bechthold et al. 1987; Hancox 1988).

- In the iron-based concept, the fuel bundles would be inserted into carbon-steel structural tubes, and the appropriate number of tubes would be loaded into a single outer structural canister of carbon steel. As an alternative, the space between the tubes could be filled with a granular material or with molten lead as with the other concept. In addition, the outer canister could be sealed in a corrosion-resistant container such as titanium (Johnson et al. 1987).

\section{- Support Testing to Qualify the Waste Form}

- A significant spent fuel R\&D program has been underway for several years to determine the mechanisms of spent fuel dissolution under anticipated repository conditions (Hancox 1987).

\section{Waste Canister (see Figure 4)}

- Function(s) Provided by the Canister

- The canister provides for confinement of contents during interim storage and transportation and in-repository corrosion resistance for 500 to 1,000 years (Bechthold et al. 1987; Johnson et al. 1987).

- Design Requirements [e.g., Life Expectancy, Temperatures, Pressures (Including Hydrostatic or Lithostatic Pressures), Heights (Including Waste Form), Criticality, Shielding).

- The canister's life expectancy is 500 years as established by the concept study. The canister temperature limit is in the range of $100-150^{\circ} \mathrm{C}\left(100^{\circ} \mathrm{C}\right.$ may be the limit due to tendency for crevice corrosion in titanium) (Johnson et al. 1987; Bechthold et al. 1987).

- The zone of rock overlying the vault that undergoes extension due to the thermal expansion of the rock mass, must be no greater than $100 \mathrm{~m}$ from the surface (Baumgartner et al. 1987). 
- The sustained long-term far-field temperature must be no higher than $75^{\circ} \mathrm{C}$ (Baumgartner et al. 1987).

- The canister must withstand $150^{\circ} \mathrm{C}$ and the hydrostatic pressure at $1,000 \mathrm{~m}$ depth or about 100 atmospheres (Bechthold et al. 1987).

\section{- Shape and Dimensions}

- The 72 spent fuel assemblies in the reference canister are each placed in a thin steel basket and then in a thin titanium shell. The fuel assemblies are stacked four high, with 18 assemblies in each row. The canister dimensions would be about $0.63 \mathrm{~m}$ in diameter and about $2.25 \mathrm{~m}$ long. The empty spaces in the titanium canister will be supported structurally by filling with granular material that is vibrationally compacted. The lid is recessed into the cylindrical canister (Johnson et al. 1987).

- An alternative canister is an iron-based, stressed-steel cylindrical container with a titanium-shell overpack, and a low-carbon steel basket. Dimensions would be about the same as the thin walled canister described above. Because of poor cost-effectiveness, this concept has been replaced as the reference concept with the prior, thin-walled titanium concept discussed above (Johnson et al. 1987).

- Another alternative canister/disposal container under development is the steel-lined integrated concrete cask (for storage, transportation and disposal.) Its outer size is $2.6 \mathrm{~m}$ diameter and $3.6 \mathrm{~m}$ high, with $1.64 \mathrm{~m}$ in inside diameter. It would contain nearly 400 fuel bundles stacked horizontally on racks. The gross weight would be 70 MT (Frost 1988).

\section{- Hall Thickness and Corrosion Allowance}

- The reference canister is titanium, $4.76 \mathrm{~mm}$ thick on the sides and top, and $6.35 \mathrm{~mm}$ thick on the bottom head for support during handling. The corrosion allowance is not stated (Johnson et al. 1987).

- The iron stressed-shell canister would be $45 \mathrm{~mm}$ thick, with the top and bottom plates at $76 \mathrm{~mm}$ thick. The titanium overpack would have the same thickness as the reference titanium canister (Bechthold et al. 1987).

- The concrete integrated cask walls would be $0.98 \mathrm{~m}$ thick in total. The corrosion allowance is not stated (Frost 1988). 
- Material of Construction (Frost 1988; Johnson et al. 1987; Bechthold et al. 1987)

- Internal baskets or racks would be mild steel.

- The reference concept uses thin titanium grades 2 or 12 in the shell.

- The alternative iron-based concept uses thick stressed mild steel container with titanium grades 2 or 12 as an overpack.

- Other materials being considered are copper, Hastelloy C-276, Inconel 625, and ceramics and ceramic-coated metals.

- The Concrete Integrated Container (CIC) alternative would use steel-lined reinforced high-density concrete with an outer shell of mild steel.

- Closure Description and Process

- The top lid of the reference titanium canister (approximately the same diameter as the canister) would be tapered and will be pressed into place in the tapered top of the canister and resistance-heated diffusion-bonded to the shell. The bottom plate would have a thickness of 6.35 mun to support the weight during lifting (Hancox et al. 1987; Bechthold et al. 1987).

- The titanium top lid of the alternate iron-based concept with titanium cladding will be essentially the same as for the reference titanium canister, and the closure process will be about the same (Bechthold et al. 1987).

- The concrete integrated cask would have a concrete filled steel-lined lid that is bolted to the cask. Metallic and elastomeric seals would be used (Frost 1988).

- Backfilled Gases, if any

- No backfilled gases are discussed in documents.

- Handling Features

- The metal canisters will have either a welded ring around the circumference of the canister near its top or three holes in the top rim or a single lifting lug with one hole. The bottom of the canister will be thicker to provide support for handling. The total weight of a filled canister is estimated to be 2,810 kg (Hancox et al. 1987; Bechthold et al. 1987).

- The concrete integrated cask will have two upper and two lower trunnions (Frost 1988). 
- Final Testing and/or Support Testing to Qualify the Waste Canister

- The final canister would likely have the seal tested ultrasonically for flaws and would use a helium leak test. (Baumgartner et al. 1987)

4. Haste Disposal Container(s), if any

- The reference canister of thin-walled titanium would not have an additional disposal container (Bechthold et al. 1987)

- The alternative container of stressed mild steel would have a titanium overpack as the disposal container (Bechthold et al. 1987)

- The concrete integrated cask container serves as the canister and the disposal container (Frost 1988)

- See Section 3, above, for additional information.

5. Packing (or Buffer) Materials

- Design Requirements and Function

- The primary functions of the buffer would be to seal the waste containers in the repository, to retard radionuclide release from the containers to the host rock, and to provide good transfer of heat to the host rock (Johnson et al. 1987).

- The buffer material should have high compacted dry density, good thermal conductivity, and strength without impairing swelling potential (Bechthold et al. 1987).

- The temperature of the buffer material should not exceed $100^{\circ} \mathrm{C}$ to maintain the performance of the buffer material and to assure low crevice corrosion of the titanium of the waste canister (Johnson et al. 1987).

- A pressure bulkhead will be constructed after each room is filled to withstand the buffer and backfill swelling and hydraulic pressures (Baumgartner and Simmons 1987).

- Materials of Construction

- The reference material would be a 1:1 dry mass ratio of Avonseal sodium bentonite and quartz sand (Avonseal contains $80 \%$ sodium-based montmorillonite, $10 \%$ illite, and smaller amounts of quartz, feldspar, gypsum and carbonates). Moisture content of the bentonite would be about $18 \%$. The final dry specific gravity would be about 1.65 (Graham et al. 1986; Johnson et al. 1987). 
- The reference backfill material for the disposal drifts would be a mixture of $70-80 \%$ sand and crushed repository rock, and 20-30\% lake clay. The final dry specific gravity should be about 2.05 (Johnson et al. 1987).

\section{- Shape and Dimensions}

- For disposal hole emplacement (the preferred concept), the bottom of disposal hole in floor of repository room would have a 1-m depth of packing material; containers would be surrounded with $0.25-m$-thick of compacted packing material; this is the preferred concept because it requires less buffer material than the in-room concept, and analyses have shown the release rate of radionuclides to the geosphere is equal to or less than that from containers emplaced in the in-room concept (Johnson et al. 1987).

- For in-room emplacement, containers would be placed vertically on a 1-m-thick bed of buffer material. The canisters would be covered with crushed buffer/packing material for 1-2 m above the containers. The top of room would be backfilled with the backfill material (Johnson et al. 1987; Schneider et al. 1988).

\section{- Testing Requirements}

- No testing requirements are discussed in documents.

\section{- Fabrication Technique}

- Buffer (or packing) material is to be pre-mixed, emplaced loosely, and compacted in place (see Section 6, below).

- Methods of emplacing the backfill material are still under study, especially for emplacing the top 2 m of material (Johnson et al. 1987).

\section{Repository Interface (see Figure 4)}

- Waste Package Handling. Storage, and Emplacenent at Repository

- The reference concept includes spent fuel bundles loaded into canisters/containers in a facility at the repository site. The design basis throughput rate is 8100 canisters/yr or 583,200 fuel bundles/year for about 40 years. The total spent fuel in the reference repository is 191,000 MTU (Baumgartner and Simons 1987; Hancox 1987; NEA 1988).

- Spent fuel will be received by truck or rail at the disposal facility in shipping modules (two modules at a time) that contain 96 fuel bundles each. The two modules will be transported in an air atmosphere in a single, rectangular 
truck cask [type $b(U)$ ] constructed of monolithic stainless steel. A similar reference rail cask has also been conceptualized that will accept six spent fuel modules. A potential barge/tug concept would accept multiple truck or rail casks (Nash 1986; Kempe et al. 1987).

- The spent fuel will be unloaded wet and stored for an interim period in a water pool (Baumgartner and Simmons 1987; Hancox et al. 1987).

- When ready for packaging, the spent fuel modules will be taken to a hot cell. In the hot cell, the used fuel bundles will be removed one at a time and placed four-deep into 18 of 19 pipes arranged as a single basket. The loaded basket assembly will be placed into a canister. For the reference particulatepacked concept, the void space will be filled with particulates and vibrational compacted. The top head of the canister will be pressed in place and sealed with a diffusion bond (Baumgartner et al. 1987).

- For the iron-based, titanium-overpacked canister alternative, the empty iron canister will be overpacked and the overpack lid connected to the steel lid before they are placed in the hot cell. Loading and sealing would be the same as for the reference titanium canister (Bechthold et al. 1987).

- After ultrasonic bond inspection and helium leak testing, the containers will be transferred to a lag storage area. The spent fuel container will be loaded into a shielded transfer cask and transferred underground in a dedicated waste handling shaft. The cask will be moved either to an underground storage area or directly to an emplacement room in dedicated haulage-ways (Baumgartner and Simmons 1987).

- Two basic emplacement techniques with many variations have been considered: room emplacement and borehole emplacement in a single level (preferred for spent fuel because of lower cost) or in a multiple level (may be acceptable for a small but deep rock formation or for HLW) (Bechthold et al. 1987; Baumgartner and Simmons 1987).

- In the preferred borehole emplacement (concept) an array of $1.2 \mathrm{~m}$-diameter by about 5.2-m deep boreholes would be drilled in the floors in excavated rooms or drifts. When all emplacement boreholes within a room are filled and lined with buffer material, the room will be backfilled and sealed.

- In the room emplacement concept two containers at a time will be transported to the emplacement room in a manned diesel powered transporter. Four containers will be 
placed upright on the floor of the room before backfilling with packing material to a height of $1 \mathrm{~m}$ above the containers.

\section{- Packing Handling and Emplacerent}

- The buffer material in the bottom of the emplacement holes will be emplaced loosely and compacted in place. A $0.7-\mathrm{m}-$ diameter hole (4.2 m deep) will be bored through the buffer material. The canister will then be emplaced in the hole. The annular gap of about $50 \mathrm{~mm}$ around the container will be filled with loose sand to improve heat conduction. The remaining buffer material (above the canister) will be emplaced loosely. The top of each hole will then be filled with loose buffer material and compacted in place. This concept was selected because an engineering study showed that it would facilitate separation of active and inactive operations during waste emplacement (Baumgartner and Simnons 1987; NEA 1988).

- The disposal drifts will be backfilled by one or more methods to be determined. Currently the lower part of a drift would likely be compacted in place and the upper part would likely be backfilled pneumatically (Hancox et al. 1987; Johnson et al. 1987).

- Design Limits/Constraints by Repository (e.g., Dimensions, Heights, Temperatures, Areal Heat Loads, etc.)

- The disposal container skin temperature will be limited to $100^{\circ} \mathrm{C}$ to maintain performance (i.e., to assure control of swelling and sealing around the canisters) of the buffer material, to assure that crevice corrosion of titanium container material is acceptably low, and to assure stability of the disposal formation due to stresses (Johnson et al. 1987).

- The zone of rock overlying the vault that undergoes extension due to the thermal expansion of the rock mass must be no greater than $100 \mathrm{~m}$ from the surface (Baumgartner and Simmons 1987).

- The sustained long-term far-field temperature must be no higher than $75^{\circ} \mathrm{C}$. This criterion controls the gross allowable thermal load in the repository (Baumgartner and Simnons 1987).

- The design pressures will be in the order of $10 \mathrm{MPa}$ (1460 ps $i$ ), from hydrostatic head (Johnson et al. 1987). 
- Dimensions and Spacing of Holes in Host Rock

- Holes for borehole emplacement will be $1.2 \mathrm{~m}$ in diameter and about $5.2 \mathrm{~m}$ deep. The minimum center-center spacing will be about $2 \mathrm{~m}$ in a square array with three holes in the width of the emplacement drift. Hole spacing will be based on limiting the maximum host rock temperature and resultant stresses, and is being studied (Johnson et a1. 1987; Baumgartner and Simmons 1987; NEA 1988).

- A rectangular array of 60 parallel disposal drifts will be constructed in a total plan area of $2 \mathrm{~km}$ by $2 \mathrm{~km}$. Each disposal drift will be about $250 \mathrm{~m}$ long (including about $50 \mathrm{~m}$ of access drift length) by $7.5 \mathrm{~m}$ wide by $5 \mathrm{~m} \mathrm{high}$ to the top of the arched ceilings. Each emplacement drift would accept about 240 canisters (Baumgartner and Simmons 1987; Nuttal1 1987).

- Description of Liner of Holes in Host Rock, if any

- No hole liner is planned (Johnson et al. 1987).

- Sealing Materials for the Emplacement Holes and How Emplaced

- The buffer material will be as described above (Johnson et al. 1987).

- Tunnel backfill material will be as described above (Johnson et a1. 1987).

- Retrievability Provisions, if any

- Retrieval is required during repository operation, but not after closure. Any retrieval provisions after closure must not compromise the performance of the repository (IEAL 1987).

- Monitoring Provisions in Emplacement Holes, if any

- No specific requirements for monitoring the repository performance during operation or after closure have been developed (IEAL 1987). 

WASTE PACKAGE PLANS IN FRANCE

\section{Overall Scope/Strategy of Haste Package Concept}

- Overall Status of Repository and Waste Package Concept (NEA 1988)

- France will reprocess all spent fuel, and will dispose of only HLW that has been vitrified; HLW have been vitrified for a number of years and are stored in air. Their waste package concept has not been developed in detail, but the package will include the current and future canisterized and vitrified $H L W$.

- France will dispose of vitrified HLW in one or more deep geological formations. Repository design will begin in the early 1990s with startup about 2010 (Isaacs 1988).

- The repository concept has not yet been developed. An underground site validation laboratory site will be selected in 1991, and if successful, will become the final repository following construction in 2004-2010 (Isaacs 1988).

- An underground research laboratory in granite has been used for generic studies for several years.

- Engineered and geologic barriers are under active investigations.

- Host Rock Material and Mominal Depth (NEA 1988).

- Based on a survey of possible repository sites completed in 1987, four potential host rocks have been selected for characterization: one each in clay, outcropping granite, schists, and salt.

- The minimum depth of the disposal horizon is to be 150 to $200 \mathrm{~m}$, and the maximum depth is about $1000 \mathrm{~m}$ (IEAL 1987; Goguel 1987).

- Overall Haste Package Components (Sombret 1985)

- The components will be vitrified HLW, waste canister, a possible disposal container (overpacks of metals and ceramics are considered), and buffer material.

- Regulatory Performance or Barrier Requirements (Haste Form, Canister and/or Container, Packing Around Container) (Sombret 1985;

IEAL 1987; Goguel 1987)

- No radiation protection limits have been set for the boundary of a HLW repository. 
- Safety of a repository must be demonstrated by modeling for at least 10,000 years.

- No performance rules exist yet for a repository, but each barrier should contribute to the safety of the repository

- A package is desired that will last 1,000 years.

- The geologic setting should have short-term and long-term stability, including stability from effects of the man-made changes.

- Existing or potential future resources should be absent to minimize the potential for human intrusion.

- The repository site should be capable of being modeled.

- Requirements for Retrievability

- Retrievable requirements are not yet determined in France (IEAL 1987).

- Regulatory Requirenents for Quality Assurance (QA), Nuclear Criticality

- No information was found on criticality requirements.

2. Waste Form [e.g.., Borosilicate Glass (Monolithic or Other Form), Intact Spent Fuel Assenblies, Consolidated Spent Fuel Assemblies, etc.]

- The waste form is monolithic borosilicate glass with about 13 weight percent of waste oxides for PWR wastes (Sombret et al. 1985).

- Amount and Configuration of Haste Form in a Package (Sombret 1985).

- About $400 \mathrm{~kg}$ of monolithic vitrified HLW in 150 liters is in a cylindrical canister.

- Vitrified high-level waste from 1.25 MTU is in one canister.

- The fraction of filling of canister is $88 \%$ (150 liters of glass in a 170-liter canister).

- Type of Spent Fuel Source and Overview Description of Spent Fuel (or Reference to Description Information)

- Most spent fuel will be from PWRs at a typical exposure of about 33,000 MWD/MT. Some spent fuel will be from four GCRs (reprocessed and vitrified at Marcoule), from materials test reactors, and from FBRs (in the future) (Lung et al. 1987). 
- Out-of-Reactor Age of the Spent Fuel or Waste (Sombret 1985).

- The out-of-reactor age of spent fuel is about 1 to 5 years before reprocessing and vitrification is 1 to 5 years and is approximately 30 years before disposal.

- Interim storage after vitrification will be in air-cooled vaults at the vitrification facility. In addition, it is planned to be stored 20 to 30 years at the disposal site (Isaacs 1988).

- Matrix Material, if any [Composition, Original Form (e.g., Powdered Copper), and Identification of Matrixing Process]

- No matrix material is to be used (Sombret 1985).

- Support Testing to Qualify the Haste Form

- Vitrified HLW quality is based on control of vitrification process parameters (Sombret 1985).

3. Haste Canister (see Figure 1)

- Function(s) Provided by the Canister

- The canister provides for handling and containment during storage. The functions during disposal are not yet defined (Sombret 1985).

- Design Requirements [e.g., Life Expectancy, Temperatures, Pressures (Including Hydrostatic or Lithostatic Pressures), Heights (Including Waste Form), Criticality, Shielding]

- No information was found on life expectancy of the canister.

- The empty canister weighs $70 \mathrm{~kg}$, and the glass weighs 360 $400 \mathrm{~kg}$ (Sombret 1985).

- Shape and Dimensions

- The canister is cylindrical and measures $0.43 \mathrm{~m}$ diameter by $1.335 \mathrm{~m}$ overall height, including filling neck and nozzle. The canister has a reverse head on the bottom, which allows for a stacking height of $1.285 \mathrm{~m}$. The gross canister internal volume is 170 liters, and the net canister internal volume filled is 150 liters. The total filled weight of the canister is $480 \mathrm{~kg}$ (Sombret 1985; CEC 1985).

- The cylindrical canister for the wastes vitrified at Marcoule is $0.50 \mathrm{~m}$ in diameter and $1.0 \mathrm{~m}$ high (Lung et a T. 1987). 
- Wall Thickness and Corrosion Allowance

- The canister thickness is 5 man (Sombret 1985; Clark 1988b).

- There is no corrosion allowance (Clark 1988b).

- Material of Construction

- The canister material is special stainless steel designated as Z 15 CN 24-13 (Sombret 1985).

- Closure Description and Process

- The canister lid is inverse, hat-shaped. The lid (except its flange) fits into the filling nozzle of the canister. The flanges of the lid and filling nozzle are welded together (Sombret 1985).

- The weld closure is done by automatic plasma arc welding of the outer edges of the two flanges (Alexandre et al. 1987).

- Backfilled Gases, if any

- There are no special backfilled gases in the canister. Only air is in the sealed canister (Clark 1988b).

\section{- Handling Features}

- The flange on the filling nozzle of the canister is used for handling (Clark 1988b).

- All handling is automatic (Lund et al. 1987).

- Final Testing and/or Support Testing to Qualify the Waste Canister

- The only formal testing of the canister is smear testing for external contamination after cleaning externally with highpressure water and possibly acid to $0.001 \mathrm{Ci} / \mathrm{square} \mathrm{cm}$ (Alexandre et al. 1987; Lund et al. 1987).

4. Haste Disposal Container(s), if any

- The use of a disposal container remains to be determined in France.

5. Packing (or buffer) Materials

- The use of packing (or buffer) materials remains to be determined in France. However, clays are being investigated actively (Baudin et al. 1988). 
- Design Requirements and Function

- The requirements for any buffer materials are not yet specified, but studies are aimed at providing heat transfer and a seal between the canister (or disposal container) and the excavation in the host rock. The seal would prevent water from contacting the container and/or retard migration of radionuclides from the container. In addition, the buffer would help keep the container in place (Baudin et al. 1988).

- Materials of Construction

- Two natural clays available in France are under serious consideration: a sparnacian plastic clay (smectite 52\% and kaol in ite $48 \%$ ) with about $8 \%$ quartz, and an oligocene clay. A final dry specific gravity of about 1.5 is sought. A moisture content in the range of $10 \%$ is under consideration (Baudin et al. 1988).

- Filling of the final gap between the container and the buffer with a grout is being considered (Baudin et al. 1988).

- Shape and Dimensions

- Pre-pressing the buffer material into cylindrical blocks or part-cylinder blocks that would surround the waste canister in the disposal hole is under study (Baudin et al. 1988).

- Testing Requirements

- No information was found on packing testing requirements.

- Fabrication Technique

- Prefabrication by isostatic or unaxial pressing is under study, with the latter planned for future in situ tests (Baudin et al. 1988).

\section{Repository Interface}

- The repository concept remains to be determined in France but studies are underway (Baudin et al. 1988).

- Two families of disposal concepts are under study (Hoorelbeke et al. 1986).

- One concept is disposal in bore-holes in the floors of emplacement drifts with or without interim natural convection air cooling (such air cooling is being considered for interim storage to allow for a smaller repository for older waste). The holes with interim cooling would be 
large caissons with about 18 canisters. The holes without interim cooling would have one canister each.

- Another concept is disposal directly in disposal drifts with or without interim natural convection air cooling.

- Waste Package Handling, Storage, and Emplacement at Repository

- Vitrified HLW is being stored temporarily in natural air convection-cooled concrete caissons (with the canisters stacked nine high) in the storage facility at La Hague. This storage will be for the order of 20 years (Alexandre et al. 1987).

- Vitrified HLW will be transported to the repository waste receiving building (to be defined), with dry storage at the repository site for up to 20 or 30 years (Alexandre et al. 1987; Isaacs 1988).

- No information is available for handling at the repository because the concepts are currently being developed.

- Packing Handling and Emplacement

- Concepts under study for handling the packing material are a) assembling the container and packing in a metal basket and lowering the assembly into the disposal hole, and b) preemplacing the packing into the disposal hole, followed by emplacing the waste container (Baudin et al. 1988).

- Design Limits/Constraints by Repository (e.g., Dimensions, Weights, Temperatures, Areal Heat Loads, etc.)

- No information is available on the design constraints of the packing material by the repository.

- Dimensions and Spacing of Holes in Host Rock

- The reference disposal hole for study purposes is $1 \mathrm{~m}$ in diameter and $2.3 \mathrm{~m}$ deep. This arrangement would allow for $28 \mathrm{~cm}$ space between the waste container and the disposal hole (Baudin et al. 1988).

- Description of Liner of Holes in Host Rock, if any

- No information was found, but the implication is that there will be no liner (Baudin et al. 1988).

- Sealing Materials for the Emplacenent Holes and How Emplaced 
- No information was found on sealing materials for the emplacement holes.

- Retrievability Provisions, if any

- Retrievability requirements and provisions remain to be determined in France (IEAL 1987).

- Monitoring Provisions in Emplacement Holes, if any

- No monitoring provisions in the emplacement holes are developed yet. The general objective is to provide enough protection that no further human action is required after closure (IEAL 1987).

- Maintenance of administrative control over the repository area is desirable for several centuries (Goguel 1987). 


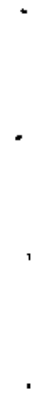

. 
WASTE PACKAGE PLANS IN THE FEDERAL REPUBLIC OF GERMANY

\section{Overall Scope/Strategy of Waste Package Concept}

- Overall Status of Repository and Waste Package Concept

- Germany plans to reprocess most of their spent fuel for recycle, and convert the HLW to borosilicate glass. However, they also plan to directly dispose of selected types of spent fuel that they don't plan to reprocess (e.g., THTR, GCR, LMFBR, MOX LWR fuels) that constitutes up to about $20 \%$ of their total spent fuel in the long run (Schneider et al. 1988; Weinlander 1988).

- The site at Gorleben is proposed for disposal of spent fuel and $H L W$. Acceptance of this site as a repository depends on results of extensive underground exploration. Shafts are being constructed for an underground research laboratory (Schneider et al. 1988).

- A concept of a production scale conditioning and encapsulation plant for direct spent fuel disposal was developed, and storage-transport-disposal canisters/casks are being developed (Luckscheiter 1987).

- Waste package concepts are still under development, but are relatively mature (Clark 1988b).

- Host Rock Material and Moninal Depth

- The proposed host formation is a salt dome, with the planned disposal depth at $870 \mathrm{~m}$ (Schneider et al. 1988).

\section{- Overall Waste Package Components}

- The overall waste package components for $H L W$ will be the vitrified HLW and the waste canister (FRG-US Workshop 3/88).

- The overall waste package components for spent fuel are consolidated spent fuel rods (or intact spent fuel assemblies or chopped spent fuel pins) a canister/cask, and a disposable transportation shielding overpack for gamma and neutrons (FRGUS Workshop 3/88).

- Regulatory Performance or Barrier Requirements (Waste Form, Canister and/or Container, Packing Around Container)

- No specific regulatory performance criteria exist (Clark $1988 b)$. 
- General criteria are defined in a 1982 safety code, "Safety Criteria for the Final Disposal of Radioactive Wastes in a Mine". The code specifies radiation protection criteria during disposal operations (along with other radiation protection ordinances) and during post-closure (IEAL 1987).

- A safety criteria document specifies qualitative criteria for the engineered and natural barriers. Quantitative criteria will be specified during the licensing and authorizing procedure for a site-specific review of the repository.

- Multiple barriers are required in the repository. These barriers are: waste form (the waste canister for HLW is not considered a barrier), repository, and overall geologic environment (IEAL 1987; Clark 1988b).

- Each barrier should provide "appropriate" isolation.

- The waste form and canister should provide the necessary level of containment during transport and handling.

- The "Pollux" waste package for transportation, storage and disposal of spent fuel has been assigned a design bas is of 500 years life expectancy.

- Container integrity may be required until near-field convergence of sait rock has encapsulated the waste package (from a few years for the borehole disposal concept to about 200 years for the disposal drift concept) (IEAL 1987;

Schneider et al. 1988).

- The maximum allowable dose to the most exposed member of public for unavoidable processes is $30 \mathrm{mrem} / \mathrm{yr}$. This dose applies to the operational phase and to the post-closure period (IEAL 1987).

- The maximum allowable dose to workers is the same as for reactor operations, or $5 \mathrm{rem} / \mathrm{yr}$ equivalent whole body dose (IEAL 1987).

- The maximum temperatures are to be $150-200^{\circ} \mathrm{C}$ at the salt/ canister interface (or $130^{\circ} \mathrm{C}$ if other minerals are present) (Schneider et al. 1988).

\section{- Requirements for Retrievability}

- Post-closure retrievability is not required, and is considered to be counter-productive to overall long-term safety of repository (IEAL 1987). 
- Regulatory Requirements for Quality Assurance (QA), Huclear Criticality

- QA requirements are developed by the waste product control authority (KFA at Jülich) for all radioactive wastes (Clark 1988b).

- HLW process streams are to be monitored by neutron flux measurements for fissile materials as generated, which will assure that all vitrified HLW will be outside nuclear criticality limits (Clark 1988b).

- No information was found on criticality control for spent fuel.

2. Haste Form [e.g., Borosilicate Glass (Monolithic or Other Form), Intact Spent Fuel Assemblies, Consolidated Spent Fuel Assemblies, etc.]

- Primary waste form will be HLW in vitrified borosilicate glass, with no more than 15\% waste oxides in glass (Schneider et al. 1988).

- The waste form for about $20 \%$ of spent fuel is spent fuel for which reprocessing is considered not to be practical (e.g., spent fue 1 from THTR, GCR, LMFBR, MOX in LWRs, etc.) (Weinlander 1988).

- Consolidated spent fuel rods for assemblies amenable to consolidation is preferred, some spent fuel will be packaged intact, and some may be chopped fuel rods (FRG-US Workshop $3 / 88)$.

- Anount and Configuration of Waste Form in a Package

- A total of 150 liters of borosilicate glass is in a cylindrical canister. The weight of glass is $360-400 \mathrm{~kg} /$ canister, and contains HLW from 1.25 MTU from France. About 0.91 to 1.15 MTU was to be in each canister from German reprocessing plants (Clark 1988b; Kuhn et al. 1986; Sombret 1985).

- Since the spring of 1989 decision to abandon reprocessing in Germany and to contract it to France and the U.K., the waste configuration will be the same as in France and the U.K.

- For spent fuel using the Pollux cask concept), the primary concept will have consolidated rods from eight PWR assemblies in four thin-walled, tubes called "bins". These tubes will be the shape of $1 / 4$ of the segment of a circle with a square cut out from the center of the circle. The filled tubes will be loaded vertically into the perimeter of the previously assembled storage-transport-disposal cask. Compacted fuel hardware in square tubes will be loaded into the center of the canister (Luckscheiter 1987; FRG-US Workshop 3/88). 
- Consolidation is envisaged as being done horizontally, one row of rods at a time that are placed in a horizontal trough with the same shape as a bin. When filled, one end of the trough will be mated to a bin and the rods will be pushed into the bin (FRG-US Workshop 3/88).

- An al ternative spent fuel disposal concept would use canisters approximately the same size as those for $\mathrm{HLW}$ $(0.43 \mathrm{~m}$ in outside diameter, $0.318 \mathrm{~m}$ in inside diameter, and $1.33 \mathrm{~m}$ long, including a foot ring at the base). In this case, the disassembled fuel pins would be cut into pieces about $1 \mathrm{~m}$ long and fed horizontally through a hole in the bottom of a canister with its lid al ready welded on. The total weight of spent fuel in one canister would be about 0.267 MTU from about 0.5 PWR assemblies. The total filled weight of a canister would be about 1.18 MT (Luckscheiter 1987; FRG-US Workshop 3/88; Clark 1988b).

- For spent fuel disposal of non-standard fuels, the amount and configuration of spent fuel will vary (Clark 1988b).

Type of Spent Fuel Source and Overview Description of Spent Fuel (or Reference to Description Information)

- Most spent fuels will be from PWRs and BWRs: uranium dioxide pellets in zircalloy rods, enriched to about $3.6 \% \mathrm{U}-235$ or greater (Clark 1988b).

- Some spent fuels will be from THTRs: uranium-thorium dioxide pebbles with a diameter of $6 \mathrm{~cm}$ and weight about 200 grams. Each pellet will contain 11.3 grams of heavy metal including 1.1 gram of uranium that is $93 \% \mathrm{U}-235$. The THTR-300 reactor produces about 170,000 pebbles/yr (Clark 1988b).

- Out-of-Reactor Age of the Spent Fuel or Haste

- The out-of-reactor age will be 5 to 10 years before reprocessing and HLW vitrification (Schneider et al. 1988).

- The age of LWR spent fuel at the time of packaging the fuel is expected to be 5 to 10 years, but the Pollux cask system can accept spent fuel after three years storage (Luckscheiter 1987).

- The age for mixed-oxide spent fuel is expected to be about 20 years out-of-reactor upon disposal (Clark 1988b).

- For HLW:

- The high-level waste canister will be the same as the French and U.K. HLW canisters. It contains 150 liters of glass in a 
total internal volume of 180 liters. The height of glass in the canister will be $1.04 \mathrm{~m}$. (Kuhn et al. 1985; Sombret 1985).

- The age of spent fuel will be 5 to 10 years out-of-reactor before reprocessing (with an average of about 7 years) and vitrification. The minimum age at disposal will be about 10 years (Schneider et al. 1988; Clark 1988b).

- Matrix Material, if any [Composition, Original Forra (e.g., Powdered Copper), and Identification of Matrixing Process]

- No matrix material is planned for either HLW or spent fuel (Schneider et al. 1988).

- Support Testing to Qualify the Waste Forre

- The quality of the borosilicate glass waste form will be controlled by control of vitrification process parameters (Clark 1988b).

3. Waste Canister (see Figures 1 and 5)

- Function(s) Provided by the Canister

- The functions provided by the HLW canister will be containment of waste during interim storage, transportation and associated handling through emplacement (Clark 1988b).

- The functions provided by the components of the Pollux cask/ canister will be: the inner spent fuel tubes (or "bins") in the Pollux cask/canister (they will have individual slip-over lids) will provide partial containment during lag storage before insertion into the disposal cask/canister/ overpack; the disposal cask/canister/overpack will provide sealing, protection against mechanical damage during subsequent handling, interim storage, transportation, and corrosion resistance after emplacement (FRG-US Workshop 3/88).

- For the alternative spent fuel disposal concept using HLW glass-sized canisters, the canister would provide encapsulation of cut-up spent fuel rods during storage, handling, transportation, and emplacement in the disposal facility (FRG-US Workshop 3/88).

- Design Requirements [e.g., Life Expectancy, Temperatures, Pressures (Including Hydrostatic or Lithostatic Pressures), Weights

(Including Waste Form), Criticality, Shielding]

- No information was found on the life expectancy of the French or U.K. canisters for high-level waste. 
- The French high-level waste canister weighs $70 \mathrm{~kg}$, and its glass contents weigh $360-400 \mathrm{~kg}$ (Sombret 1985).

- For HLW glass, there are no criticality limits (Clark 1988b).

- The Pollux storage-transport-disposal cask-canister-overpack has a design basis and an expected life of about 500 years in salt. It must withstand the lithostatic head of about 300 atmospheres. The design bas is temperatures are $300^{\circ} \mathrm{C}$ maximum for emplaced spent fue 1 and $150-200^{\circ} \mathrm{C}$ maximum surface temperature for the disposal package. The empty canister/cask/ overpack will weigh $57.8 \mathrm{MT}$ and the loaded canister/cask will weigh 65 MT. The design surface dose rate is less than 20 $\mathrm{mrem} / \mathrm{hr}$ (US-FRG Workshop 3/88; Clark 1988b).

- The alternative canister for cut-up spent fuel rods will weigh about $1.18 \mathrm{MT}$ when loaded, and will have a surface dose rate of about $1000 \mathrm{mrem} / \mathrm{hr}$. It will withstand the lithostatic pressure (US-FRG Workshop 3/88; Clark 1988b).

- Shape and Dimensions

- The French HLW canister is $0.43 \mathrm{~m}$ diameter by $1.35 \mathrm{~m}$ long. The German HLW canister was to be a cylinder $0.43 \mathrm{~m}$ diameter by $1.33 \mathrm{~m}$ long, but will no longer be used (Schneider et al. 1988).

- For the Pollux concept for spent fuel, the thick-walled cylindrical canister-cask-overpack will be 0.1542 m outside diameter by $5.462 \mathrm{~m}$ long (FRG-US Workshop 3/88; Clark 1988b).

- The alternative concept for spent fuel uses canisters approximately the same size as that for HLW $(0.43 \mathrm{~m}$ outside diameter, $0.318 \mathrm{~m}$ inside diameter by $1.33 \mathrm{~m}$ long, including a foot ring at the base) (Clark 1988b).

- Wall Thickness and Corrosion Allowance

- The thickness of the French and U.K. HLW canisters, the wall thickness is $5 \mathrm{~mm}$ (including the lids), with no corrosion allowance (Clark 1988b).

- For the reference Pollux canister/cask for spent fuel, the steel walls will be $15 \mathrm{~cm}$ thick with an $8 \mathrm{~mm}$ coating of Hastelloy $\mathrm{C4}$. The transportation shielding overpack will have additional thick walls of polyethylene (approximately $100 \mathrm{~mm}$ thick) and iron (FRG-US Workshop 3/88; Clark 1988b).

- The alternative concept for spent fuel rods in canisters would have walls that are $50 \mathrm{~mm}$ thick, with a coating of corrosion-resistant material (Clark 1988b). 
- Material of Construction

- The French HLW canister is made of a special stainless steel designated Z 15 CN 24-13 (Sombret 1985).

- The reference Pollux canister/cask for spent fuel will be made of $15 \mathrm{Mn}-6.3 \mathrm{Ni}$ steel with an external coating of Hastelloy C4 that is applied by plasma hot wire surfacing. The transportation shielding overpack will be made of ductile cast iron (GGG 40) lined with polyethylene for neutron shielding (FRG-US Workshop 3/88).

\section{- Closure Description and Process}

- The French canister lid is inverse hat-shaped. All but the flange of the lid fits into the filling nozzle of the canister. In France, sealing of the lid to the canister is done by automatic plasma arc welding of the edges of the two flanges (Sombret 1985).

- The first "primary" lid of the Pollux cask/canister for spent fuel will be sealed (gas-tight) by screwing into the inner canister while the assembly is in a hot cell. Above that, another "secondary" lid will be placed, and the assembly will be removed from the hot cell and sealed by welding in a welding gantry with the canister-cask-overpack on a turntable. The final lid in the shielded transportation overpack will be closed (weather-tight only) by screwing in its lid (FRG-US Workshop 3/88).

- All welding QA will be carried out by control of welding parameters (Clark 1988b).

\section{- Backfilled Gases, if any}

- No special gases will be backfilled. Only air will be in the sealed canister (Clark 1988b).

- Helium will be backfilled in the Pollux package (Clark 1988b).

- Handling Features

- The flange on the filling nozzle of the HLW canister (Germans call it a "pintle") will be picked up by a fingered grappling tool on the crane (Clark 1988b).

- For the Pollux cask system, the inner canister/cask will have no special handling features. It will be placed inside the transportation shielding overpack before it is taken into a hot cell (FRG-US Workshop 3/88). 
- The transportation shielding overpack will have two trunnions on each side (four trunnions total) near its top and bottom ends for handling.

- Final Testing and/or Support Testing to Qualify the Haste Canister

- The seal quality of the HLW canister will be assured by control of welding parameters in France and the U.K. (Clark 1988b).

- The HLW canister will be cooled, smear-tested for contamination, decontaminated as needed, and dimension checked (Schmidt et al. 1988).

- Gamma scanning of the HLW canister for determination of glass fill level is being considered (Clark $1988 \mathrm{BE}$ ).

- Built-in monitoring provisions for the HLW canister are not planned but may be possible (Clark 1988b).

4. Waste Disposal Container(s), if any (see Figure 5)

- In the concept with vitrified high-level waste, the canister will also serve as the disposal container (Clark et al. 1988).

- In the reference Pollux canister-cask-overpack concept for spent fuel disposal, the Pollux cask/canister and the overpack of polyethylene-lined nodular cast iron (not leak tight) will be an integral unit and serve also as the disposal container (FRG-US Workshop 3/88).

- Function(s) Provided by the Disposal Container

- For the reference Pollux concept for spent fuel disposal, the inner canister/cask serves as the hermetically sealed disposal container. The polyethylene-lined overpack will provide for handling, shielding, weather-tight prevention of outside materials from contacting the canister/cask during handling, transport, interim storage, and emplacement. The overpack will also provides some structural resistance to collapse after disposal (Clark 1988b).

- Design Requirements [e.g., Life Expectancy, Temperatures, Pressures (Including Hydrostatic or Lithostatic Pressures), Heights (Including Waste Form), Criticality, Shielding]

- The reference Pollux cask-canister-overpack will weigh 65 MT loaded, and its rail-mounted, mine vehicle and weigh another 15 MT (FRG-US Workshop 3/88).

- For other information on the "disposal container", see Section 3, above. 


\section{Packing (or Buffer) Materials}

- No packing or buffer material is planned for either concept (CTark 1988b).

- The backfill is planned will be crushed salt previously excavated from the disposal horizon (Clark 1988b).

6. Repository Interface (see Figure 6)

- Haste Package Handling. Storage, and Emplacement at Repository

- High-level waste canisters will be transported dry in transportable storage casks, and Pollux casks containing spent fuel will be transported by rail to the nearest terminal, then off-loaded onto a special heavy-haul truck for the remainder of the trip to the repository (Clark 1988b).

- High-level waste canisters will be unloaded in a waste receiving building where the casks will be unloaded dry through the bottom port in a hot cell. The unloaded canisters will be moved either to an air-cooled interim storage area (to reduce the heat/load to about $1.6 \mathrm{~kW} / \mathrm{canister)}$ or to the waste handling shaft area and loaded into a shielded container that will hold one can. The shielded container will be lowered through the shaft and transported to the emplacement room where the canister will be lowered by a cable into the disposal borehole. If the emplaced canister surface temperature is greater than about $160^{\circ} \mathrm{C}$, dumny canisters may be used as spacers between HLW canisters (Clark 1988b).

- For the reference Pollux concept for spent fuel disposal, interim storage at the repository will be in dry air. The Pollux canister-cask-overpack is received at the wastereceiving facility by rail or truck. After inspection, the cask will be lifted in the horizontal position and placed horizontally on a special waste emplacement rail car which is moved to the top of the mine shaft and lowered to the mine disposal horizon. The rail vehicle will be moved by a mine locomotive to the emplacement $\mathrm{drift}$. At the emplacement location, the total Pollux cask will be lifted from the vehicle by an emplacement crane and lowered onto the floor of the emplacement drift. The vehicle will then be returned to the surface for another cask load (FRG-US Workshop 3/88).

\section{- Packing Handling and Emplacement}

- No packing/buffer is planned to be used. Only structural backfill made of crushed salt previously excavated from the disposal horizon will be used to backfill the holes and drifts (Clark 1988b). 
- For emplacement of the Pollux canister-cask-overpack with spent fuel, backfill will be emplaced over each unit immediately after the cask has been emplaced. Two backfill

emplacement techniques are being studied: slinging or throwing (generally preferred), and pneumatic backfilling (FRG-US Workshop 3/88).

- Design Limits/Constraints by Repository (e.g., Dimensions, Weights, Temperatures, Areal Heat Loads, etc.)

- The maximum near-field salt temperature will be limited to $200^{\circ} \mathrm{C}$ (KfK 7/87).

- Creeping closure of salt around the HLW canisters is expected to seal the waste in a period of months, and around the Pollux containers in about 200 years, respectively (IEAL 1987;

Schneider et al. 1988).

- Dimensions and Spacing of Holes in Host Rock

- High-level waste canisters are to be stacked vertically in boreholes $0.70 \mathrm{~m}$ in diameter and 300-600 $\mathrm{m}$ deep (50-60 m apart) in gallery floors. Approximately 225 to 450 canisters will be emplaced in each hole (Schneider et al. 1988; Clark 1988b; NEA 1988).

- Spent fuel in Pollux casks will be emplaced horizontally in emplacement drifts, oriented end-to-end, with the ends about $3 \mathrm{~m}$ apart (FRG-US Workshop 3/1988).

- Spent fuel in HLW-type canisters would be emplaced vertically in boreholes the same as HLW canisters (FRG-US Workshop $3 / 88)$.

- Description of Liner of Holes in Host Rock, if any

- No liners are planned to be in disposal boreholes or in disposal drifts (Clark 1988b).

- Sealing Materials for the Emplacement Holes and How Emplaced

- The top $10 \mathrm{~m}$ of each borehole will be sealed with a plug of unknown materials after each borehole is filled (FRG-US Workshop 3/88).

- Backfill drifts will be filled with crushed rock salt, and sealed off from other chambers with clay and concrete dams (Schneider et al. 1988; FRG-US Workshop 3/88). 
- Retrievability Provisions, if any

- Retrievability is planned to end once an emplacement gallery has been backfilled and sealed. Retrievability is considered to compromise the isolation objective of the repository and is counter-productive (IEAL 1987).

- Monitoring Provisions in Emplacement Holes, if any

- Pre-closure monitoring of air and water in the disposal facility will be carried out to protect the workers (IEAL 1987).

- Post-closure surveillance is planned for some time period, limited to ordinary environmental protection requirements (Schneider et al. 1988).

- Human intrusion is not considered to be a matter of great concern (IEAL 1987). 


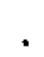

. 


\section{WASTE PACKAGE PLANS IN SWEDEN}

\section{Overall Scope/Strategy of Waste Package Concept (NEA 1988).}

- The Swedish repository concept was developed as a reference to satisfy the requirement of showing that safe waste disposal is feasible.

- The concept is intentionally conservative.

- The concept depends on multiple barriers. It is unique in that it uses a long-lived package ( $\mathrm{jt}$ is expected to last up to perhaps $1,000,000$ years), and places most of the reliance of post-closure safety on the waste package.

- Alternatives to the reference are being studied.

- Overall Status of Repository and Waste Package Concept (NEA 1988).

- Sweden does not plan to reprocess, but will dispose of spent fuel directly. Sweden had contracted some spent fuel to be reprocessed abroad, but is trading the resultant HLW for spent fuel, and is selling the contractual rights for reprocessing (IEAL 1987).

- Sweden will dispose of their spent fuel in a single deep geologic repository.

- Sweden plans to phase out all nuclear power by 2010, and their total quantity of spent fuel will be about 7800 MTU.

- The repository and waste package concepts for spent fuel have been developed since 1983, and have received much R\&D.

- Relatively few changes have occurred in the reference repository concept since its inception.

- The final repository concept will be selected about year 2000 .

- An underground research facility in granite has been used for research (Stripa facility) since 1977.

- A new underground research facility will be started up in 1993 in a representative host rock formation to study details of repository disposal.

- Investigations for repository sites have been carried out since 1977. 
- The site for a spent fuel disposal facility is expected to be characterized by 1998 . Construction of the repository is planned to start in 2010, and operation of the repository is planned to commence in 2020 .

- Fuel channels from BwR spent fuels, poison rods from PwR fuel assemblies, reactor internals, and other long-lived wastes will be disposed of at the same site as spent fuel, but in a separate repository.

\section{- Host Rock Material and Mominal Depth}

- The host rock is to be Pre-Cambrian crystalline rock in granite or gneiss or gabbro at a depth of about $500 \mathrm{~m}$. Selection of candidate host rocks was made after surveying potential rock formations in Sweden (NEA 1988).

- Overall Waste Package Components (NEA 1988).

- The overall waste package components will be spent fuel, a canister, a buffer/packing material, and the host rock.

- Unconsolidated spent fuel assemblies are to be embedded in lead matrix or pressed copper powder.

- A thick-walled canister is planned to be used.

- Compacted bentonite "donuts" are planned to be emplaced around the canister.

- Regulatory Performance or Barrier Requirements (Waste Form, Canister and/or Container, Packing Around Container)

- Formal specific performance requirements are not set by regulatory authorities for nuclear facilities. It is up to the nuclear industry to demonstrate compliance with general regulatory safety goals; thus, specific requirements for each barrier are not set by the regulators (IEAL 1987).

- The general radiation protection criterion for post-closure of a repository is that the contribution to the radiation dose to the most highly exposed public group shall be only an insignificant part of the dose from natural background and shall lie within the natural range of variation (NEA 1988).

- The dose limit for the first 1000 years or until the first period of glaciation is a maximum of $10 \mathrm{mrem} / \mathrm{yr}$ to the most exposed group (NEA 1988).

- For the time period after 1000 years, dose limits are being developed, and are expected to be based on a 
comparison of calculated releases with natural releases from weathering of the bedrock (NEA 1988).

- For time periods greater than about 10,000 years, predictions are considered to be relatively difficult, so limits beyond that time will not be considered. However, performance expectation over periods of millions of years should be estimated (SKB-3 Sumary p. 55; IEAL 1987).

- The occupational dose limits in a repository during operation are to be $5000 \mathrm{mrem} / \mathrm{yr}$ (NEA 1988).

- Requirenents for Retrievability

- No regulatory requirements are placed on retrievability (IEAL 1987).

- Regulatory Requirenents for Quality Assurance (QA). Nuclear Criticality

- There are no specific regulatory requirements for QA, but stringent QA will be applied to provide assurance that there are no deviations from the desired quality that could significantly impair the system safety (NEA 1988).

- A systematic quality control program, as typically done in nuclear activities and in the Swedish LLW-ILW disposal system, will be applied to the design, manufacture and construction of the various parts of the system (NEA 1988).

- Nuclear criticality in the repository is considered to be beyond the realm of reasonable possibility. If criticality should occur, the reaction is expected to stop when the water boils away, resulting in only local effects (SKB-3 Report, Summary 1983).

2. Waste Form [e.g., Borosilicate Glass (Monolithic or other Form), Intact Spent Fuel Assemblies, Consolidated Spent Fuel Assemblies, etc.]

- The waste form will be intact spent fuel assemblies from PWRs and BWRs (SKB-3 Report, Summary 1983).

- Amount and Configuration of Waste Form in a Package

- In the reference concept, eight BWR assemblies or two BWR pIus two PWR assemblies are to be held by spacers while the canister is being filled with molten lead. An alternate concept would involve filling the canister (containing nine BWR assemblies) with powdered copper followed by hot isostatic pressing into a solid body of copper. The alternative concept 
is considered to be easier to implement and would circumvent the potential toxicity issue accompanying the use of lead (NEA 1988).

- Approximately 1.4 MTU will be in each reference package. The reference lead-filled canister will emit about $0.8 \mathrm{~kW}$ of heat at time of emplacement (KBS-3 Report 1983; NEA 1988).

- Some spent fuel will be "non-standard", such as MOX spent fuel (NEA 1988).

- Fuel channels from BWR assemblies and poison rods from PWR assemblies will be removed before encapsulation of the spent fuel. These pieces will be placed in a rectangular concrete box that is back filled with concrete and disposed in a separate geologic repository at the same site (NEA 1988).

- Type of Spent Fuel Source and Overview Description of Spent Fuel (or Reference to Description Information)

- Spent fuel will be from PWRs and BWRs (KBS-3 Report, General 1983).

- For design purposes, the reference fuel is taken to be PWR fuel with an average burnup of 38,000 MWD/MTU, and a maximum burnup of 40,000 MWD/MTU (KBS-3 Report, General 1983).

- Out-of-Reactor Age of the Spent Fuel or Haste

- Spent fuel is stored in water pools at power plants for one to five years, then transferred to the central intermediate storage facility (CLAB) for 30-40 years in water pools before disposal (NEA 1988).

- The aging of spent fuel is desired to allow for cooler repository temperatures and for more efficient repository design.

- Central storage of spent fuel was selected based on economics.

- Wet storage of spent fuel was selected based on available technology and experience at the time (late 1970s), and based on keeping the fuel temperature and fuel degradation low.

- Underground storage was selected to provide protection from outside disturbances (at no extra cost compared to surface storage). 
- For HLH:

- There will be no HLW disposed of in Sweden. Only spent fuel will be disposed of (NEA 1988).

- Matrix Material, if any [Composition, Original Form (e.g., Powdered Copper), and Identification of Matrixing Process]

- Two matrix materials and manufacturing methods have been studied. In the reference method, the air-dried spent fuel will be placed in a spacer assembly in a prefabricated copper canister. The canister with spent fuel, mounted on a cart, will be taken to a casting cell where the canister and contents are placed inside a heated vacuum chamber, evacuated or filled with nitrogen, heated to about $400^{\circ} \mathrm{C}$, and the voids are filled with molten lead. The canister will be taken to another cell for air cooling over about four days. Then the canister will be taken to the welding cell where the canister opening is machined to specifications, and a tight-fitting lid is placed over the canister closure opening and welded on by means of electron beam welding (KBS-3 General 1983; NEA 1988).

- In the second (alternative) method for incorporating spent fuel in a matrix material, the air-dried spent fuel will be placed in spacers in a prefabricated copper canister. The canister with spent fuel, mounted on a cart, will be taken to a hot cell where the filling and pressing occurs. This alternative canister with spent fuel will be filled with copper powder. An air-tight cover plate with an evacuation tube will be placed inside the canister opening and seal welded to the canister. Hydrogen gas will be purged through the canister to reduce the oxygen content, then the canister will be evacuated and the tube sealed and cut. The primary copper lid will be placed in position and the canister placed inside a heated pressure vessel. After hydrogen purging of the joint surfaces between the canister and the lid and between the lid and the second container, the pressure vessel will be heated to $500^{\circ} \mathrm{C}$ and pressurized with argon gas at 1500 atmospheres. The copper will thereby be transformed to solid copper and the lid will be tightly joined to the canister (KBS-3 Report, General 1983.

- This second method for incorporating spent fuel in a matrix is considered to be easier to implement than the reference concept and it circumvents the toxicity issues associated with metallic lead. Full-scale tests have been carried out with both methods with good results (KBS-3 Summary p. 27; NEA 1988).

- The lead or copper matrix is to provide for crush resistance, good heat transfer, shielding, and for long-term durability. 
The copper canister is to provide for long-term durability (KBS-3 Report, Barriers 1983).

- Support Testing to Qualify the Waste Form

- Sweden has had a major R\&D program for many years to characterize spent fuel interactions in the canister and in their planned disposal environment (Forsyth et al. 1987).

\section{Waste Canister (see Figure 7)}

- Function(s) Provided by the Canister

- The canister is to contain the spent fuel and prevent dispersal of radioactive substances with the groundwater, to provide shielding of personnel during handling, and to provide shielding of rock and groundwater after emplacement (KBS-3 Report, Barriers 1983]

- Design Requirements [e.g.., Life Expectancy, Temperatures, Pressures (Including Hydrostatic or Lithostatic Pressures), Weights (Including Waste Form), Criticality, Shielding]

- The canister is expected to last about one million years (SKB3 Report, Barriers 1983).

- Copper is the present choice for the canister wall because it is the noblest of the common metals and is highly corrosion resistant. However, other materials, e.g., carbon steel, ceramics, are continuing to be studied (NEA 1988).

- The thick canister shields ground water from a high radiation dose that might cause electrolytic decomposition of ground water (NEA 1988).

- The external pressure on the canister will depend on the hydrostatic pressure at the disposal horizon and on the swelling pressure of the bentonite buffer material (NEA 1988).

- The internal pressure from helium will gradually build up to about 150 atmospheres (NEA 1988).

- Shape and Dimensions

- The canister will be cylindrical, $0.8 \mathrm{~m}$ outside diameter and $4.5 \mathrm{~m}$ long: the total weight of the reference lead-filled canister will be 22 MT (2.0 MT $\{1.4$ MTU $\}$ of fuel assemblies, 10.5 MT of lead, and 9.5 MT of copper). The total weight of the alternative copper-filled canister will be 18.5 MT (2.3 MT \{1.6 MTU\} of fuel assemblies, 18.2 MT copper) (KBS-3 Report, General 1983; NEA 1988). 
- Wall Thickness and Corrosion Allowance

- The canister is to be made of copper with a wall thickness of $10 \mathrm{~cm}$. Corrosion pits are assumed to be five times the mean corrosion depth. A wall thickness of about $1 \mathrm{~cm}$ is expected to remain intact for more than one million years. If a pitting factor of 25 is encountered (i.e., the maximum found in foreign studies with a corrosion environment much more severe than expected in the repository), a wall thickness of $6 \mathrm{~cm}$ would have an expected service life of more than one million years (KBS-3 Report, Sunmary 1983).

- Material of Construction

- The canister material is planned to be unalloyed copper (KBS3 Report, Barriers 1983).

- Closure Description and Process

- After cooling, the reference canister with a lead matrix is to be taken on a cart to an air cooling cell, then to the welding cell where the top surface of the lead will be machined smooth. A tight-fitting lid will then be placed over the canister closure opening and welded on by means of electron beam welding. After ultrasonic testing of the weld, the weld area will be machined smooth (KBS-3 Report, General 1983).

- The alternative canister with a copper matrix would be taken on a cart to the cell where the hot isostatic pressing is to be done. The isostatic pressing would be carried out as described above in Section 2, Waste Form, Matrix. The sealing of the lid would be accomplished by the hot isostatic pressing process (KBS-3, General 1983).

- Backfilled Gases, if any

- No special backfilled gases are planned to be in the reference canister with lead matrix. Only air will be in the canister (KBS-3 Report, General 1983).

- The alternative canister with a copper matrix would be backfilled with argon (KBS-3 Report, General 1983).

- Handling Features

- The top of the canister will have a slightly larger diameter (i.e., like a flange) than the canister. It is planned to be 
used for lifting the canister. The lid will have a recessed partial hole in its center for inserting a special tool for lifting (KBS-3 Report, General).

- Final Testing and/or Support Testing to Qualify the Waste Canister

- Strict quality control is to be imposed on the construction materials (chemically, metallographically, structurally, and visually) and the fabrication processes (dimensionally, ultrasonically for joints, and visually). Control of process parameters is expected to assure the quality of the matrixing processes and the lid sealing processes (KBS-3 Report, Barriers 1983).

- The final weld will be checked ultrasonically. The external surfaces of the canister will be checked for contamination and decontaminated if necessary (KBS-3 Report, General 1983).

4. Waste Disposal Container(s), if any

- No separate disposal container or overpack is pianned. The copper canister will also serve as the disposal container (NEA 1988).

\section{Packing (or Buffer) Materials}

- Design Requirements and Function

- The buffer/packing material is expected to provide impermeability to prevent water from reaching the canister. It will provide a seal to the canister by swelling when wet, and will provide good ion exchange properties in event radionuclides leak from the canister. It will also provide plasticity to protect the canister in the event of rock movements (NEA 1988).

- 8ackfill material for drifts are expected to provide good sorption characteristics and good structural support for the excavations (NEA 1988).

- Materials of Construction

- Buffer/packing is planned to be placed in disposal boreholes as pressed bentonite blocks (primarily smectite) with a specific gravity of 2.1-2.2. The gaps between the pressed bentonite and the canister (about $10 \mathrm{~mm}$ ) and the borehole wall (about $50 \mathrm{~mm}$ ) are to be filled with bentonite powder with a specific gravity of about 1.2. The top $1 \mathrm{~m}$ of each disposal borehole will be filled with backfill material after removing the temporary water-tight seal (KBS-3 Report, Barriers 1983; NEA 1988). 
- Backfill of drifts and the top $1 \mathrm{~m}$ of each borehole will be $90 \%$ sand $/ 10 \%$ bentonite as a granular mixture. Its specific gravity is expected to be about 1.8-2.2 after compaction, and about 1.1-1.8 for the hydraulically emplaced backfill (KBS-3 Report, Barriers 1983; NEA 1988).

- Shape and Dimensions

- The pressed buffer/packing pieces are to be donut shaped with a radial thickness of $0.3 \mathrm{~m}$ between the canister and rock. The outer diameter/inner diameter of the donuts will be $1.5 \mathrm{~m}$ and $0.9 \mathrm{~m}$, respectively (NEA 1988).

- The dish-shaped blocks of buffer material are to be placed above ( $1.5 \mathrm{~m}$ thick) and below $(0.5 \mathrm{~m}$ thick) the canister (NEA 1988).

- The powdered bentonite to be placed between the pressed bentonite and the canister and borehole walls will be about $10 \mathrm{~mm}$ and $50 \mathrm{~mm}$ thick, respectively (KBS-3 Report, Barriers 1983).

- The planned backfill material will be loose and granular (NEA 1988).

- Testing Requirements

- The calcium, the sulphides, and the organic matter content of the bentonite will be measured to keep them to acceptably low values (KBS-3 Report, Barriers 1983).

- Fabrication Technique

- The buffer/packing material as fitted blocks will be formed by isostatical pressing under a pressure of about 100-1,000 atmospheres. Oonuts will then be made by drilling out the centers. The powdered buffer filler material will be sized for its application (KBS-3 Report, Barriers 1983; Hanke 1987).

- The backfill materials for the drifts will be mechanically mixed before emplacement (NEA 1988).

\section{Repository Interface (see Figure 8)}

- The repository will consist of a series of parallel drifts at the reference depth of $500 \mathrm{~m}$ with disposal boreholes in the floors of the drifts. Disposal drifts will be inverted U-shaped, with a flat floor, and will be $3.3-\mathrm{m}$ wide and $4.5-\mathrm{m}$ high overall. The disposal drifts may be at one or two levels of depth with an elevation difference of about $100 \mathrm{~m}$ and a minimum distance to significant fractures of $100 \mathrm{~m}$ (KBS-3 Report, General 1983). 
- Waste Package Handling, Storage, and Emplacement at Repository

- Spent fuel has been shipped from reactor pools to the central pool storage facility (CLAB) since 1985 by a special transport ship (with intermodal heavy-haul trucks for land transport) using TN-17/Mk 2 dry transport casks (loaded weight 80 MT or 88 tons with 17 BWR fuel elements or six PWR fuel elements) with a nitrogen cover gas at 0.5 atmosphere. After placing the cask in the unloading pool and removing the outer lid, the vertically-oriented cask is mated to a subfloor in an isolated pool compartment and the inner lid is removed. Spent fuel is removed and placed in portable fuel racks. The racks (with five PWR assemblies or 16 BWR assemblies) are then moved to their interim storage positions in one of the storage pools. When ready for disposal, the spent fuel will be reloaded into the same casks and shipped to the repository (KBS-3 Report, General 1983; NEA 1988).

- Spent fuel will be received at the repository from the interim storage facility with essentially the same handing procedure as in the CLAB. It will be unloaded under water at the surface facility at the repository site. The spent fuel assemblies will be placed in portable racks and moved to an adjacent lag storage pool. The fuel channels of BWR fuels and poison rods from PWR fuels will be removed under water and moved to a separate facility for their encapsulation. The spent fuel assemblies will then be taken to an air-atmosphere dry hot cell for encapsulation (KBS-3 Report, General 1983; NEA 1988).

- For encapsulation, see Item 2 above (Waste Form, Matrix material).

- Each disposal-ready canister will first be moved to an aircooled lag storage area. When ready for disposal, the canister will be placed vertically in a shielded transporter on a cart, taken to the shaft, and lowered into the disposal area (KBS-3 Report, General 1983).

- Each canister will be picked up by an emplacement vehicle with a shielded container at the bottom of the elevator at the repository level. The emplacement vehicle will tilt the canister to the horizontal position, move to the emplacement hole, tilt the canister to vertical, then lower the canister into the hole. After the canister is in place, the vehicle will leave and additional buffer material will be placed in the hole using a buffer emplacement truck (KBS-3 Report, General 1988; NEA 1988). 
- Packing Handling and Emplacement

- Before drilling an emplacement hole, a small core hole will be drilled from which a judgment is made about the suitability of the location based on water conductivity of the core. After suitability is confinmed, the larger hole will be drilled (KBS-3 Report, General 1983; NEA 1988).

- Before emplacing a canister in its hole, the compressed bottom circular rings and annular rings of the buffer material will be added to the hole and a temporary funnel-like steel guide is inserted over the top bentonite ring, using a special truck. After emplacement of the waste canister, the bentonite placement vehicle will place the top bentonite discs over the canister (NEA 1988).

- A temporary water-tight seal will be placed over the emplacement hole after it is filled with the waste canister and the compacted buffer material. This water-tight seal will be removed before final backfill of the emplacement drift (NEA 1988).

- The backfill for the emplacement drifts will be emplaced and compacted mechanically in layers. The top of the backfill in each drift will be emplaced pneumatically (NEA 1988).

- Design Limits/Constraints by Repository (e.g., Dimensions, Meights, Temperatures, Areal Heat Loads, etc.)

- External pressures on the canister will depend on hydrostatic pressure and on bentonite swelling pressure. Swelling pressures are expected to be about 100 atmospheres (KBS-3 Report, Barriers 1983; NEA 1988).

- Rock and bentonite temperature limits are set at $80^{\circ} \mathrm{C}$. The ambient temperature of the rock is assumed to be $15^{\circ} \mathrm{C}$. The temperature limit was selected to provide chemical stability and durability of the bentonite (expected to be stable for about 1 million years at $100^{\circ} \mathrm{C}$ ) with a $20^{\circ} \mathrm{C}$ allowance. Also, the lower temperatures should minimize thermal and structural effects on the rock and bentonite, and reduce thermal convection of ground water to insignificant levels (KBS-3 Report, General 1983; NEA 1988).

- Dimensions and Spacing of Holes in Host Rock

- Emplacement holes are to be $1.5 \mathrm{~m}$ diameter and $7.5 \mathrm{~m}$ deep, and will be drilled in the floors of the tunnels (about $6 \mathrm{~m}$ apart). Disposal tunnels are to be about $25 \mathrm{~m}$ apart for a 
one-level repository and $33 \mathrm{~m}$ for a two-level repository. One waste canister will be placed in each hole (KBS-3 Report, General 1983; NEA 1988).

- Description of Liner of Holes in Host Rock. if any

- No liner will be in the emplacement holes, according to illustrations (KBS-3 Report, General 1983).

- Sealing Materials for the Emplacement Holes and How Emplaced

- Backfill of the tunnels is to be with a mixture of $90 \%$ sand and $10 \%$ bentonite. The top of each emplacement hole is also to be filled with this material after removal of the temporary water-tight plug. Gaps in emplacement holes are to be backfilled with powdered bentonite. The main tunnels, shafts, and fracture zones are to be plugged with pressed bentonite blocks to minimize water infiltration (NEA 1988).

- Retrievability Provisions, if any

- There are no regulatory requirements for retrievability (IEAL 1987).

- In crystalline rock, the waste will be retrievable for a very long time because of the nature of the design, but special provisions for retrievability are not intentionally designed into the system. Retrievability is considered to be a matter of cost and keeping records. The alternative very deep borehole disposal concept at a depth of several thousand meters would not offer inherent retrievability (IEAL 1987; NEA 1988).

- Monitoring Provisions in Enplacenent Holes, if any

- Monitoring is not expected to be needed for long-term safety. However, a monitoring program may be valuable for scientific or other reasons. Also, requirements for markers have been discussed but not specified (IEAL 1987; NEA 1988). 
WASTE PACKAGE PLANS IN SWITZERLAND

\section{Overall Scope/Strategy of Waste Package Concept}

- Switzerland plans to dispose of waste as vitrified HLW, but the option of disposing of spent fuel is being kept open. Reprocessing of Swiss spent fuel is being done in other countries and is not foreseen in Switzerland; the decision for reprocessing of Swiss spent fuel was jointly agreed to by the utilities and the Federal government (NEA 1988).

- The waste package information for Switzerland is based primarily on the results in "Project Gewahr", a study completed in January 1985 to respond to the Federal government's mandate to guarantee the feasibility and safety of final disposal as a prerequisite to the extension of operational licenses of their nuclear power plants; in 1988 the Federal government determined that "Project Gewahr" had proven the feasibility of their HLW disposal concept, but was not yet convinced that a suitable host rock and site had been found (NEA 1988; Schneider et al. 1988).

\section{- Overall Status of Repository and Waste Package Concept}

- The repository and waste package concepts are conceptual, and are based on disposal in granite. Repository concepts for sedimentary rock are just starting to be developed. Supporting R\&D for geologic disposal has been carried out since the early 1980s, with emphas is on geologic R\&D. R\&D on engineering aspects of disposal has been modest since 1985. A study on the availability of sedimentary rock options was completed in 1988, and repository site selection is in progress. The most promising repository option is expected to be selected for further field investigations in 1989. By about 1992, a synthesis of the knowledge of the crystalline bedrock and sedimentary rock options will be possible, and thereafter, one site will be selected for detailed characterization. A Swiss repository for HLW and alpha-bearing wastes could be operational about 2025 (Kowalski et a1. 1988).

- An underground research laboratory in granite has been operated for several years (Schneider et al. 1988; Clark 1988c).

- The HLW repository will also be used for disposal of the small amounts of alpha-bearing wastes and intermediate-level wastes that exceed the radionuclide content for low-level waste disposal set by Swiss authorities. These wastes will be disposed of in a separate part of the repository using a different concept (NAGRA 1985; IEAL 1987). 
- Host Rock Material and Mominal Depth

- Crystalline rock (probably granite at about $1200 \mathrm{~m}$ ) or sedimentary rock (particularly clay and anhydrite at about $700 \mathrm{~m}$ ) are the candidate host rocks. These are considered to be the only potentially suitable host rocks available in Switzerland (Clark 1988c; NEA 1988).

- Overall Waste Package Components

- The overall waste package components will be the vitrified HLW, the canister, the disposal container, and buffer material (NEA 1988; NAGRA 1985).

- Regulatory Performance or Barrier Requirenents (Waste Form, Canister and/or Container, Packing Around Container)

- No specific overall or individual barrier performance requirements are set by regulations because that is believed to restrict flexibility. However, by consensus of all parties, multiple barriers are deemed to be required. It is the responsibility of the waste producers to show that the overall safety requirements are met (IAEL 1987; Schneider et a1. 1988).

- Key overall performance objectives for the repository as planned by NAGRA are: radionuclides from reasonably foreseeable post-closure processes and events for a disposal facility that reach the biosphere must not at any time lead to individual doses exceeding $10 \mathrm{mrem} /$ year. This dose rate is one-half of the operational limit for nuclear power plants because the effects from a repository could last longer and could spread farther than from a nuclear power plant; also, a repository must be designed so that at any time it can be sealed within a few years (NEA 1988; IEAL 1987).

- Requirements for Retrievability

- The overall performance objectives imply that retrievability should not be considered as a last safety resort. However, retrievability may be beneficial for socio-political reasons, and is not ruled out (NAGRA 1985; 1EAL 1987).

- Regulatory Requirements for Quality Assurance (QA). Nuclear Criticality

- Regulatory requirements for quality assurance and nuclear criticality have not yet been formulated (Clark 1988c). 
- Project Gewahr outlines a quality assurance program for the waste management system (from waste producers abroad or in Switzerland through receipt and emplacement of the waste) (NAGRA 1985).

2. Haste Form [e.g., Borosilicate Glass (Monolithic or Other Form), Intact Spent Fuel Assemblies, Consolidated Spent Fuel Assemblies, etc.]

- The waste form will be borosilicate glass with about 10 weight percent fission product plus actinide oxides (or about 13 weight percent waste oxides) (Sombret 1985; NEA 1988).

- Direct disposal of part of the spent fuel may be considered in the future. If direct disposal is to be used, other considerations such as consolidation and matrixing are yet to be decided (Clark 1988c).

- Amount and Configuration of Waste Form in a Package

- The configuration of $\mathrm{HLW}$ in a canister is the same as in France and the U.K., or 360-400 kg of monolithic borosilicate glass in a cylindrical canister (Sombret 1985).

- HLW from 1.25 to 1.31 MTU will be in one canister (Sombret 1985; NAGRA 1985).

- Type of Spent Fuel Source and Overview Description of Spent Fuel (or Reference to Description Information)

- Spent fuel is from conventional BWRs and PWRs (NAGRA 1985).

- Out-of-Reactor Age of the Spent Fuel or Haste

- The normal out-of-reactor time to disposal for HLW is about 40 or more years, based on keeping the repository from becoming too hot (IEAL 1987; NEA 1988; Kowalski et al. 1988).

- Spent fuel is to be stored in reactor storage pools for about 10 years. Supplemental centralized interim storage in dry Castor casks will be needed and constructed by about 1992 . Spent fuel will be shipped to France and the U.K. for reprocessing, with return of HLW incorporated into borosilicate glass beginning about 1992. The central interim storage facility will also be used for vitrified HLW (IEAL 1987; NAGRA 1985).

- For HLH:

- The fraction of filling of canister is the same as in France and the U.K., or $360-400 \mathrm{~kg}$ of monolithic vitrified HLW in 150 liters in a cylindrical canister with a total net volume of 170 liters (or 88\% full) (Sombret 1985). 
- The out-of-reactor age before reprocessing will vary but will be in the order of 10 years. The age at the time of disposal will be about 40 years (NEA 1988).

- Matrix Material, if any [Composition, Original Form (e.g.. Powdered Copper), and Identification of Matrixing Process]

- No matrix material other than borosilicate glass will be used for HLW (NEA 1988).

- If direct disposal of spent fuel is eventually done, the use of matrix materials is yet to be determined (Clark 1988c).

- Support Testing to Qualify the Waste Form

- In France and the U.K., the vitrified HLW quality is based on control of process parameters (Sombret 1985).

- Acceptance criteria for the waste form have not yet been developed. Thus, testing for qualifying the waste form is not yet developed (Clark 1988c).

3. Waste Canister (Because all reprocessing of Swiss spent fuel is to be done in France and the U.K., which have similar canisters, the canisters for Swiss HLW are the same as in France and the U.K.; see Figure 1)

- Function(s) Provided by the Canister

- The canister will provide for handling, containment during storage, and transportation and encapsulation in disposal containers (Clark 1988c).

- Design Requirements [e.g., Life Expectancy, Temperatures, Pressures (Including Hydrostatic or Lithostatic Pressures). Weights (Including Waste Form), Criticality, Shielding]

- The life expectancy of the canister was not found, but is implied to last through interim storage and encapsulation in a disposal container (author's note).

- No information was found on other requirements, but external pressures are not imposed on the canister in the reference concept (Clark 1988C).

- The weight of the empty canister will be $70 \mathrm{~kg}$ (Sombret 1985).

- Shape and Dimensions

- The canister will be a cylinder that measures $0.43 \mathrm{~m}$ in diameter by $1.335 \mathrm{~m}$ in overall height, including the filling neck and nozzle. The canister will have reverse head on the 
bottom, which allows for a stacking height of $1.285 \mathrm{~m}$. The gross canister internal volume will be 170 liters. The net volume of glass in the canister will be 150 liters. The empty weight of the canister will be about $70 \mathrm{~kg}$, and total the filled weight will be about 440-480 kg (Sombret 1985; CEC 1985).

- Hall Thickness and Corrosion Allowance

- The wall thickness of the canister will be 5 mon (Sombret 1985).

- There will be no corrosion allowance (Clark 1988b).

- Material of Construction

- The French canister will be a special stainless steel designated as Z 15 CN 24-13 (Sombret 1985).

- Closure Description and Process

- The canister lid will be inverse hat-shaped. The lid (except its flange) will fit into the filling nozzle of the canister. The flanges of the lid and filling nozzle will be welded together (Sombret 1985).

- The weld closure in France is done by automatic plasma arc welding of the outer edges of the two flanges (Alexandre et a]. 1987).

- Backfilled Gases, if any

- No backfilled gases will be used (i.e, ambient air only) (Clark 1988b).

- Handling Features

- The flange on the filling nozzle of the canister will provide for handling (Clark 1988a).

- All handling is automatic at the French vitrification plant (Lund et al. 1987).

- Final Testing and/or Support Testing to Qualify the Waste Canister

- In the French vitrification plant, the only testing is smear testing for external contamination after cleaning externally with high-pressure water and possibly acid to $0.001 \mathrm{Ci} / \mathrm{square}$ Cm (Alexandre et al. 1987; Lund et al. 1987). 
4. Waste Disposal Container(s), if any (see Figure 9)

- Function(s) Provided by the Disposal Container

- The disposal container will provide for a second containment of waste and partial shielding of personnel during emplacement and of buffer/backfill after emplacement, handling of waste between the surface storage facility and the repository mine, and containment of waste and structural integrity for at least 1,000 years after emplacement (Schneider et al. 1988; Clark $1988 \mathrm{c})$.

- Design Requirements [e.g., Life Expectancy, Temperatures, Pressures (Including Hydrostatic or Lithostatic Pressures). Weights

(Including Waste Form), Criticality, Shielding] (NEA 1988).

- The minimum lifetime of the disposal container in the repository is expected to be 1,000 years.

- The maximum disposal container wall temperature is expected to be $150^{\circ} \mathrm{C}$.

- The disposal container must withstand the external lithologic pressure, or up to about 300 atmospheres, depending on final repository conditions.

- Currently there are no weight or dimension limits on the disposal containers (Clark 1988c).

- Shape and Dimensions

- The disposal container will have a cylindrical shape, with the outer diameter measuring $0.94 \mathrm{~m}$ and an overall length of $2.0 \mathrm{~m}$. The final filled weight is expected to be 8.5 MT (NEA 1988).

- Wall Thickness and Corrosion Allowance

- The disposal container will be heavy enough to be selfsupporting in the repository environment. Its wall thickness will be $25 \mathrm{~cm}$ (NEA 1988; Schneider et al. 1988).

- The corrosion allowance for the HLW disposal container will be $5 \mathrm{~cm}$. The environment for the disposal container includes ground water, lithostatic pressure (up to 300 atmospheres), and elevated temperatures (up to $150^{\circ} \mathrm{C}$ ) (NAGRA 1985; Clark $1988 \mathrm{c}$ ). 
- Material of Construction

- The disposal container is planned to be made of corrosionresistant cast steel designated as GS 40 . Steel is considered to be as suitable as copper for corrosion resistance, but further research evidence on its suitability is required (Simpson et al. 1986; NEA 1988).

- Other materials under consideration are nodular cast iron (designated GGG 40), copper, titanium or titanium alloys, a nickel-chrome-molybdenum alloy, and alumina (Simpson et al. 1986).

- If direct disposal of some spent fuel is implemented, copper would be considered (Clark 1988c).

- Closure Description and Process

- A hemispherical lid (15 $\mathrm{cm}$ thick) will be pressed into the body of the disposal container. The flange of the lid and the cylindrical end of the disposal container are to be welded (NEA 1988; NAGRA 1985).

- Backfilled Gases, if any

- It is not yet determined if the container will be backfilled with special gases (Clark 1988c).

- Handling Features

- No information was found on handling features.

- Final Testing and/or Support Testing to Qualify the Waste Container

- The container quality before filling will be controlled by conventional fabrication control techniques. The welded joints are to be tested using ultrasonics. Other testing, if any, is yet to be determined (NEA 1988).

- Materials/Gas in Annular Gap Between the Canister and the Disposal Container or Between Containers, If More Than One

- No information was found on special gases in the annular space.

- Extra shielding is to be encased at each end of the canister within the disposal container (Clark 1988c). 
- Built-in Monitoring Provisions (e.g., Profile Scans, CEC Tomography)

- Built-in provisions for monitoring, if any, are to be determined (Clark 1988c).

\section{Packing (or Buffer) Materials}

- Design Requirements and Function

- The functions of the buffer will be to reduce water transport to the disposal container and radionuclide transport away from the container by sorption, to provide heat transfer from the disposal container, and to provide structural backfill of the disposal drifts (Clark 1988c).

- The life expectancy of the buffer material is about 500,000 years (Clark 1988c).

- The maximum temperature of the buffer material is currently limited to $150^{\circ} \mathrm{C}$ at the surface of the waste disposal container. Considerations are being given to reducing this temperature to minimize changes in the buffer material ( $\mathrm{Clark}$ 1988c).

- The maximum swelling and total pressure is not expected to exceed about 300 atmospheres (NEA 1988).

- Materials of Construction

- The buffer material is planned to be highly compacted bentonite around the disposal container. Specific gravities of the buffer material between 1.55 and 2.05 are being considered (Simpson et a1. 1986; NEA 1988).

- Shape and Dimensions

- The buffer material will be prefabricated blocks in the shape of annular circular segments for stacking within the circular disposal tunnels and around the disposal containers (NAGRA 1985).

- The total thickness of one or more blocks around each container is planned to be about 1.4 m (NAGRA 1985; NEA Brochure 1988).

\section{- Testing Requirements}

- Testing requirements and techniques are to be developed as needed (Clark 1988C). 
- No in-place monitoring systems are currently contemplated (Clark 1988c).

- Fabrication Technique

- The fabrication technique for the buffer material is not yet determined, but is under development in Switzerland (Clark 1988c).

\section{Repository Interface (see Figure 9)}

- Haste Package Handling, Storage, and Emplacement at Repository

- Canisterized and vitrified HLW will be received from the French and U.K. vitrification facilities after interim storage there in dry air-cooled vaults. The canisters will then be kept in interim storage in dry transportable storage casks in Switzerland for a few tens of years (NAGRA 1985; NEA 1988; Kowalski et al. 1988).

- After interim storage, the casks will be received at the waste reception and packaging facility and unloaded in a dry hot cell at the earth's surface. One HLW canister will be loaded into each disposal container which will be then sealed and prepared for emplacement. After lag storage for up to a few days, individual containers with waste wili be transported down a shaft to the repository disposal horizon in special shielded transporters and emplaced axially in the circular cross-section (3.7-m diameter) tunnels on prefabricated compacted bentonite blocks. The adjacent disposal containers will be separated by about $3 \mathrm{~m}$ (the centers of containers will be about $5 \mathrm{~m}$ apart). Disposal drifts at more than one depth level may be used (NEA 1988; NAGRA 1985; Clark 1988c).

- Packing Handling and Emplacement

- A specially designed remote handling machine, currently conceived to be on rails, will be developed for the bentonite blocks; the lower blocks will be emplaced before the waste containers are emplaced. The bentonite blocks in the upper half of the tunnel will be emplaced after the disposal container is emplaced (NAGRA 1985; NEA 1988; NEA Brochure 1988).

- Design Limits/Constraints by Repository (e.g., Dimensions, Weights, Temperatures, Areal Heat Loads, etc.)

- The maximum temperature in the centerline of the vitrified waste is estimated to be $195^{\circ} \mathrm{C}$ at 1.1 years after emplacement and about $115^{\circ} \mathrm{C}$ at 50 years after emplacement. The maximum temperature of the disposal container wall is estimated to be $153^{\circ} \mathrm{C}$ and in the bentonite to be $146^{\circ} \mathrm{C}$ after 1.1 years, and 
$100^{\circ} \mathrm{C}$ and $95^{\circ} \mathrm{C}$ at 50 years after emplacement, respectively. Maximum temperatures at the rock wall are estimated to be $76^{\circ} \mathrm{C}$ and $73^{\circ} \mathrm{C}$ after 1.1 and 50 years respectively (NEA 1988).

- The maximum total external pressure on the canisters is estimated to be about 300 atmospheres (NEA 1988).

- Dimensions and Spacing of Holes in Host Rock

- Disposal containers are to be lying horizontally in the tunnels and spaced $5 \mathrm{~m}$ from center to center (NEA 1988).

- Description of Liner of Holes in Host Rock, if any

- A hole liner is not applicable for the Swiss concept. 0isposal containers will be placed in the emplacement drifts with no boreholes (NAGRA 1985).

- Sealing Materials for the Emplacement Holes and How Emplaced

- Emplacement hole sealing is not applicable here because there will be no boreholes (NAGRA 1985).

- The horizontal-lying canisters will be surrounded by compacted bentonite blocks (NEA 1988; NAGRA 1985).

- Retrievability Provisions, if any

- The safety goal implies that retrievability should not be considered as a last safety resort. However, retrievability may be beneficial for socio-political reasons, and is not ruled out (NAGRA 1985; IEAL 1987).

- Retrievability provisions are not currently in the plans (Clark 1988c).

- Monitoring Provisions in Emplacement Holes, if any

- The goal of being able to seal the filled repository at any time within a few years after filling with the possibility of dispensing with safety and surveillance measures implies that long-term monitoring is not required. However, long-term monitoring is not ruled out (IEAL 1987). 


\section{WASTE PACKAGE PLANS IN THE UNITED KINGDOM}

\section{Overall Scope/Strategy of Haste Package Concept}

- Overall Status of Repository and Haste Package Concept (Schneider et al. 1988).

- The position in the United Kingdom is that a HLW repository will not needed before 2040, and there are advantages to letting the waste age. Safety in storage and transportation, however, warrant early stabilization of the high-level liquid wastes. Furthermore, they do not want to foreclose on disposal options until a disposal facility is available. Their strategy is under continual review (Feates 1987).

- Thus, the U.K. has postponed siting and developing a specific repository and waste package concept since 1981 until some indeterminate time in the future.

- A number of concepts were developed in the late 1970 s and early 1980s in granite, clay and salt, with essentially no work since then on any concept.

- The U.K. is carrying out generic R\&D, including field work, and performance assessment modeling studies in preparation for future repository needs. The U.K. had an underground research laboratory (with several boreholes up to $700 \mathrm{~m}$ deep) wherein they were studying the permeability of fractured granite at Troon, Cornwall in the early 1980s. They are closely monitoring work in other countries, and they are also participating in a number of multi-national projects to keep abreast of developments (Roberts 1987; IEAL 1987; Feates 1987).

- The U.K. is reprocessing spent fuel and will be converting high-level liquid waste (HLLW) to borosilicate glass using the French vitrification process starting about 1992.

- Host Rock Material and Mominal Depth

- An inventory of potential repository sites was completed in the early 1980s that led to sites with crystalline rock (particularly granite), clay, and evaporite rocks (anhydrite and sait). Most work in the U.K. has been on granite (Parker et a1. 1984).

- The disposal depth should be great enough to avoid inadvertent intrusion. A tentative minimum depth $300 \mathrm{~m}$ has been stated (Parker et a]. 1984; Bush et a1. 1987). 
- Overall Waste Package Components

- The overall waste package components are expected to be a monolithic borosilicate glass form, a canister, a disposal container, and buffer/packing material. However, decisions on final components will await later definition of the repository host geology (Parker et a1. 1984).

- Regulatory Performance or Barrier Requirements (Haste Form, Canister and/or Container, Packing Around Container)

- Detailed regulations for disposal have not yet been developed, and with the strategy to delay disposal, regulations are not expected to be developed in the near future (IEAL 1987).

- Multiple barriers are expected to be used, but no specific requirements have been developed (Fry et a1. 1982).

- The general thinking is that the container life should be sufficient to allow the decay of soluble species such as Cs137, $\mathrm{Sr}-90$ and $\mathrm{H}-3$ to levels comparable with the toxicity of actinides in the near-field groundwater, or in the order of about 500-1,000 years (Bush et al. 1987).

- The overall objectives for radioactive waste management limit the average effective dose equivalent from all sources to representative members of a critical group to no more than 500 mrem/year (IEAL 1987).

- The target for post-disposal risk to the most exposed individual is less than one in $1 \mathrm{mill}$ ion/year, or equivalent to 10 $\mathrm{mrem} / \mathrm{yr}$. In addition, proof of safety to this limit is required with no future time period specified (Roberts 1987).

- Requirements for Retrievability

- No requirements have been set at this time for retrievability of waste from a repository (IEAL 1987).

- Regulatory Requirements for Quality Assurance (QA), Nuclear Criticality

- No information was found on regulatory requirements for quality assurance and criticality.

2. Waste Form [e.g., Borosilicate Glass (Monolithic or Other Form), Intact Spent Fuel Assemblies, Consolidated Spent Fuel Assemblies, etc.]

- The waste form will be borosilicate glass (designated formulation "MW") with about 25 weight percent waste oxides, including about 
11 weight percent fission product oxides or about 15 weight percent fission product-plus-actinide oxides (Woodall et a1. 1987; Hough et al. 1987; Gowing et al. 1987).

\section{- Amount and Configuration of Haste Form in a Package}

- The configuration will be essentially the same as the cylindrical shape in France (Woodall et al. 1984).

- $400 \mathrm{~kg}$ of monolithic vitrified HLW will be in 151 liters in a stainless steel canister (Gowing et al. 1987).

- Each canister will hold HLW from 1.9 MTU from LWR fuel or 8.65 MTU from Magnox fuel (Gowing et a1. 1987).

- Type of Spent Fuel Source and Overview Description of Spent Fuel (or Reference to Description Information)

- Current spent fuels are GCR metal fuels (uranium metal fuel clad in magnesium alloy, called Magnox fuels) with burnup of about 5 GWd/MTU, and AGR fuels (enriched uranium dioxide clad in stainless steel. The AGR fuels are $1 \mathrm{~m}$ long with a design burnup of 10-25 GWd/MTU). New future fuels will be from PWRs (Bush et a1. 1987; Schneider et al. 1988).

\section{- Out-of-Reactor Age of the Spent Fuel or Waste}

- Spent fuels are generally processed as soon as practicable, or about one year out-of-reactor for Magnox fuels, at least three years for AGR fuels, and at least five years for LWR fuels. However,

- Magnox (GCR) fuels using magnesium-clad metallic uranium are stored for about one year in the reactor pools. If more storage is needed before reprocessing, storage is carried out in air-cooled vaults for several more years because of the poor corrosion resistance of the cladding in wet storage tanks. Magnox fuels can be stored wet for only short time periods because of cladding corrosion (IEAL 1987; Bush et al. 1987).

- U.K.-produced AGR fuels are to be stored for no more than about 10 years in pools because of intergranular corrosion of the cladding. If longer storage is necessary, subsequent dry storage would be considered (Bush et al. 1987).

- LWR fuels, including those from other countries that are awaiting reprocessing are to be stored in pools until the new THORP reprocessing and vitrification facility are completed about 1992 (IEAL 1987; Bush et al. 1987). 
- HLLW is to be vitrified as soon as possible after reprocessing because of improved safety and economics for storage. However, the U.K. vitrification facility will not start up until the early 1990s, and some of their HLLW will have been stored as long as 25 years (IEAL 1987).

- Vitrified HLW will be stored until its out-of-reactor age is at least 50 years before disposal. The heat generation rate at the time of disposal is planned to be no more than about $1 \mathrm{~kW} /$ MTU (Bush et al. 1987; Passant 1987).

- For HLW:

- The 169-1iter canister will be filled with 151 liters of glass in 169-1iter canister ( $89 \%$ full) (Gowing et al. 1987).

- The age of spent fuel before reprocessing is about one year for Magnox fuels, it will be about 3 to 10 years for AGR fuels, and it will be about five to 20 years for LWR spent fuel (Bush et al. 1987).

- The age of high-level waste before disposal will be 50 to 100 years. The vitrified waste will be stored in aircooled vaults of (Parker et al. 1984; Bush et al. 1987).

- Matrix Material, if any [Composition, Original Form (e.g., Powdered Copper), and Identification of Matrixing Process]

- No matrix material is planned. Vitrified HLW will be the waste form (Gowing et al. 1987).

- Support Testing to Qualify the Haste Form

- The quality of the vitrified HLW will be based on control of process parameters (Bush et al. 1987).

3. Waste Canister (see Figure 1)

- Function(s) Provided by the Canister

- The canister will provide for containment of waste during handling, interim storage and transportation (Gowing et al. 1987).

- Design Requirements [e.g.. Life Expectancy, Temperatures, Pressures (Including Hydrostatic or Lithostatic Pressures), Meights (Including Haste Form], Criticality, Shielding]

- No information was found on the life expectancy of the canister, but the inference is that it is expected to last through the time of encapsulation in a disposal container (Woodall et al. 1987; Gowing et al. 1987). 
- The empty weight of the canister will be $85 \mathrm{~kg}$, and the total weight of canister and vitrified HLW will be about $470-485 \mathrm{~kg}$ (Woodall et al. 1987; Gowing et al. 1987).

- The full canister will have the strength to withstand extended storage when stacked $10 \mathrm{high}$, and the strength to withstand reference falls specified in IAEA transportation standards (Gowing et al. 1987).

- The maximum heat output in a canister at the time of transport will be about $2.5 \mathrm{~kW}$, and the average will be less than $2 \mathrm{~kW}$ (Gowing et al. 1987).

- Shape and Dimensions

- The shape will be cylindrical and will measure $0.43 \mathrm{~m}$ in diameter by $1.3 \mathrm{~m}$ in overall height, including the filling neck and nozzle. The stacking height will be $1.263 \mathrm{~m}$. The canister will have a reverse-dish head on bottom. Gross internal volume of the canister will be 169 liters (Gowing et a). 1987).

\section{- Hall Thickness and Corrosion Allowance}

- The canister wall thickness is assumed to be the same as for the French canister, or $5 \mathrm{~mm}$. (However, the empty weight is indicated to be about $15 \mathrm{~kg}$ heavier than the French canister) (Sombret 1985).

- The corrosion allowance is assumed to be the same as for the French canister, i.e., no corrosion allowance (Clark 1988b).

- Material of Construction

- The canister will be made of 309 staintess steel (Hough et al. 1987).

\section{- Closure Description and Process}

- The canister will have a flanged fill nozzle at its upper end, After the canister is filled with vitrified waste, the inverted hat-shaped lid will be placed loosely in the canister fill nozzle, with the flanges of the lid and nozzle mating (Woodall et al. 1987).

- Weld closure will be done by automatic fusion welding (Woodall et a]. 1987). 
- Backfilled Gases, if any

- No backfilling with special gases is expected. The gas in the canister is assumed to be air only, as in the French system (Clark 1988b).

- Handling Features

- No specific information was found on canister handling features. However, any handling features must be associated with the canister fill neck or top flange. The top flange of the canister will be recessed in the inverse bottom head when the canisters are stacked, as with the French canisters (Gowing et al. 1987).

- Final Testing and/or Support Testing to Qualify the Waste Canister

- The appearance of the final weld of the lid to the canister will be inspected visually after welding (Woodall et al. 1987).

- The final, sealed canister will be decontaminated by highpressure, water or nitric acid and monitored for external contamination (Woodall et al. 1987).

\section{Waste Disposal Container(s), if any}

- The definition of the disposal container awaits definition of the disposal environment, which will not be defined for tens of years (Schneider et al. 1988).

- Function(s) Provided by the Disposal Container

- The disposal container is expected to provide containment of waste for 500-1,000 years after disposal (Bush et al. 1987).

- Design Requirements [e.g., Life Expectancy, Temperatures, Pressures (Including Hydrostatic or Lithostatic Pressures), Weights (Including Waste Form), Criticality, Shielding]

- The thinking in the U.K. is that the disposal container should last 500-1,000 years in the disposal environment, until decay of short-lived radionuclides has occurred (Parker et al. 1984; Bush et al. 1987).

- Shape and Dimensions

- The disposal container is expected to be a cylindrical overpack of the canister. The dimensions are not yet determined (Bush et al. 1987). 


\section{- Wall Thickness and Corrosion Allowance}

- If the material of the disposal container is cast steel, about 200 mm of wall thickness is expected to last about 1,000 years in an alkaline-reducing environment (Bush et al. 1987).

\section{- Material of Construction}

- The material for the disposal container is not yet determined, but preliminary thinking is to use thin titanium-0.2\% Pd alloy or hastelloy C4 or thick cast iron or steel. The current emphasis appears to be on using thick carbon steel (Marsh et a1. 1988; Parker et al. 1984; Bush et al. 1987).

(Answers to the remaining questions on the disposal package were not found and the questions are not repeated below. It is likely that the answers are not yet developed.)

\section{Packing (or Buffer) Materials}

- Design Requirements and Function

- The preliminary thinking in the U.K. is that a packing/buffer material would provide for retardation of radionuclide transport, for control of the corrosion of the waste container(s), to provide structura] support, and for heat transfer to the host rock (Fry et al. 1982; Parker et al. 1984).

- Backfill materials would also likely be used in disposal drifts to provide structural support (Fry et al. 1982).

\section{- Materials of Construction}

- Materials to be used for packing are not yet determined, but preliminary thinking in the U.K. is that any buffer/packing material will likely be bentonite or cement. Bentonite seems to be emphasized currently (Parker et al. 1984; Marsh et al. 1988).

(Answers to the remaining questions on the packing/buffer were not found, and the questions are not repeated below. It is Tikely that the answers are not yet developed.)

\section{Repository Interface}

- Waste Package Handling, Storage, and Emplacement at Repository

- At the vitrification facility, the sealed canister of newly vitrified HLW could be placed in a transfer container and moved to the connecting vitrified waste storage facility. Interim storage of the vitrified waste will be in natural convection air-cooled vaults, with 10 canisters stacked 
vertically in each carbon steel storage tube. Cooling air will flow outside the individual storage tubes. Storage until at least 50 years out-of-reactor is planned (BNFP 1985; Woodall et al. 1987; Passant 1987; Feates 1988).

- A variety of engineering design studies on repository concepts was carried out in the U.K. in the late 1970s and early 1980 s, but no specific reference repository concept was selected, because the concept depends on the host geology (Fry et al. 1982).

- Transport of the vitrified HLW canisters will be by rail and special ship in casks that will hold 21 canisters in seven channels of three canisters end-to-end, separated by an aluminum basket. The cask overall dimensions of the case will be about $2.4 \mathrm{~m}$ in diameter (including integral fins) by $5.5 \mathrm{~m}$ long, and the cask will weigh about 110 MT. The cask will be made of medium-strength carbon steel, with a single carbon steel lid. Except for vertical loading and unloading, the cask will be handled horizontally using trunnions (Gowing et al. 1987).

- The preliminary repository concept would use emplacement of waste containers in vertical boreholes from tunnel floors if the repository is in crystalline rock, or emplacement directly in tunnels if the repository is in argillaceous rock or salt (Fry et al. 1982; Parker et al. 1984; CEC 1985).

- The in-floor concept in granite would use 0.7 -m-diameter boreholes from the floors of tunnels that are about $300 \mathrm{~m}$ deep. The emplacement boreholes would be up to $300 \mathrm{~m}$ deep with up to 97 canisters in a borehole.

- The in-room concepts in granite, clay and salt would use emplacement drifts that are three to four feet in diameter at a depth of 250-300 m below the surface.

- Packing Handling and Enplacement

- No information was found on packing handling and emplacement.

- Design Limits/Constraints by Repository (e.g., Dimensions, Heights, Temperatures, Areal Heat Loads, etc.)

- The maximum temperature at the disposal container/buffer interface is expected to be about $90^{\circ} \mathrm{C}$ (Marsh et al. 1988).

- The depth of the repository is expected to be at least $300 \mathrm{~m}$ (BNFL 1985). 
- Emplacement drifts are expected to be about 3.5 m across (BNFL 1985).

- Dimensions and Spacing of Holes in Host Rock

- In the one in-floor concept in granite, the emplacement boreholes would be on 52-m centerline distances (CEC 1985).

- Description of Liner of Holes in Host Rock, if any

- No information was found relative to liners of emplacement boreholes.

- Sealing Materials for the Emplacement Holes and How Emplaced

- No information was found relative to sealing of emplacement boreholes.

- Retrievability Provisions, if any

- No requirements have been set at this time for retrievability of waste from a repository (IEAL 1987).

- Monitoring Provisions in Emplacement Holes, if any

- No requirements have been developed regarding monitoring within the emplacement holes (IEAL 1987).

- A lengthy pre-closure monitoring period is planned for in the preliminary concept to emphasize confidence in the repository (Parker et al. 1984). 
. 
APPENDIX

GLOSSARY 


\section{APPENDIX}

\section{GLOSSARY}

The set of definitions of selected terms used in this study is given in this glossary. Except where identified otherwise, generalized definitions were taken from, Consultation Draft, Site Characterization Plan, Yucca Mountain Site, Nevada Research and Development Area, Nevada, Report DOE/RW0160 , Volume 7, "Glossary and Acronyms, " January 1988. In some cases (specifically identified), the definitions from this reference were taken from another DOE/OCRWM document, or otherwise derived for use in this report.

access drift A drift that connects the mains and the perimeter drifts, delineating the waste emplacement panels and providing access to the waste emplacement drifts.

actual retrieval period

as low as reasonably achievable (ALARA)

backfill material or backfill

barrier

borehole

borosilicate glass
The time required to retrieve the emplaced waste from the underground facility. For design purposes, this period is 34 years in the U.S.

As low as reasonably achievable taking into account the state of technology, and the economics of improvements in relation to benefits to the public health and safety, other societal and socioeconomic considerations, and the utilization of atomic energy in the public interest.

(1) The general fill that is placed in the excavated areas of the underground facility.

(2) The material or process used to refill an excavation.

Any material or structure that prevents or substantially delays movement of water or radionuclides.

A hole made with a drill, auger, or other tools for exploring strata in search of minerals, supplying water for blasting, emplacing waste, proving the position of old workings or faults, or releasing accumulations of gas or water. Boreholes include core holes, dry-wellmonitoring holes, waste-emplacement boreholes, and test holes for geophysical or ground-water characterization.

A silicate glass containing at least five percent boric acid and used to solidify commercial or defense highlevel waste. 
buffer or

packing

burnup

cask

canister

cladding (of

fuel element)

closure

(of repository)

closure

(of container)

containment

barriers

containment

period
The material that is placed in the waste emplacement hole in the annular space between a canister or overpack (if one is present) and the host rock. The packing is a component of the waste package that serves to control the release of radionuclides from the waste package by sealing against water, modifying the water chemistry, sorbing or retarding the transport of radionuclides, or by establishing other improvements in environmental parameters. (An example is a mixture of bentonite clay and crushed rock placed in the annulus between the overpack and host rock.) (from DOE/RW-0164)

A measure of nuclear-reactor fuel consumption expressed either as the percentage of fuel atoms that have undergone fission or as the amount of energy produced per unit weight of fuel.

A receptacle that holds one or more fuel assemblies, canisters, or disposal containers and provides shielding for highly radioactive materials during transportation or storage or transfer to another containment system.

As used in this document, a canister is the initial metal receptacle in which solid radioactive waste is placed for transport to the repository. In the U.S., the canister is not intended to meet the 300- to 1000-yr containment requirements of 10 CFR 60.113 (a)(1)(ii)(A) (see "container").

The metallic outer sheath of a fuel element, generally made of stainless steel or a zirconium alloy.

Final backfilling of the remaining open operational areas of the underground facility and boreholes after the termination of waste emplacement, culminating in the sealing of shafts.

The opening in a canister or disposal container that is used for filling it and is sealed after filling with high-level radioactive waste or spent fuel. (Author's definition)

Natural or man-made components of geologic disposal system designed to confine radioactive waste within a designated boundary.

In the U.S., the first several hundred years following permanent closure of a geologic repository when radiation and thermal levels are high, the uncertainties in assessing repository perfomance are large, and special emphas is is placed on the ability to contain wastes by waste packages within an engineered barrier system. 
cooling

(spent fuel)

decommissioning

design life

disposal

disposal

container

drift

emplacement

emp lacement

borehole

emp lacenent

borehole liner

engineered

barrier system

disposal (EBS)
Storage of fuel elements after discharge from reactors usually under water, to allow for the decay of shortlived radionuclides and hence the decrease of radioactivity and heat emission to acceptable levels. Synonymous with aging.

The permanent removal from service of surface facilities and components necessary for preclosure operations only, after repository closure, in accordance with regulatory requirements and environmental policies.

The period of time for which a structure, system, or component is designed to perform its intended function. In the U.S., the repository design life ends when the repository is of no further operational use, waste retrieval is no longer a concern, and closure and decomissioning begin.

The emplacement in a repository of high-level radioactive waste, spent nuclear fuel, or other highly radioactive material with no foreseeable intent of recovery, whether or not such emplacement permits the recovery of such waste and the isolation of such waste from the accessible environment.

The metal barrier(s) placed around the canister to meet containment performance objectives in the repository. (Derived from Draft SRD 9/87)

Horizontal, or nearly horizontal, mined passageway. The act of placing waste containers in prepared positions.

A borehole used specifically for emplacement of waste.

A sleeve placed in a vertical or horizontal borehole to prevent sloughed rock from interfering with the emplacement or removal of waste packages.

(1) The waste packages and the underground facility (per 10 CFR Part 60);

(2) The man-made components of a system designed to prevent the release of radionuclides from the underground facility or into the geohydrologic setting. The EBS includes the radioactive-waste form, radioactive-waste canisters, materials placed over and around such canisters, any other components of the waste package, and barriers used to seal penetrations in and into the underground facility (per 10 CFR Part 960). 
far field

fuel assembly

fuel

consolidation

geologic

repository

high-leve]

radioactive

waste (HLW)

host rock

hydrostatic head

intermediate-

level radioactive

(ILW), or

medium- Tevel

waste (MLW)

liner or sleeve

lithostatic pressure
That portion of the host rock surrounding the underground facility within which the thermal effects of the emplaced waste can be analyzed by considering only the areal power density without consideration of the specific geometric characteristics of the underground facility.

A single mechanical unit consisting of a number of fuel rods held together by a mechanical support structure designed to maintain proper spacing of the fuel rods and facilitate their handling.

The removal of spent-fuel rods from an assembly and repacking in a denser array (usually in a canister) to reduce the volume per metric ton of fuel.

A system that may be used for the disposal of radioactive wastes in excavated geologic media. A geologic repository includes (1) the geologic repository operations area and (2) the portion of the geologic setting that provides isolation of the radioactive waste and is located within the controlled area.

The highly radioactive material resulting from the reprocessing of spent nuclear fuel, including liquid waste produced directly in reprocessing and any solid material derived from such liquid waste that contains fission products in sufficient concentrations; and other highly radioactive material that the national authorities, consistent with existing law, determine by rule requires permanent isolation.

The geologic medium in which radioactive waste is emplaced.

The height of a column of liquid supported, or capable of being supported, by pressure at a point in the liquid. (Definition of "pressure head" in DOE/RW-0160.)

Used by the IAEA and some countries to designate radioactive waste of a lower activity level and heat waste output than high-level waste, but which still requires shielding during handling and transportation. The term is used generalily to refer to wastes not defined as either high-level or low-level (from IAEA TECDOC-264).

As related to the waste package, a metallic or nonmetallic liner that may be located in the emplacement hole to aid in the emplacement and possible retrieval of the waste. (Same definition as "sleeve" in DOE/RW-0160.)

The stress to which a rock formation is subjected by the weight of the overlying rocks in the lithosphere. 
low-level radioactive waste (LLW)

matrix or waste matrix

multibarrier system

near-field

overpack

packaging

package or waste package

packing

permanent closure

preclosure
Radioactive waste material that is not either high-level radioactive waste, spent nuclear fuel, transuranic waste, or byproduct material as defined in Section 11a(2) of the Atomic Energy Act of 1954.

The material that surrounds and contains the waste and to some extent protects it from being released into the surrounding rock and ground water. Only material within the canister (or drum or box) that contains the waste is considered part of the waste matrix.

A system of natural and engineered barriers operating independently or relatively independently, that acts to contain and isolate the waste.

That portion of the rock surrounding emplaced waste in which analysis of the thermal and thermomechanical effects of the waste must consider the specific geometric characteristics of the underground facility, including borehole size and orientation, standoff distance, drift shape dimensions and spacing, or overall layout of the facility.

Any receptacle, wrapper, box, or other structure that becomes an integral part of a radioactive waste package and is used to enclose a waste container for purposes of providing additional protection or for meeting the requirements of an acceptance or isolation criterion for a specific site. An overpack may be used to encase a damaged or contaminated waste package for which repair or decontamination is impractical.

The container, any overpacks and their contents, excluding radioactive materials and their encapsulating matrix but including absorbent material, spacing structures, thermal insulation, radiation shielding, devices for absorbing mechanical shock, external fittings or handling devices, neutron absorbers or moderators, and other supplementary equipment that surrounds the radioactive material.

See "waste package".

See "buffer".

See "closure, repository."

The period of time before and during the closure of the geologic repository. 
reference

concept

repository

system

repository

interface

retrievability

period

sleeve or liner

spent nuclear fuel

storage

transfer cask

transuranic

(TRU) waste
The current basic concept used in developing a waste package or repository concept, and used for comparison to potential alternative concepts. The reference concept may or may not becone the final concept.

The configuration of manmade features designed to act in harmony with the natural system to provide long-term containment and isolation of nuclear wastes and to provide for receipt, inspection, handling, emplacement, and potential retrieval of wastes during the operating phase (from D0E/RH-0164).

For this study, the reception and handling areas of a repository where high-level waste and/or spent fuel are received from another facility, treated or repackaged, and handled through final emplacement in the repository. (Author's definition)

The capability that is provided by the repository system-by means of design approaches, construction methods, and operating procedures--to allow waste retrieval to be performed.

The time during which emplaced waste is capable of being retrieved. For design purposes in the U.S., this period begins with emplacement of the first waste and ends 50 years thereafter at the end of the caretaker period.

As related to the waste package, a metallic or nonmetallic liner that may be located in the emplacement hole to aid in the emplacement and possible retrieval of the waste.

Fuel that has been withdrawn from a nuclear reactor following irradiation, the constituent elements of which have not been separated by reprocessing.

Retention of high-level radioactive waste, spent nuclear fuel, or transuranic waste with the intent to recover such waste or fuel for subsequent use, processing, or disposal.

A shielded enclosure for movement of highly radioactive material.

Waste containing more than 100 nanocuries of alphaemitting transuranic isotopes per gram of waste, with half-lives greater than twenty years, except for: 1) high-level radioactive wastes, 2) wastes that the DOE has determined, with the concurrence of the EPA Administrator, do not need the degree of isolation required by 
40 CFR Part 191, or 3) wastes that the NRC has approved for disposal on a case-by-case basis in accordance with 10 CFR Part 61 .

waste form

waste matrix or matrix

waste package
The radioactive waste materials and any encapsulating or stabilizing matrix.

The material that surrounds and contains the waste and to some extent protects it from being released into the surrounding rock and ground water. Only material within the canister (or drum or box) that contains the waste is considered part of the waste matrix.

The waste form and any containers, shielding, packing, and other absorbent materials immediately surrounding an individual waste container.

\section{Additional References (for Glossary):}

DOE/RH-0164. Consultation Draft, Site Characterization Plan, Reference Repos itory Location, Hanford Site, Hashington. U.S. Department of Energy, Washington, DC, Volume 9, "Glossary and Acronyms." January 1988.

IAEA TECDOC-264. Radioactive Waste Management Glossary. International Atomic Energy Agency, Vienna, Austria, 1982.

Waste Management System Requirements and Description. Oraft Revision 1, R.F. Weston, Inc., Washington, DC, September 24, 1987. 


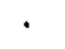




\section{REFERENCES}

Alexandre, D., M. Chotin, G. Le Blaye. 1987. "Vitrification of Fission Product Wastes: Industrial Experience and Construction of the New Vitrification Units at La Hague." In International Conference on Nuclear Fuel Reprocessing and Waste Management "RECOD 87". Paris, August 23-27, p. 289.

Baudin, G., R. Atabek, and M. Jorda. 1988. "High-Level Waste Disposal Engineered Barriers, Objectives and Results of the French R \& D Program." In Proceedings of ANS Topical Meeting, SPECTRUM ' 88 , Nuclear and Hazardous Waste Management International Topical Meeting. Richland, Washington, September 11-15, p. 214.

Baumgartner, P. and G. R. Simmons. 1987. "Disposal Centre Engineering for the Canadian Nuclear Fuel Waste Managenent Program." Radioactive Waste Management and the Nuclear Fuel Cycle, Vol. 8, Numbers 2-3, p. 219, Harwood Academic Publishers GmbH, New York.

Bechthold, W., K. D. Closs, U. Knapp and R. Papp. 1987. "Direct Disposal of Spent Nuclear Fuel". Radioactive Waste Management Series for the Commission of the European Communities, Graham and Trotman, London (approx. 125 pages)

BNFP 1985. Brochure, Nuclear Fuel Reprocessing Technology. British Nuclear Fuels plc, Risley, Warrington, U.K.

Bonne, A. and P. Manfroy. 1986. "Factors Involved in Updating the Concept of a Repository for HLW, ILW and Alpha Bearing Wastes in a Deep Clay Formation on Land." In proceedings of IAEA symposium, Siting, Design and Construction of Underground Repositories for Radioactive Wastes, Hannover, Fed. Republic of Germany, March 3-7.

Bush, R. P., R. H. Flowers, and R. K. Webster, 1987. "Selection of Strategies for the Back End of the Nuclear Fuel Cycle in the United Kingdom," In proceedings of IAEA Symposium, Back End of the Nuclear Fuel Cycle: Strategies and Options, Vienna, May 11-15.

CEC 1985. Nuclear Science and Technology, Design Study on Containers for Geological Disposal of High-Level Radioactive Waste, EUR 9909 EN, Commission of the European Communities, Brussels.

CEC 1987. "Geologic Disposal of Radioactive Waste, Annual Progress Report 1987." The Commission of the European Communities Research on Geologic Disposal of Radioactive Waste.

Clark, D. E. 1988a. "FRG, Belgium and Switzerland Information Sources on Waste Packages," Letter to K.J. Schneider (section on Belgium), Pacific Northwest Laboratory, Richland, Washington, Oecember 30, 1988. 
Clark, D. E. 1988b. "FRG, Belgium and Switzerland Information Sources on Waste Packages," Letter to K. J. Schneider (section on Federal Republic of Germany), Pacific Northwest Laboratory, Richland, Washington, December 30 , 1988.

Clark, D. E. 1988c. "FRG, Belgium and Switzerland Information Sources on Waste Packages," Letter to K.J. Schneider (section on Switzerland), Pacific Northwest Laboratory, Richland, Washington, December 30, 1988.

Feates, F. 1987. "U.K. Policy on Radioactive Waste Management." Nuclear Technology International, Sterling Publications Limited, London, p. 116.

Forsyth, R. S. and L. 0. Werme. 1987. "Corrosion Tests on Spent PWR Fuel in Synthetic Groundwater." Paper presented at the Second IAEA Research Coordination Meeting on the Performance of Solidified High-Level Waste Forms and Engineered Barriers Under Repository Conditions, Sidney, Australia, April 6-10.

Frost, C. R. 1988. "Options in Ontario Hydro's Irradiated Fuel Management Program." International Symposium on Reprocessing and Waste Management; AIChE 1988 Summer National Meeting, (Paper 64b), Denver, August 21-24.

FRG-US Workshop 3/88. "Proceedings of the Joint United States/Federal Republic of Germany Technical Exchange Conferences on Nuclear Waste March 8-11, 1988, Albuquerque, New Mexico." U.S. Department of Energy, Washington D.C.

Fry, T. M., M. J. Plews, J. A. S. Guthrie, M. C. Thorne, and M. J. Maynard. 1982. Underground Disposal of Vitrified High-Level Radioactive Waste: $A$ Review of Research and Development. U.K. Department of Environment Report No. DoE/RW/82.109, November.

Goguel, J., et al. 1987. Disposal of Radioactive Waste in Geological Formations: Technical Criteria for Site Selection. Report of the Working Group for the Ministry of Industry, Telecommunication and Tourism, France.

Gowing, R., R. D. Cheshire, M. J. 01d, I. J. Hunter, and L. G. James. 1987. Developments in High-Level Waste Transport Technology." In proceedings of IAEA Symposium, Back End of the Nuclear Fuel Cycle: Strategies and Options, Vienna, May 11-15.

Graham, J. et al. 1986. "Strength and Volume Change Characteristics of a Sand-Bentonite Buffer." In Proceedings of 2nd International Conference on Radioactive Waste Management, Canadian Nuclear Society, Winnipeg, Manitoba, Canada, September 7-11, p. 188.

Hancox, W. T. 1987. "Progress Towards a Canadian Concept for Disposal of Nuclear Fuel Waste." Paper presented at the Second IAEA Research Coordination Meeting on the Performance of Solidified High-Level Waste Forms and Engineered Barriers Under Repository Conditions, Sidney, Australia, April 6-10. 
Hancox, W. T., H. N.Isaac, and J. Howieson. 1987. "Status of the Canadian Nuclear Fuel Waste Management Programe." In proceedings of IAEA Symposium, Back End of the Nuclear Fuel Cycle: Strategies and Options, Vienna, May 11-15, p. 15.

Hancox, H. T. (AECL) Letter to C.E. Kay (U.S. DOE), October 20, 1988.

Hoorelbeke, J. M., M. Serrano, L. Chaudon, M. Cler. 1986. "Etudes Conceptuelles du Stockage des Radioactifs en Formations Geologiques Profondes." In Proceedings of IAEA Symposium, Siting, Design and Construction of Underground Repositories for Radioactive Wastes. Hannover, Fed. Republic of Germany, March 3-7.

Hough, A. and J. A. C. Marples, 1987. "Source Term Measurements on Vitrified HLH." Paper presented at IAEA Research Coordination Meeting on Performance of Solidified High-Level Waste Forms and Engineered Barriers Under Repository Conditions, Sydney, Australia, April 6-10.

IEAL 1987. Regulatory Strategies for High-Level Radioactive Waste Management in Nine Countries, IEAL-R/87-93, International Energy Associates Limited, Fairfax, Virginia, September.

Isaacs, T. H. 1988. "Report on Foreign Travel to Sweden, Germany, and France, October 18 to 26, 1988." U.S. Department of Energy, Washington, D.C.

Johnson, L. H., J. L. Crosthwaite, N. N. Gray, B. M. Ikeda, and J. C. Tait. 1987. "Engineered Barrier Research for the Canadian Nuclear Fuel Waste Management Program" in Radioactive Waste Management and the Nuclear Fuel Cycle, Vol. 8. Numbers 2-3, p. 105-143, Harwood Academic Publishers GmbH, New York.

K8S-3. Final Storage of Spent Nuclear Fuel. (KBS-3 Sumary; KBS-3 Genera) [Volume I]; KBS-3 Barriers [Volume III]), Swedish Nuclear Fuel Supply Co./Division KBS, Stockholm, May 1983.

Kempe, T. F., R. M. Zimmermann, and L. Grondin. 1987. "Radiological Assessment of Transportation of the Canadian Nuclear Fuel Haste Management Programe." In proceedings of IAEA Symposium, Back End of the Nuclear Fuel Cycle: Strategies and Options, Vienna, May 11-15, p. 304.

KfK 7/87. R \& D Programe Direct Disposal Semi-Annual Report July 11986 to December 31, 1986, KfK, Karlsruhe, Fed. Republic of Germany.

Kowalski, E., C. McCombie, and H. Issler. 1988. "Status of the Swiss Waste Disposal Projects." In proceedings of Waste Management '88, Tucson, Arizona, February 28 - March 3.

Kuhn, K. and T. Rothfuchs. 1986. "High-Level Radioactive Waste Test Disposal - Asse Salt Mine Federal Republic of Germany." In proceedings of International Topical Meeting on High-Level Nuclear Waste Disposal-Iechnology and Engineering, Pasco, Washington, September 24-26, p. 461 . 
Luckscheiter, B. 1987. "Performance of Solidified High-Level Waste Forms and Engineered Barriers Under Repository Conditions." International Atomic Energy Agency Coordinated Research Program, Vienna, April.

Lung, M., M. Alles, and A. Jouan. 1987. "High-Level Waste Vitrification: The French Industrial Program. In proceedings of ASME International Waste Management Conference, Kowloon, Hong Kong, November 29-December 5.

Marsh, G. P. and K. J. Taylor. 1988. "An Assessment of Carbon Steel Containers for Radioactive Waste Disposal," Corrosion Science, Vol. 28, No. 3, p. 289.

NAGRA 1985. Project Gewahr. Feasibility and Safety Studies for Final Disposal of Radioactive Wastes in Switzerland, NAGRA, Baden, SwitzerTand, January.

Nash, K. E. 1986. "Design and Testing of a Cask for Transporting Irradiated CANDU Fuel," In proceedings of 2nd International Conference on Radioactive Waste Management, Canadian Nuclear Society, Winnipeg, Manitoba, Canada, September 7-11.

NEA Brochure 1988. Nuclear Waste Management - Switzerland. OECD/Nuclear Energy Agency in Cooperation with NAGRA, Paris.

NEA. 1988. Information Presented at the Radioactive Waste Management Committee Meeting, Paris. Information from Belgium, Canada, France, Germany, Sweden, and Switzerland.

Nuclear Engineering International (NEI) 2/88. "Belgians Test Clay for Waste." p. 9 .

Nuttal, K. 1987. "Development of Engineered Systems for Conditioning and Disposal of Nuclear Fuel Wastes in Canada." In proceedings of IAEA Symposium, Back End of the Nuclear Fuel Cycle: Strategies and Options, Vienna, May $11-15$.

Parker, F. L., R. E. Broshears, and J. Pasztor. 1984. The Disposal of HighLevel Radioactive Waste. NAK Report No. 11, Swedish National Board for Spent Nuclear fuel (NAK), Stockholm.

Passant, F. H. 1987. "Nuclear Waste Disposal in the United Kingdom". Nuclear Europe. March-April 1987, p. 24.

Roberts, L. E. J. 1987. "Management and Disposal of Radioactive Wastes: An Overview." Nuclear Technology International, Sterling Publications Limited, London, p. 189 .

Schnidt, D. and B. Racky. 1988. "The Vitrification in the German Reprocessing Plant Wackersdorf Status of Design, Arrangement and Maintenance Concept." In proceedings of Nuclear and Hazardous Waste Managenent International Topical Meeting SPECTRUM ' 88 , Pasco, Washington, September 11-15, p. 88 . 
Schneider, K. J., L. T. Lakey, D. J. Silviera, I. W. Leigh. 1988. National Briefing Summaries: Nuclear Fuel Cycle and Waste Management, PNL-6241, Rev. 1, Pacific Northwest Laboratory, Richland, Washington, December.

Simpson, J. P., and P. H. Vallotton. 1986. Experiments on Container Materials for Swiss High-Level Waste Disposal Projects. NAGRA Technical Report 86-25, Baden, Switzerland, December.

Sombret, C. G. 1985. "The Status of French High-Level Nuclear Waste Disposal." In proceedings of the American Nuclear Society International Topical Meeting on High-Level Nuclear Waste Disposal--Technology and Engineering. Pasco, Washington, September 24-26, p. 43.

Van Iseghem, P. 1987. "The Belgian High-Level Waste Management Programme." Paper presented at the Second IAEA Research Coordination Meeting on the Performance of Solidified High-Level waste Forms and Engineered Barriers Under Repository Conditions, Sidney, Australia, April 6-10.

Van Iseghem, P. and R. De Batist. 1987. "The Interaction Between Nuclear Waste Glasses and Clay." Paper presented at the Second IAEA Research Coordination Meeting on the Performance of Solidified High-Level Waste Forms and Engineered Barriers Under Repository Conditions, Sidney, Australía, April 6-10.

Weinlander 1988. Weinlander, W. "Radioactive Waste Management in the Federal Republic of Germany." In proceedings Nuclear and Hazardous Waste Management International Topical Meeting SPECTRUM '88, Pasco, Washington, September $11-15$, p. 450 .

Woodall, A. and J. Maillet. 1987. "Solidifying Sellafield's High-Level Waste." Nuclear Engineering International, August, p. 44. 


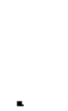




\section{DISTRIBUTION}

No. of

Copies

OFFSITE

DOE-HO

22 U.S. Department of Energy Forrestal Washington, DC 20585

D. H. Alexander, RW-332

C. S. 8amberger, GC-4I

R. J. Blaney, RW-42

J. C. Bresee, RW-10

J. H. Carlson, RW-422

R. H. Coleman, RH-422

C. R. Cooley, RW-422

M. R. Frei, RW-22

C. R. Head, RW-322

T. H. Isaacs, RW-40

H. Jaffe, IE-12

E. K. Kirkbride, DP-40

T. K. Lau, IE-12

J. M. Rooney, DP-12

S. Rousso, RW-1

J. D. Saltzman, RW-20

D. E. Shelor, RW-322

R. Stein, RW-30

14 U.S. Oepartment of Energy GTN

Washington, DC 20545

J. E. Baublitz, NE-20

K. A. Chacey, DP-123

J. A. Coleman, NE-24

J. J. Fiore, NE-23

C. H. George, DP-12

L. H. Harmon, DP-121

T. 8. Hindman, $D P-12$

J. J. Jicha, DP-123

R. H. Karlsson, DP-123

S. A. Mann, NE-22

S. P. J. Mathur, DP-123 (3)

T. W. McIntosh, NE-24
No. of

Copies
R. W. Jackson
US-DOE Representative
American Embassy
10-1, Akasaka, 1 chome
Minato-ku, Tokyo I07
JAPAN

\section{OPERATIONS OFFICE}

2 Albuquerque Operations office U.S. Department of Energy

P.0. Box 3090

Carlsbad, NM 88221

A. E. Hunt

M. McFadden

3 Chicago Operations Office U.S. Department of Energy 9800 S. Cass Avenue Argonne, IL 60439

R. C. Baker

P. M. Ferrigan

J. Haugen

S. T. Hinschberger Idaho Operations office U.S. Department of Energy 785 DOE Place Idaho Falls, ID 83402

2 Yucca Mountain Project Office U.S. Department of Energy Phase 2, Suite 200 101 Convention Center Drive Las Vegas, NV 89109

R. A. Levich

E. L. Wilmot

2 Oak Ridge Operations Office

U.S. Department of Energy Oak Ridge, TN 37831-8600

L. Clark

M. J. Rohr 
No. of

Copies

F. T. Fong

San Francisco Operations

U.S. Department of Energy

1333 Broadway

Oakl and, CA 94612

S. King

Savannah River Operations

U.S. Department of Energy

P.0. Box A

Aiken, SC 29801

E. Maestas

West Valley Project Office

U.S. Oepartment of Energy

P.0. Box 191

West Valley, NY 14171-0191

10 Office of Scientific and Technical Information

P.0. Box 62

Oak Ridge, TN 37830

\section{DOE CONTRACTORS}

2 Argonne National Laboratory Special Projects Office 9700 S. Cass Avenue

Argonne, IL 60439

S. L. Marcum

M. J. Steindler, CMT-205

W. W. Henoch

Argonne National Laboratory Special Projects Office

1 Bank Street, Suite 250

Gaithersburg, MD 20878

R. A. Nathan

Nuclear Systems Group

Battelle Memorial Inst.

$505 \mathrm{King}$ Avenue

Columbus, OH 43201
No. of

Copies
A. Van Luik
Battelle Pacific Northwest
Laboratories
Washington office
370 L'Enfant Plaza
Promenade
Suite 900
Washington, DC 20024-2115
P. Colombo
Brookhaven National Laboratory Upton, NY 11973
2 C. Ozaki
Idaho National Engineering Laboratory
EG\&G Idaho, Inc.
P.0. Box 1625
Idaho Falls, ID 83415
J. C. S. Long
Lawrence Berkeley Lab
Earth Sciences Division
1 Cyclotron Road
Berkeley, CA 94720
L. D. Ramspott, L204
Lawrence Livermore National Laboratory
University of California
P.0. Box 808
Livermore, CA 94550
D. T. Oakley, MS-J521
Los Alamos National Laboratory
P.0. Box 1663
Los Alamos, NM 87545
6 Oak Ridge National Lab
Oak Ridge, TN 37381
A. G. Croff
L. R. Dole
P. T. Owen
T. H. Row
J. H. Saling
Central Res. Library 
No. of

Copies

E. R. Naimon

Rockwell International Corp.

Rocky Flats Plant

P.0. Box 464

Golden, C0 80402-0464

3 Sandia National Laboratories

P.0. Box 5800

Albuquerque, NM 87185

R. W. Lynch

J. E. Stiegler

L. D. Tyler

8. G. Kitchen

Westinghouse Savannah River Co. Savannah River Site

Aiken, SC 29808-000I.

2 Science Applications International, Corp.

101 Convention Center Dr. \#407

Las Vegas, NV 89109-2005

E. Hardin

U. Park

W. C. Moffit

Westinghouse Electric Corp.

P.0. Box 2078

Carlsbad, NH 88220

J. R. Berreth

Westinghouse Idaho Nuclear

Co., Inc.

P.0. Box 4000

Idaho Falls, ID 83403

2 Weston

$955 L^{\prime}$ Enfant Plaza

8th Floor

Washington, DC 20024

J. F. Strahl

Technicat Information Center

J. M. Pope

West Valley Nuclear

Services Inc.

P.0. Box 191

West Valley, NY 14171-0191
No. of

Copies

\section{OTHER FEDERAL AGENCIES}

2 U.S. Environmental Protection Agency

401 M Street SW

Washington, DC 20460

F. L. Gaipin

W. H. Holcolmb

6 U.S. Nuclear Regulatory Commission Washington, DC 20555

R. M. Bernero, MS 6A-4

R. E. Browning, MS $4 \mathrm{H}-3$

J. C. Mckinley, MS H-1016

M. R. Peterson, MS $3 \mathrm{H}-5$

H. B. Schechtor

H. L. Thompson, MS 6A-4

F. L. Parker, MRS Commission

Box 1596

Station B

Vanderbilt University

Nashville, TN 37235

D. Deere

Nuclear Waste Technical Review Board

6834 SW 35th Way

Gainsville, FL 32608

\section{OTHER AGENCIES}

R. F. Williams

Electric Power Research Institute

P.0. Box 10412

3412 Hillview Avenue

Palo Alto, CA 94304

M. E. Wacks

University of Arizona

Dept. of Nuclear \&

Energy Engineering

Tucson, AZ 85721 
No. of

Copies

FORE IGN

S. Orlowski

Commission of the European

Communities

200 Rue de la Loi

1049 Brussels

BELGIUM

D. J. Squires

International Atomic Energy Agency

Waste Management Section

P.0. Box 200

Vienna

AUSTRIA - EUROPE

2 OECD Nuclear Energy Agency

38 Boulevard Suchet

75016 Paris

FRANCE

D. A. Galson

J.-P. Olivier

F. A. Goldner

U.S. Mission to OECD

c/o U.S. Embassy - Paris

APO New York, NY 09777

M. Katz

U.S. Mission to International Organizations in Vienna

Obersteinergasse 11-1

A-1190 Vienna

AUSTRIA - EUROPE
No. of

Copies

ONSIJE

5 DOE Richland Operations

M. J. Furman

D. E. Trader

E. C. Norman

S. M. Prestwich

J. C. Peschong

6 Westinghouse Hanford $\mathrm{Co}$.

D. E. Clark

H. F. Daugherty

R. L. Miller

P. S. Schaus

J. E. Tarcza

D. D. Wodrich

27 Pacific Northwest Laboratory

D. J. Bradley

J. M. Creer

P. Doctor

A. B. Johnson, Jr.

M. R. Kreiter

L. T. Lakey

I. W. Leigh

J. L. McElroy

G. W. McNair

Y. Onishi

K. J. Schneider (10)

S. C. Slate

Publishing Coordination

Technical Report Files (5) 